\title{
A PROLINEMIA COMO UM FATOR DE SEVERIDADE NA INFECÇÃO CAUSADA PELO Trypanosoma cruzi
}

Tese apresentada ao Programa de PósGraduação em Parasitologia do Instituto de Ciências Biomédicas da Universidade de São Paulo, para obtenção do Título de doutor em Ciências. 
SANDRA CARLA ROCHA

\section{A PROLINEMIA COMO UM FATOR DE SEVERIDADE NA INFECÇÃO CAUSADA \\ PELO Trypanosoma cruzi}

Tese apresentada ao Programa de PósGraduação em Parasitologia do Instituto de Ciências Biomédicas da Universidade de São Paulo, para obtenção do Título de doutor em Ciências.

Orientador: Prof. Dr. Ariel Mariano Silber

Versão corrigida. A versão original eletrônica encontra-se disponível tanto na Biblioteca do ICB quanto na Biblioteca digital de teses e dissertações (BDTD). 
DADOS DE CATALOGAÇÃO NA PUBLICAÇÃO (CIP)

Serviço de Biblioteca e Informação Biomédica do

Instituto de Ciências Biomédicas da Universidade de São Paulo

reprodução não autorizada pelo autor

Rocha, Sandra Carla.

A prolinemia como um fator de severidade na infecção causada pelo Trypanosoma cruzi / Sandra Carla Rocha. -- São Paulo, 2015.

Orientador: Prof. Dr. Ariel Mariano Silber.

Tese (Doutorado) - Universidade de São Paulo. Instituto de Ciências Biomédicas. Departamento de Parasitologia. Área de concentração:

Biologia da Relação Patógeno-Hospedeiro. Linha de pesquisa:

Metabolismo de aminoácidos em tripanossomatídeos.

Versão do título para o inglês: The prolinemia as a serverity factor in the infection caused by Trypanosoma cruzi.

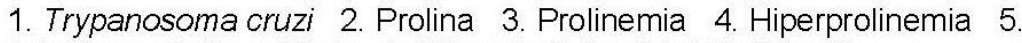
Infecção 6. Severidade I. Silber,Prof. Dr. Ariel Mariano II.

Universidade de São Paulo. Instituto de Ciências Biomédicas.

Programa de Pós-Graduação em Biologia da Relação Patógeno-

Hospedeiro III. Título. 


\begin{abstract}
Candidato(a):
Sandra Carla Rocha.

Título da Tese:

A prolinemia como um fator de severidade na infecção causada pelo Trypanosoma cruzi.
\end{abstract}

Orientador(a):

Prof. Dr. Ariel Mariano Silber.

A Comissão Julgadora dos trabalhos de Defesa da Tese de Doutorado, em sessão pública realizada a considerou

\title{
( ) Aprovado(a)
}

( ) Reprovado(a)

\begin{tabular}{|c|c|}
\hline Examinador(a): & $\begin{array}{l}\text { Assinatura: } \\
\text { Nome: ....... } \\
\text { Instituição: }\end{array}$ \\
\hline Examinador(a): & $\begin{array}{l}\text { Assinatura: } \\
\text { Nome: ....... } \\
\text { Instituição: }\end{array}$ \\
\hline Examinador(a): & $\begin{array}{l}\text { Assinatura: } \\
\text { Nome: ....... } \\
\text { Instituição: }\end{array}$ \\
\hline Examinador(a): & $\begin{array}{l}\text { Assinatura: } \\
\text { Nome: ....... } \\
\text { Instituição: }\end{array}$ \\
\hline Presidente: & $\begin{array}{l}\text { Assinatura: } \\
\text { Nome: ....... } \\
\text { Instituição: }\end{array}$ \\
\hline
\end{tabular}




\section{CerTIFICADO}

Certificamos que o protocolo registrado sob $n^{\circ} \mathbf{8 6}$ nas fls. 106 do livro 02 para uso de animais em experimentação, sob a responsabilidade do Prof(a) $\operatorname{Dr}(a))$ Ariel Mariano Silber, Coordenador(a) da Linha de pesquisa "A prolinemia como fator de virulência na infecção experimental pelo Trypanossoma cruzi" do qual participam o(s) alunos Sandra Carla Rocha, Higo Fernando Santos Souza, está de acordo com os Princípios Éticos de Experimentação Animal adotado pela Sociedade Brasileira de Ciência de Animais de Laboratório (SBCAL) e foi aprovado pela COMISSÃO DE ÉTICA NO USO DE ANIMAIS (CEUA) em 29.06.2011, com validade de 3 anos.

São Paulo, 30 de junho de 2011.
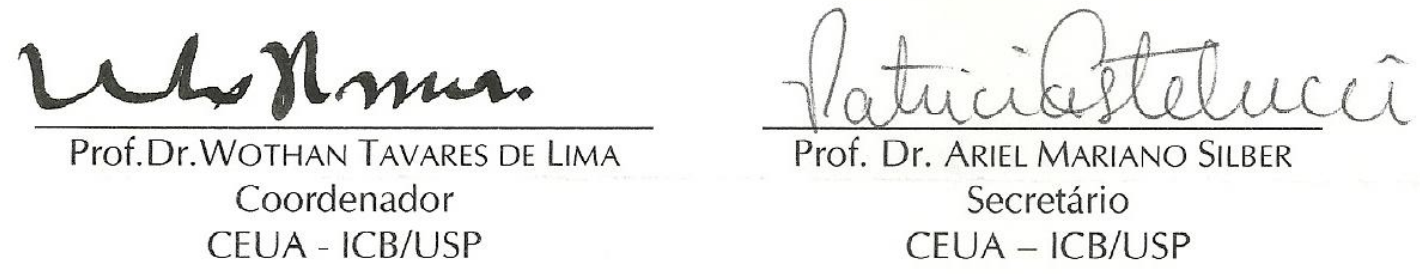


\section{REF.: Protocolo $n^{0}$ 086/11.}

"A prolinemia como fator de virulência na infecção experimental pelo Trypanosoma cruzi"

Prezado Professor,

Informo que a sua licença para uso de animais em experimentação, constante no protocolo em epígrafe, foi prorrogada até 29.06.2017.

Reitero que havendo alteração de metodologia e inserção de novos alunos ao projeto de pesquisa vinculado à referida licença a CEUA/ICB deverá ser informada.

\section{Cordialmente,}

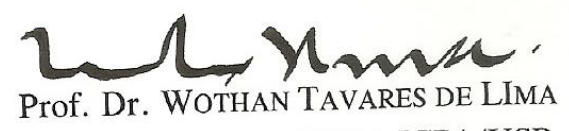

Coordenador - CEUA-ICB/ /USP

Ilmo.Sr.

Prof: Dr. Ariel Mariano Silber

Departamento de Parasitologia

Instituto de Ciências Biomédicas - USP 


\begin{tabular}{c} 
UNIVERSIDADE DE SÃO PAULO \\
INSTITUTO DE CIÊNCIAS BIOMÉDICAS \\
Cidade Universitária “Armando de Salles Oliveira" \\
$\begin{array}{c}\text { Av. Prof. Lineu Prestes, } 2415 \text { - Cep. 05508-900 São Paulo, SP - Brasil } \\
\text { Telefone :(55) (011) 3091.7733 -e-mail: cep@icb.usp.br } \\
\text { COMISSÃO DE ÉTICA NO USO DE ANIMAIS }\end{array}$ \\
\hline
\end{tabular}

Decl. CEUA. 082.14.

D E C L A R A Ç Ã O

Em adendo ao Certificado 086/2011/CEUA, datado de 29.06.11, prorrogado a validade até 29.06.17 e por solicitação do Prof. Dr. Ariel Mariano Silber, responsável pela linha de Pesquisa, autorizo a inclusão de 90 camundongos da linhagem C57BL/6 e 90 camundongos da linhagem PRO/ReJ, ao Projeto de Pesquisa "A prolinemia como fator de virulência na infecção experimental pelo Trypanossoma cruzi", uma vez que se trata de utilização da mesma espécie animal e de métodos experimentais similares ao Projeto.

São Paulo, 13 de novembro de 2014.

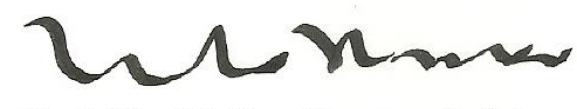

Prof. Dr. Wothan Tavares de Lima

Coordenador da CEUA

ICB/USP 
Trabalho realizado com auxílios financeiros concedido pelo Conselho Nacional de Desenvolvimento Científico e Tecnológico (CNPq), Instituto Nacional de Biotecnologia Estrutural e Química Medicinal em Doenças Infecciosas (INBEQMeDI) e Fundação de Amparo à Pesquisa do Estado de São Paulo (FAPESP). 
Aos meus pais, pelo cuidado e amor incondicional durante toda a minha vida... 


\section{AGRADECIMENTOS}

Ao Prof. Dr. Ariel Mariano Silber pela orientação, amizade, carinho, mas especialmente pela confiança depositada em mim.

Ao Higo pela intensa cooperação e, sobretudo por sua linda amizade e conselhos.

À Beth pelo suporte técnico, disposição, amizade, conselhos e por ter compartilhado de sua experiência.

Aos colegas do laboratório Alexandre, Brian, Carol, Gustavo, Flá Dama, Juli, Letícia, Ludmila, Marcell, Raíssa, Richard, Rodolfo pela ajuda, sugestões nos experimentos, discussão de resultados e, sobretudo pela amizade.

Ao grupo do Prof Carsten em especial a Flá Zimbres, Jasmin, Kamila e Thales, que cooperaram com equipamentos e reagentes.

Aos Professores Dr. Oscar Bottasso, Dra Ana Rosa Pérez e Dr. Juan Beloscar da Facultad de Ciências Médicas de Rosario por cederem amostras de soros de pacientes chagásicos. Agradeço especialmente ao Dr. Oscar que me recebeu em seu laboratório e a Dra. Ana que me deu todo o suporte para as análises de prolinemia.

Ao Prof. Dr Claudio Pereira e Melisa Sayé da Universidade de Buenos Aires que nos cederam os parasitas transfectados e, sobretudo pela amizade.

À Sandra Alexandre que cooperou massivamente com esse trabalho na recuperação e ampliação da colônia dos camundongos nocautes. Agradeço também por sua amizade e conselhos.

Aos demais colegas do departamento de Parasitologia-ICB (USP), professores, funcionários e colegas que também colaboraram com equipamentos, com sugestões, discussões e amizade.

À minha grande amiga Raíssa, por todos os momentos vividos em sua companhia.

Aos meus queridos pais, simplesmente por me amarem.

Ao meu futuro esposo Luis Cesarino pelo companheirismo, pelos conselhos, pela paciência em momentos de muito choro e também pelo apoio financeiro.

À FAPESP pela bolsa e suporte para essa pesquisa, e também ao CNPQ e à USP. 
“Todos querem o perfume das flores, mas poucos sujam as suas mãos para cultivá-las" Augusto Cury 


\section{RESUMO}

Rocha SC. A prolinemia como um fator de severidade na infecção causada pelo Trypanosoma cruzi. [tese (Doutorado em Parasitologia)]. São Paulo: Instituto de Ciências Biomédicas, Universidade de São Paulo; 2015.

Foi demonstrado que a L-prolina é fundamental para o metabolismo das formas intracelulares de T.cruzi e está envolvida em processos de resistência a diferentes condições de estresse. $\mathrm{O}$ ácido L-tiazolidina-4-carboxílico (T4C) age como inibidor competitivo do transporte de prolina para o interior do parasita, desta forma, pode-se assumir que, quando aplicado como agente terapêutico simula uma situação de hipoprolinemia no hospedeiro mamífero. Sobre esta base, propomos que a prolinemia poderia estar relacionada com a severidade da infecção pelo $T$. cruzi, portanto, decidimos inverter o racional e obter nesse trabalho um modelo de hiperprolinemia. Inicialmente foi estabelecido um modelo murino de hiperprolinemia transiente. Camundongos da linhagem $\mathrm{BALB} / \mathrm{c}$ que foram tratados com prolina, por via intraperitonial (i.p), em 30 minutos já apresentaram concentrações plasmáticas de 1,359 \pm 0,121 mM, porém, após 3 horas seus níveis plasmáticos retornaram ao normal, 0,4361 \pm 0,03496. Utilizando este modelo, foi avaliado o efeito da "hiperprolinemia transiente" em camundongos infectados pelo T.cruzi. Em três ensaios de um total de seis foi observado um aumento significativo da parasitemia em camundongos tratados, sem nenhuma diferença na mortalidade e na carga parasitária de diversos tecidos. Essa inconsistência observada no perfil da parasitemia redirecionou os experimentos para um modelo de hiperprolinemia hereditário previamente estabelecido. Interessantemente, foram observados diminuições na parasitemia, porém, a mortalidade foi aumentada. Foi hipotetizado que, diferentemente do que acontece com a hiperprolinemia transiente, com os níveis plasmáticos aumentados de maneira estável, as formas intracelulares de T.cruzi teriam acesso ao aminoácido em quantidades e tempo maiores. No entanto, não se pode descartar como hipótese complementar, que a hiperprolinemia possa afetar a resposta imune e por sua vez, imunossuprimir ou imunoestimular o hospedeiro mamífero. Por esse motivo, avaliaram-se alguns parâmetros da resposta imune ex vivo. Ensaios ex vivo mostraram que tratamento com prolina diminui a produção de NO sob ativação por LPS, no entanto quando células peritoneais não ativadas por LPS são infectadas por T. cruzi, o tratamento com prolina não altera o perfil de NO. A expressão gênica da óxido nítrico sintase induzível (iNOS) das células peritoneais diminui quando elas são cultivadas na presença de prolina, confirmando esses resultados. Mostrou-se dessa maneira que a hiperprolinemia pode interferir com a resposta imune do hospedeiro, o que levaria a uma eventual imunossupressão. Observou-se que, tanto células peritoneais infectadas como não infectados tratadas com prolina apresentam redução de seu volume celular o que poderia ser indício de sinal apoptótico. Ensaios de infecção (ex vivo) em células peritoneais de camundongos BALB/c com tripomastigotas da cepa MJL superexpressando o transportador de prolina apresentaram aumento da taxa de infecção enquanto que as infectadas por tripomastigotas da cepa Y superexpressando o mesmo transportador de prolina apresentaram diminuição da taxa de infeçção, quando comparadas aos controles, mostrando que a reposta de redução ou aumento da taxa de infecção ao tratamento com prolina é determinada também pela cepa de T. cruzi. Análises da prolinemia em soro de pacientes com sintomas de cardiopatia chagásica severa mostraram menores níveis de prolina sérica quando comparados aos controles (pacientes não infectados). Juntos, todos esses resultados colocam a prolina como um fator de severidade na infecção pelo T. cruzi.

Palavras-chave: Trypanosoma cruzi. Prolina. Hiperprolinemia. Severidade 


\begin{abstract}
Rocha SC. The prolinemia, as a severity factor in the infection caused by Trypanosoma cruzi. [Ph. D. Thesis (Parasitology)]. São Paulo: Instituto de Ciências Biomédicas, Universidade de São Paulo; 2015.

It was shown that L-proline is essential for the metabolism of the intracellular forms of $T$. cruzi and is involved in resistance to different stress conditions. L-thiazolidine-4-carboxylic acid (T4C) acts as a competitive inhibitor of the proline transport to the inside of parasite, thus it can be assumed that when $\mathrm{T} 4 \mathrm{C}$ is applied as a therapeutic agent simulates a hipoprolinemia situation in the mammalian host. On this basis, we propose that prolinemia could be related to the severity of $T$. cruzi infection, then, in this work we decided to reverse the rational and obtain a hyperprolinemia model. As a starting point, it was established a mouse transient hyperprolinemia model. BALB/c mice were intraperitoneally injected with proline showed an increased proline levels in sera after $30 \mathrm{~min}(1,359 \pm 0,121 \mathrm{mM})$. However, these increased levels were diminished to normal levels after $3 \mathrm{~h}(0,4361 \pm 0,03496 \mathrm{mM})$. Once established this model, was initially used to evaluate the effect of "transient hyperprolinemia" in mice infected by T.cruzi. In three out of six experiments an increase in parasitemia but not in mortality or in tissue parasite loads was observed. In the remaining three experiments no differences were detected. These inconsistencies directed the work to the search to a previously established hereditary model of mouse hyperprolinemia model. Interestingly, in this new model, a diminished parasitemia was recorded, however, mortality was higher. From this information it was hypothesized that, differently to what happens in the transient hyperprolinemia, a permanent hyperprolinemia exposes the T. cruzi infected cells (and so, the intracellular parasites) to higher concentrations of proline as well as for longer times. In addition, it cannot be disregarded the complementary hypothesis that hyperprolinemia could be affecting the immune response and, at the same time of its action on the parasite, it could be immunosupresing or immunostimulating the mammalian host. This possibility led us to evaluate some parameters of the immune response both, in vivo and ex vivo. Ex vivo assays showed that proline-treated LPS-activated peritoneal cells had a diminished production of NO while proline-treatment of $T$. cruzi infected, non-LPS-activated peritoneal cells did not affect their NO production. This data showed that hyperprolinemia could interfer the immune response leading the host to an eventual immunosupresion. In addition, both, infected and non-infected macrophages had their cellular volume diminished when treated with proline, which could be attributed to the iniciation of an apoptotic process. Infection assays (ex vivo) of perioneal cells from BALB/c mice with MJL strain trypomastigotes overexpressing a proline transporter had an increased infection rate, while the same type of cells infected with Y strain trypomastigotes overexpressing the same proline transporter showed a diminution in the infection rate. These results show that changes in the infection rate as a function of intracellular proline availability depends on $T$. cruzi strain. The analysis of prolinemia in patient's serum with symptoms of Severe Chronic Chagasic Cardiopathy showed tat proline levels were diminished in comparison to control (non-infected patients). Taken together, these results prompt proline as a factor modulating the severity of $T$. cruzi infection.
\end{abstract}

Keyword: Trypanosoma cruzi. Proline. Hyperprolinemia. Severity 


\section{LISTA DE FIGURAS}

Figura 1 - Distribuição geográfica da doença de Chagas

Figura 2 - Representação esquemática do ciclo de vida do Trypanosoma cruzi.

Figura 3 - Evolução parasitológica e sorológica na doença de Chagas.

Figura 4 - Via metabólica da L-prolina em mamíferos.

Figura 5 - Evolução dos níveis de prolina no plasma e na urina em camundongos.

Figura 6 - Monitoramento dos níveis de prolina plasmática após sua 51 administração oral.

Figura 7 - Evolução do peso corporal durante e após o tratamento com prolina por via i.p.

Figura 8 - Picos parasitêmicos de animais infectados e tratados com prolina.

Figura 9 - Curvas de sobrevida de animais infectados e tratados com prolina.

Figura 10 - Avaliação da carga parasitária tecidual por meio de técnica histológica.

Figura 11 - Avaliação da carga parasitária tecidual por meio de PCRq.

Figura 12 - Efeito da suplementação de prolina no estágio intracelular de $T$. cruzi em células peritoneais

Figura 13 - Área celular $\left(\mu^{2}\right)$ de células peritoneais infectadas.

Figura 14 - Área celular $\left(\mu \mathrm{m}^{2}\right)$ de células peritoneais não infectadas.

Figura 15 - Curva de regressão linear construída a partir de diferentes concentrações de nitrito $\left(\mathrm{NO}_{2}^{-}\right)$produto indireto da geração de óxido nítrico.

Figura 16 - Produção de óxido nítrico por células peritoneais cultivadas com prolina.

Figura 17 - Produção de óxido nítrico por células peritoneais cultivadas na presença de prolina e arginina.

Figura 18 - Efeito da suplementação de prolina no meio de cultura sobre a viabilidade de células peritoneais. 
Figura 19 - Curvas de regressão linear utilizando diferentes primers murinos.

Figura 20 - Expresão gênica de iNOS em células peritoneais cultivadas com diferentes concentrações de LPS.

Figura 21 - Expressão gênica de mediaores pró- e anti-inflamatórios em células peritoneais cultivadas com diferentes concentrações de prolina.

Figura 22 - Efeito da suplementação de prolina no estágio intracelular das cepas MJL e Y de $T$. cruzi que superexpressam o transportador de prolina TcAAAP069, em células peritoneais.

Figura 23 - Acompanhamento da curva de parasitemia em fêmeas de 72 camundongos da linhagem BALB/c infectados pela cepa $Y$ superexpressora do transportador de prolina TcAAAP069.

Figura 24 - Curvas de sobrevida de fêmeas de camundongos da linhagem BALB/c infectados pela cepa $Y$ superexpressora do transportador de prolina TcAAAP069.

Figura 25 - Acompanhamento da parasitemia em camundongos da linhagem C57BL/6 infectados e tratados com prolina.

Figura 26 - Acompanhamento da sobrevida de camundongos da linhagem C57BL/6 infectados e tratados com prolina.

Figura 27 - Esquema de cruzamento para seleção de camundongos mutantes PRO/ReJ.

Figura 28 - Genotipagem da geração $\mathrm{F} 2$ para seleção de camundongos mutantes PRO/ReJ.

Figura 29 - Concentração de prolina plasmática em camundongos PRO/ReJ.

Figura 30 - Acompanhamento da parasitemia em camundongos machos 78 PRO/ReJ.

Figura 31 - Acompanhamento da parasitemia em camundongos fêmeas 78 PRO/ReJ.

Figura 32 - Picos da curva parasitêmica de camundongos PRO/ReJ e 79 heterozigóticos infectados pela cepa Y de $T$. cruzi.

Figura 33 - Curvas de sobrevida de PRO/ReJ fêmeas e machos infectados pela 79 cepa Y de $T$. cruzi.

Figura 34 - Concentração de prolina sérica em pacientes chagásicos.

Figura 35 - Variações relativas das atividades dos transportadores de glicose e prolina e concentrações de prolina intracelular livre durante o ciclo de vida 
do $T$. cruzi.

Figura 36 - Representação esquemática sugerida para os efeitos antagônicos do metabolismo da prolina na célula do hospedeiro mamífero sobre infecção pelo T. cruzi. 


\section{LISTA DE TABELAS}

Tabela 1 - Picos parasitêmicos de animais infectados e tratados com prolina.

Tabela 2 - Carga parasitária tecidual de animais infectados pelo T. cruzi e tratados com prolina.

Tabela 3 - Valores de inclinação da curva, $\mathrm{Y}$ na origem e $\mathrm{R}^{2}$ obtidos com a construção da curva-padrão utilizando primers específicos para actina- $\beta$, IL-10, TGF- $\beta$ e TNF- $\alpha$ murinos.

Tabela 4 - Dados estatísticos dos níveis de prolina sérica em pacientes chagásicos que possuem ou não cardiopatia.

Tabela 5 - Parâmetros farmacocinéticos da prolina e doses administradas de acordo com a idade de ratos Wistar. 


\section{LISTA DE ABREVIATURAS}

\begin{tabular}{|c|c|}
\hline$\mu \mathrm{g}$ & Micrograma \\
\hline$\mu l$ & Microlitro \\
\hline$\mu \mathrm{m}$ & Micrômetro \\
\hline$A N O V A$ & Análise de variância \\
\hline ATP & Adenosina trifosfato \\
\hline ACT- $\beta$ & Actina- $\beta$ \\
\hline ARG & Arginina \\
\hline $\mathrm{BZ}$ & Benzonidazol \\
\hline $\mathrm{CCC}$ & Cardiomiopatia chagásica crônica \\
\hline $\mathrm{CD}$ & Cluster of differentiation (Conjunto de diferenciação) \\
\hline cDNA & DNA complementar \\
\hline $\mathrm{CHO}_{-} \mathrm{K}_{1}$ & Linhagem celular proveniente de ovário de hamster Chinês \\
\hline $\mathrm{CO}_{2}$ & Dióxido de carbono \\
\hline $\mathrm{Ct}$ & Threshold cycle (Ciclo limiar de detecção) \\
\hline d.p.i & Dias após a infecção \\
\hline DEPC & Dietilpirocarbonato \\
\hline $\mathrm{DL}_{50}$ & Dose-Letal $50 \%$ \\
\hline DMEM & Meio para cultura celular (Dulbecco's Modified Eagle's médium) \\
\hline DNA & Ácido desoxirribonucléico \\
\hline DNAg & DNA genômico \\
\hline DNase & Desoxirribonuclease \\
\hline dNTP & Desoxirribonucleosídeo trisfosfato \\
\hline DO & Densidade ótica \\
\hline DTT & Ditiotreitol \\
\hline $\mathrm{EC}$ & Enzyme Comission (Comissão de nomenclatura de enzimas) \\
\hline EDTA & Ácido etilenodiaminotetracético \\
\hline FAD & Flavina-adenina dinucleotídeo \\
\hline g & gramas \\
\hline$g$ & gravidade \\
\hline GLU & Glutamato \\
\hline GSA & Glutamato semi-aldeído \\
\hline $\mathrm{H}$ & Heterozigótico \\
\hline $\mathrm{H} \& \mathrm{E}$ & Hematoxilina e eosina \\
\hline $\mathrm{HCl}$ & Ácido clorídrico \\
\hline HP & Hiperprolinemia \\
\hline $\mathrm{IC}_{50}$ & Concentração inibitória de $50 \%$ dos organismos \\
\hline i.p & Intraperitoneal \\
\hline IFN- $\beta$ & Interferon-beta \\
\hline $\mathrm{IFN}-\gamma$ & Interferon-gama \\
\hline $\operatorname{IgG}$ & Imunoglobulina $\mathrm{G}$ \\
\hline $\operatorname{IgM}$ & Imunoglobulina $\mathrm{M}$ \\
\hline IL & Interleucina \\
\hline iNOS & Óxido nítrico sintase induzível \\
\hline $\mathrm{KCL}$ & Cloreto de potássio \\
\hline $\mathrm{Kg}$ & Kilogramas \\
\hline $\mathrm{KO}$ & Nocaute \\
\hline $\mathrm{L}$ & Litros \\
\hline LIT & Liver Infusion-Tryptose \\
\hline
\end{tabular}




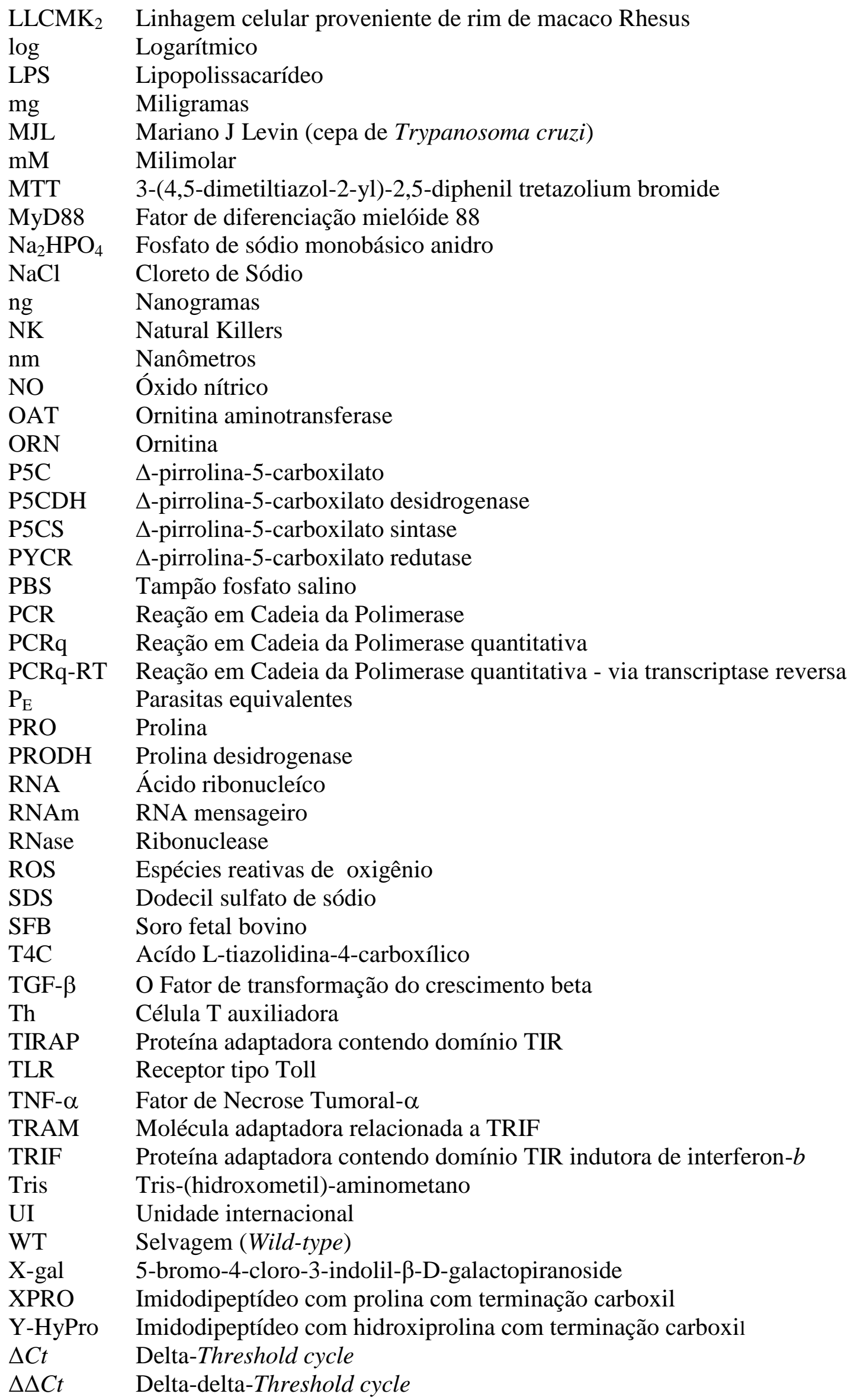




\section{SUMÁRIO}

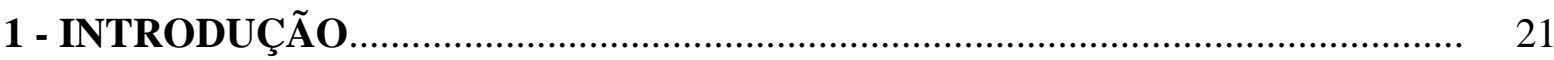

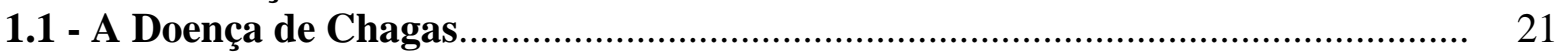

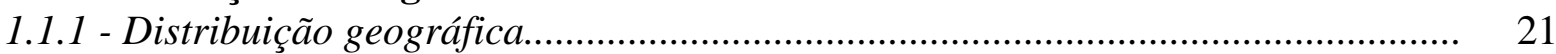

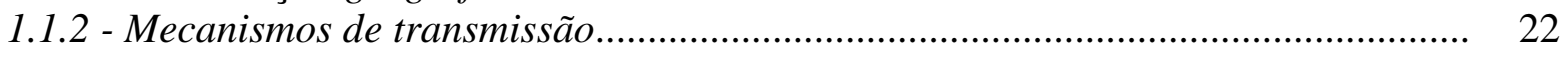

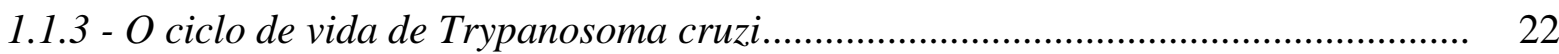

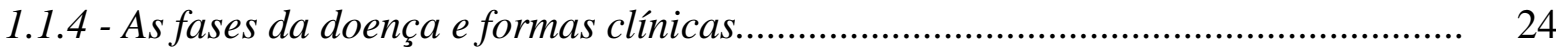

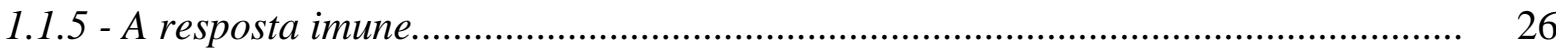

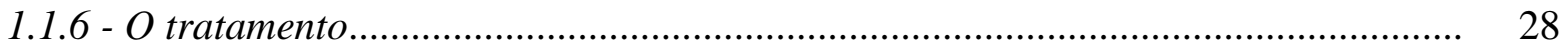

1.2 - Os aminoácidos na biologia do Trypanosoma cruzi............................................... 29

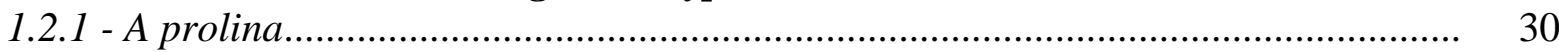

1.3 - Metabolismo de prolina em mamíferos........................................................ 31

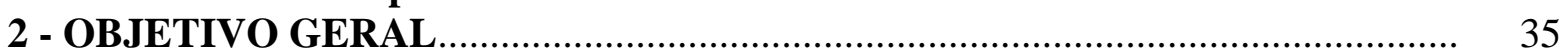

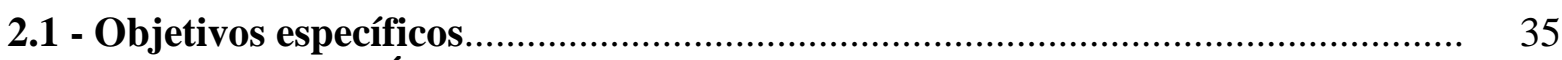

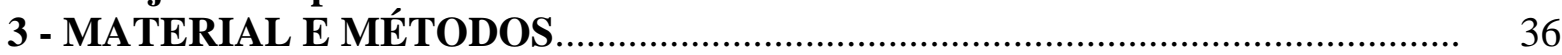

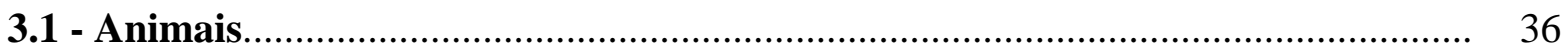

3.2 - Obtenção e validação do modelo experimental de hiperprolinemia................... 36

3.2.1 - Desenho experimental.................................................................................. 36

3.2.2 - Determinação dos níveis de prolina no plasma e na urina.................................... 37

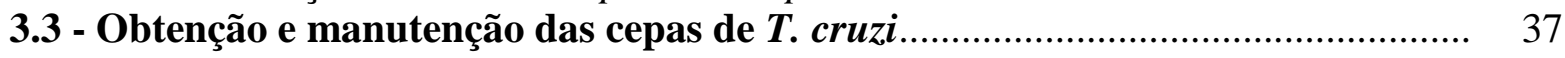

3.3.1 - Formas tripomastigotas sanguícolas...................................................................... 37

3.3.2 - Formas tripomastigotas provenientes de infecçôes in vitro................................... 37

3.3.3 - Formas epimastigotas..................................................................................... 38

3.4 - Obtenção e manutenção das cepas de $T$. cruzi transfectadas com TcAAAP069 e GFP.

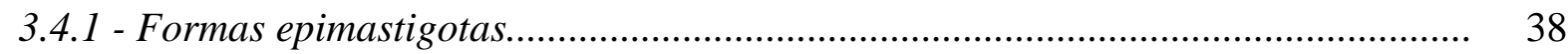

3.4 .2 - Formas tripomastigotas provenientes de infecções in vitro.................................. 38

3.4.3 - Formas tripomastigotas sanguícolas................................................................ 39

3.5 - Infecção e tratamento com prolina.................................................................... 39

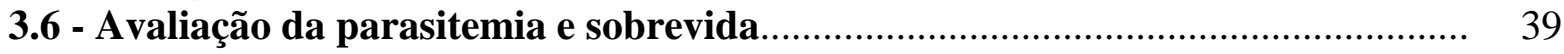

3.7 - Análise da carga parasitária tecidual............................................................... 39

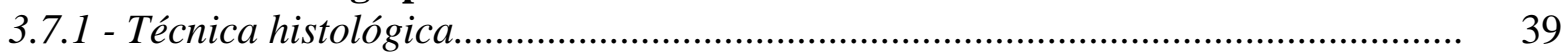

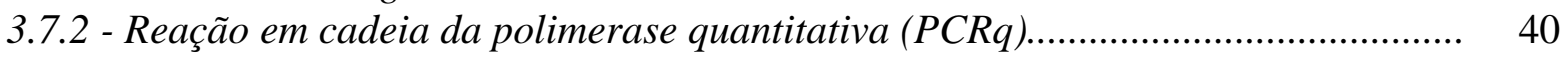

3.8 - Obtenção de células peritoneais..................................................................... 41

3.9 - Cultivo de células peritoneais para dosagem de óxido nítrico............................. 42

3.9.1 - Dosagem de óxido nítrico.................................................................................. 42

3.10 - Cultivo de células peritoneais para teste de toxicidade................................... 42

3.11 - Cultivo de células peritoneais para avaliação da expressão gênica de mediadores pró- e anti-inflamatórios, utilizando PCR $\boldsymbol{q}$........................................... 43

3.11 .1 - Extração de RNA de células peritoneais............................................................. 43

3.11 .2 - Síntese de cDNA a partir de RNA de células peritoneais....................................... 44

3.11 .3 - Teste de eficiência dos primers iNOS, IL-10, TGF- $\beta$, TNF- $\alpha$ e ACT- $\beta$ (actina-

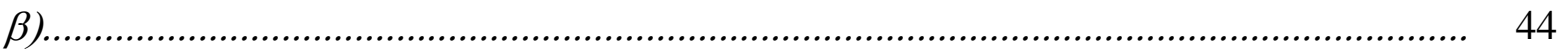

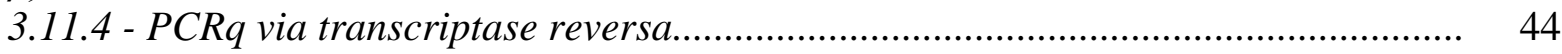

3.11.5 - Tratamento dos dados de PCRq-RT............................................................... 45

3.12 - Cultivo de células peritoneais para ensaio de infecção.................................. 45

3.13 - Determinação da área citoplasmática de células peritoneais.......................... 46

3.14 - Avaliação da prolinemia em pacientes chagásicos.......................................... 46 
3.15 - Obtenção de camundongos PRO/ReJ e expansão da colônia............................. 46

3.15.1 - Seleção de camundongos PRO/ReJ por genotipagem........................................ 47

3.16 - Ensaio de infecção em camundongos PRO/ReJ.............................................. 48

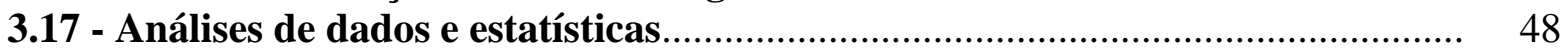

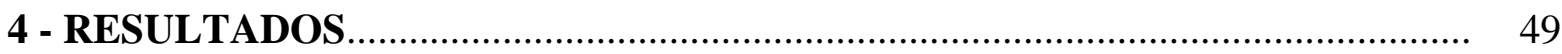

4.1 - Construção de um modelo de hiperprolinemia............................................... 49

4.2 - Efeito da hiperprolinemia transiente sobre a severidade da infecção em camundongos

4.3 - Efeito da suplementação de prolina no meio de cultura sobre o ciclo

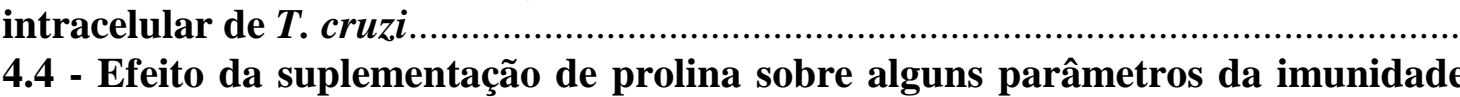
inata de células peritoneais.

4.5 - Efeito da prolina sobre o ciclo intracelular de cepas de $T$. cruzi suprerexpressoras do transportador de prolina e sobre a infecção in vivo...

4.6 - O modelo genético de hiperprolinemia e os efeitos da infecção pelo $T$. cruzi...

4.7 - A prolinemia pode estar relacionada à severidade da sintomatologia de pacientes chagásicos?

5 - DISCUSSÃ̃o.

5.1 .

5.2 - O efeito da hiperprolinemia sobre a severidade da infecção pelo $T$. cruzi.......... 85

5.3 - O efeito da suplementação de prolina ex vivo no estágio intracelular de $T$.

cruzi.

5.4 - A prolina e seu papel na imunidade do hospedeiro mamífero................................ 88

5.5 - O transporte de prolina em $T$. cruzi.............................................................................. 89

5.6 - O modelo genético de hiperprolinemia: Camundongos PRO/ReJ........................ 90

5.7 - Prolinemia versus severidade da infecção.............................................................. 92

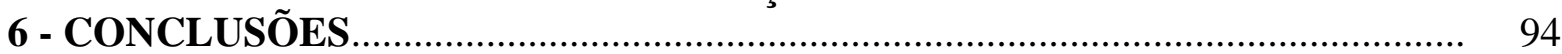

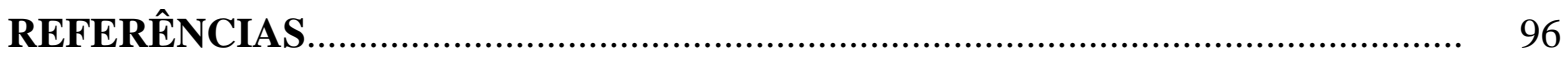




\section{INTRODUÇÃO}

\subsection{A doença de Chagas}

A doença de Chagas, ou tripanossomíase americana, é uma infecção crônica e sistêmica causada pelo protozoário hemoflagelado Trypanosoma cruzi, descoberta pelo médico brasileiro Carlos Chagas em 1909 (Chagas, 1909). Classicamente, o protozoário enquadra-se no filo Sarcomastigophora, subfilo Mastigophora, na ordem Kinetoplastida e família Trypanosomatidae, no entanto, um novo esquema de classificação taxonômica foi proposto para eucariotos por Adl et al. (2005). Os autores propõe a inclusão do T. cruzi dentro do super-grupo Excavata (antigamente reino Protista) e dentro desse grupo é classificado, seguindo a ordem hierárquica, como Euglenozoa, Kinetoplastea, Metakinetoplastina e Trypanosomatida (Adl et al., 2005).

\subsubsection{Distribuição geográfica}

A doença é endêmica em 21 países e se distribui nas Américas desde o sul dos Estados Unidos até o sul da Argentina e do Chile. De acordo com a World Health Organization (WHO, 2012) cerca de 8 milhões de pessoas estão cronicamente infectadas com T. cruzi na América Latina, ocorrendo por volta de 12 mil mortes por ano. A doença também ocorre em países não endêmicos como Canadá, Austrália, Japão, Espanha, França, Itália, Suécia, Suíça e Reino Unido devido à imigração de pessoas infectadas provenientes de regiões endêmicas (Rassi et al., 2012).

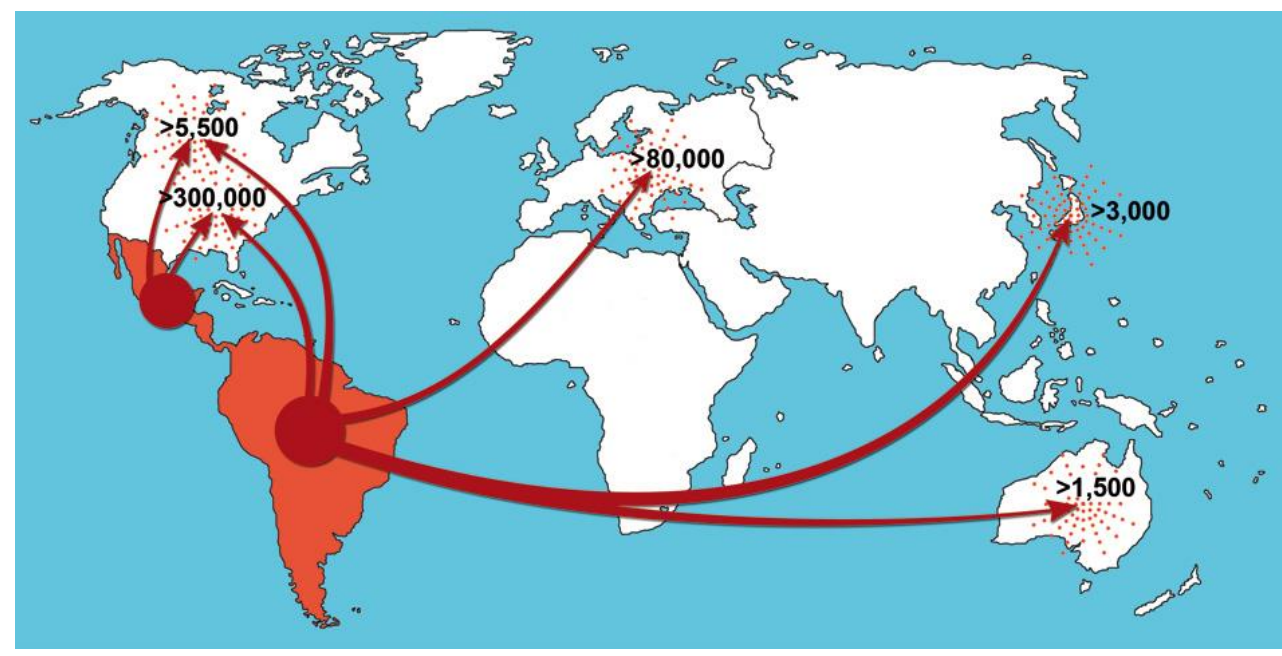

Figura 1 - Distribuição geográfica da doença de Chagas nas áreas endêmicas e as rotas de migração de pacientes infectados desde a América Latina com o número total estimado de indivídos infectados em regiões não endêmicas (Coura e Viñas, 2010). 


\subsubsection{Mecanismos de transmissão}

A doença é transmitida para os humanos e para mais de 150 espécies de pequenos mamíferos através do artrópode vetor da ordem Hemiptera e família Reduviidae. As principais espécies de vetores que transmitem a infecção a seres humanos são Triatoma infestans, Triatoma brasiliensis, e Panstrongylus megistus nos países do cone Sul, Rhodnius prolixus e Triatoma dimidiata nos países andinos e em partes da América Central e por último, Triatoma dimidiata e Triatoma barberi no México (Piccinali et al., 2009). A doença também pode ser transmitida por mecanismos não vetoriais. A transmissão por transfusão sanguínea (Mazza et al., 1936), via congênita (Bittencourt, 1976; Hoff et al., 1978) e por transplantes de órgãos (Schmunis, 2007) são as formas mais frequentes em regiões não endêmicas (Coura, 1966; Coura, Viñas, 2010; Dias, 1945; Schmunis, 2007; Strasen et al., 2014). Acredita-se que a transmissão oral é a forma mais frequente entre animais silvestres, uma vez que pequenos mamíferos se alimentam de insetos com frequência na natureza. Em regiões endêmicas a transmissão oral em humanos também é bastante frequente devido à comercialização e ingestão de alimentos contaminados com restos de triatomíneos contendo as formas infectivas de T.cruzi (Benchimol-Barbosa, 2009; Rassi et al., 2010). Uma forma de transmissão pouco comum é por acidentes de laboratório. Essa via é epidemiologicamente pouco relevante já que está restrita a pesquisadores e profissionais da saúde que trabalham em contato direto com a forma infectiva de T.cruzi.

\subsubsection{O ciclo de via de Trypanosoma cruzi}

Trypanosoma cruzi possui um ciclo de vida que envolve um inseto vetor da família Reduvidae e um hospedeiro mamífero (eventualmente o homem) (Chagas, 1909). O inseto infecta-se ao picar um hospedeiro mamífero que possui formas tripomastigotas circulantes no sangue. Os tripomastigotas ingeridos pelo inseto vetor alcançam a porção média do tubo digestivo onde se diferenciam em epimastigotas, formas replicativas não infectantes. Os epimastigotas, sob estresse metabólico, iniciam um novo processo de diferenciação que começa pela sua adesão ao epitélio intestinal. Essas formas aderidas se diferenciam em formas tripomastigotas metacíclicas (formas não replicativa, infectivas) (Bonaldo et al., 1988) que são liberadas do epitélio intestinal e eliminadas junto com as fezes durante o seguinte repasto sanguíneo do inseto. Uma vez depositados na pele do mamífero, os tripomastigotas internalizam-se no hospedeiro (através das mucosas ou pela lesão da picada), invadem as suas células, e atingem o citoplasma. Nesse local, se diferenciam em amastigotas, estágio 
replicativo no interior do hospedeiro mamífero. Após vários ciclos de divisão binária, os amastigotas diferenciam-se para formas tripomastigotas passando de maneira transiente por um estágio denominado epimastigota intracelular (Almeida-De-Faria et al., 1999). Finalmente, os tripomastigotas lisam as células e são liberados ao meio extracelular, podendo invadir outras células vizinhas, ou atingir a corrente sanguínea, e através dela os tecidos distantes. Fecha-se o ciclo quando as formas tripomastigotas circulantes são ingeridas por um novo inseto vetor (Alves, Colli, 2007; Tyler, Engman, 2001) (Figura 2).

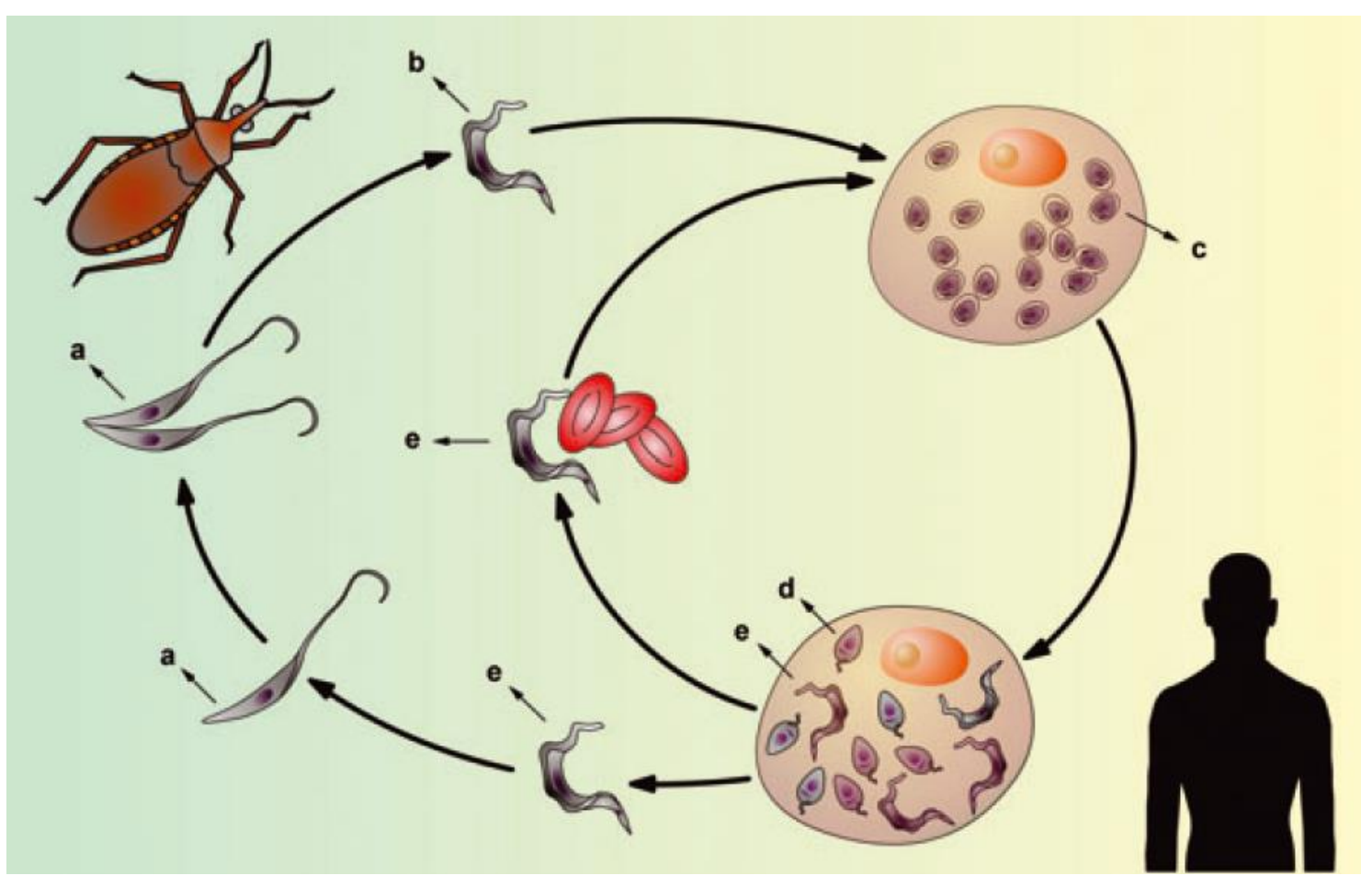

Figura 2 - Representação esquemática do ciclo de vida do Trypanosoma cruzi. (a) formas epimastigotas (replicativas) (b) formas tripomastigotas metacíclicas (infectivas). (c) formas amastigotas (replicativas). (d) formas epimastigotas intracelular. (e) formas tripomastigotas (infectivas). Fonte: Boscardin et al., (2010).

\subsubsection{As fases da doença e formas clínicas}

A infecção humana pelo T. cruzi divide-se em duas fases: aguda e crônica. A fase aguda caracteriza-se por uma alta parasitemia, leucócitos e células subcutâneas infectadas, edema intersticial, infiltração linfocística, hiperplasia reativa dos linfonodos adjacentes, altos níveis de anticorpos IgM circulantes e baixa produção de IgG. Com o tempo os parasitas disseminan-se pelo sistema linfático e corrente sanguínea, encontrando-se na maioria dos tecidos principalmente músculos e gânglios. A partir desse momento inicia-se a segunda etapa 
da doença, a fase crônica. Esta se caracteriza por um baixo ou nulo número de parasitas circulantes e uma robusta resposta humoral (Figura 3) (revisado por Rassi et al., 2012).

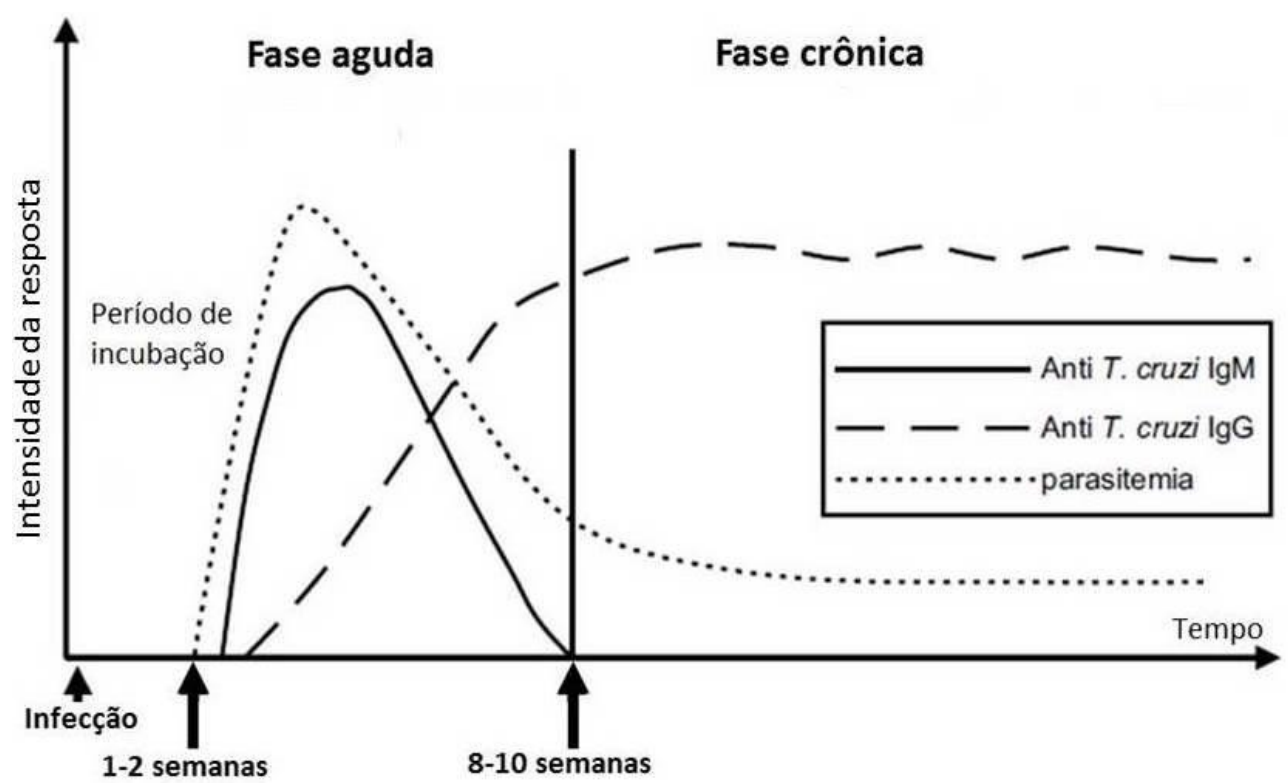

Figura 3 - Evolução parasitológica e sorológica na doença de Chagas. A fase aguda em humanos dura aproximadamente dois meses, do qual é caracterizada por intensa parasitemia, altos níveis de anticorpos IgM, baixos níveis de IgG com seu aumento progressivo no decorrer das ultimas semanas. Com a resolução da fase aguda, a parasitemia torna-se extremamente baixa e os níveis de $\operatorname{IgG}$ atingem seu nível máximo, prolongando-se por toda a vida (modificado a partir de Rassi et al., 2012)

\section{(a) Fase aguda}

$\mathrm{Na}$ maioria dos indivíduos, a fase aguda da doença de Chagas é assintomática ou apresenta sintomatologia inespecífica. Geralmente em humanos os sintomas aparecem por volta do $8^{\circ}$ ao $10^{\circ}$ dia após a infecção ou do $20^{\circ}$ ao $40^{\circ}$ dia em casos de contaminação por transfusão sanguínea. Os sintomas inespecíficos observados são febre prolongada, hepatoe/ou esplenomegalia, linfadenomegalia, edema subcutâneo localizado ou generalizado. Na transmissão vetorial, há sinais de porta de entrada de T. cruzi: o chagoma de inoculação (via cutânea) e o sinal de romaña (via ocular). Sintomas neurológicos e miocardite severa não são comuns na fase aguda, no entanto ocorre ocasionalmente meningoencefalite. A taxa de mortalidade varia entre 5 a $10 \%$ principalmente em crianças menores de 2 anos. Durante esta fase a doença pode ser detectada por exame direto de sangue fresco por meio de microscópio ou PCR, e também por hemocultura ou xenodiagnóstico. Com a evolução da doença, o sistema imune induz a redução da carga parasitária com subsequente controle do balanço 
parasita/hospedeiro (Chatelain, 2015; Dubner et al., 2008; Kirchhoff, 2011; Murcia et al., 2013; Pereira, Navarro, 2013; Rassi et al., 2010, 2012)

\section{(b) Fase crônica}

A fase crônica se inicia entre 2 e 3 meses após o início da infecção. Cerca de 60 a 70\% dos indivíduos infectados apresentam a forma indeterminada da doença, caracterizada por ausência de sintomas clínicos. O restante (30 a 40\%) apresenta alguma das formas sintomáticas, caracterizada principalmente por cardiopatia e/ou distúrbios digestivos (megaesófago e megacólom). Geralmente os sintomas aparecem quando a doença já está bem estabelecida, de 10 a 30 anos após o inicio da infecção (revisado por Rassi et al., 2010, 2012).

A cardiomiopatia chagásica crônica (CCC) é uma patologia inflamatória que afeta cerca de $30 \%$ dos indivíduos sintomáticos. Aproximadamente um terço dos pacientes com CCC desenvolvem uma forma letal de cardiomiopatia com disfunção ventricular, falência cardíaca e arritmia. A severidade clínica é correlacionada com a ocorrência da miocardite (CunhaNeto, Chevillard, 2014; Higuchi et al., 1987), sendo que uma miocardite difusa com foco de infiltrado inflamatório e dano da fibra cardíaca, fibrose proeminente e baixa carga parasitária é o que caracteriza a CCC do miocárdio (Cunha-Neto et al., 2009).

A forma digestiva da doença de Chagas é caracterizada por alterações das funções motoras, secretórias e absortivas do esôfago e do trato gastrointestinal Tais distúrbios digestivos, denominados maegaesófago e/ou megacólon, afetam de 10 a $15 \%$ dos pacientes cronicamente infectados. O megaesófago causa principalmente disfagia e regurgitação (revisado por Rassi et al., 2010) enquanto que o megacólon causa constipação, meteorismo e discinesia. Na maioria dos casos, ambas manifestações estão associadas. Lesões do sistema nervoso entérico e a consequente redução do número de neurônios são responsáveis pela evolução das megasíndromes (Adad et al., 1991; Koberle, 1968). Particularente o megaesófago é caracterizado por enlargamento do lúmen e hipertrofia muscular. A ocorrência frequente de ganglionite em pacientes com manifestações de megaesófagos indica a participação de células dos sistemas imune na patologia da doença (da Silveira et al., 2005). 


\subsubsection{A resposta imune}

Cada fase exibe características e mecanismos imunológicos distintos, sendo que o controle da infecção na fase aguda depende primariamente da resposta inata, enquanto que, a fase crônica depende de uma potente resposta humoral, a ativação de células T CD4, CD8+ e a produção de citocinas, processos que em conjunto estão envolvidos no controle da doença. A ausência de alguns destes componentes da resposta imune leva o hospedeiro vertebrado a maior suscetibilidade à infecção pelo $T$ cruzi, resultando em maiores taxas de parasitemia e mortalidade (Abrahamsohn, Coffman 1996; revisado por Boscardin et al., 2010; Kumar, Tarleton 1998; Rottenberg et al., 1993a,b; Tarleton et al., 1992, 1996).

$\mathrm{Na}$ imunidade inata alguns padrões moleculares associados a patógenos (PAMPs) derivados de T. cruzi são reconhecidos por receptores específicos do hospedeiro, os receptores Toll (TLR) (Campos, Gazzinelli, 2004). As vias de sinalização deste receptor podem ser reguladas pelo fator de diferenciação mielóide 88 (MyD88), pela proteína adaptadora contendo domínio TIR (TIRAP), pela proteína adaptadora contendo domínio TIR indutora de interferon- $\beta$ (TRIF) e pela molécula adaptadora relacionada a TRIF (TRAM) (Takeda, Akira 2007). O papel das vias de sinalização de TLR na resistência a T.cruzi é baseado em observações de camundongos nocautes. De acordo com a literatura, camundongos KO TLR-9 e TLR-9/2 apresentam diminuição da resposta IL-12 e IFN- $\gamma$, que os torna mais suscetíveis a infecção por T. cruzi, sugerindo que TLR-2 e TLR-9 cooperam para controlar a replicação do T cruzi durante a fase aguda (Bafica et al., 2006). Outro componente importante da imunidade inata são as células Natural Killers (NK). Além de lisarem diretamente as células infectadas, as NKs são capazes de produzir enormes quantidades de IFN- $\gamma$, principalmente no fígado de camundongos na fase aguda da infecção, o que é conseqüência da produção de IL-12 e TNF- $\alpha$ pelas células dendríticas e macrófagos (Cardillo et al., 2007; Golgher, Gazzinelli 2004; Sardinha et al., 2006).

A resposta imune adaptativa na doença de Chagas é mediada principalmente pelos linfócitos $\mathrm{T} \mathrm{CD}^{+}$e constitui um meio efetivo de controlar a replicação do parasita (Brener, Gazzinelli, 1997). Foi mostrado também que a resposta Th1 é importante para o controle da infecção enquanto a resposta Th2 contribui para a persistência parasitária e para o aumento da severidade da doença (Tarleton et al., 2000). As células T CD $8^{+}$também exercem um papel importante no controle da infecção por T. cruzi, pois são capazes de lisar diretamente a células infectadas (Nickell et al., 1993; Wizel et al., 1997). A relevância do IFN- $\gamma$ na fase aguda da 
infecção, também está relacionada com sua capacidade de ativar macrófagos peritoniais, dentre seus inúmeros efeitos. Os macrófagos ativados são capazes de produzir óxido nítrico (NO) através da NO sintase induzível (iNOS), provocando a morte do parasita (Gazzinelli et al., 1992; McCabe, Mullins 1990; Nathan et al., 1979; Reed, 1988; Vray et al., 1991). Além de IFN- $\gamma$ outras citocinas são importantes durante a fase aguda da infecção por $T$. cruzi. Camundongos deficientes em IL-12 apresentaram maiores parasitemia e mortalidade quando comparadas com os controles, demonstrando sua relevância na infecção (Galvão Da Silva et al., 2003; Michailowsky et al., 2001). A importância da IL-10 como moduladora da infecção também foi demonstrada, já que a sua ausência reduziu a parasitemia em camundongos infectados com T. cruzi (Abrahamsohn, Coffman 1996).

Durante a fase crônica da infecção, o miocárdio de pacientes com CCC apresenta um infiltrado inflamatório com predominância de células correspondentes a uma resposta do tipo Th1, sendo composto principalmente por células $\mathrm{T} \mathrm{CD}^{+}, \mathrm{CD}^{+}$e macrófagos (Abel et al., 2001; Higuchi et al., 1993; Milei et al., 1992; Morato et al., 1998; Reis et al., 1993; Rocha Rodrigues et al., 2012). Além disso, ocorre a produção de grandes quantidades de IFN- $\gamma$ e TNF $\alpha$, por outro lado IL-4, IL-6, IL-7, e IL-15 são encontradas em pequenas quantidades no miocárdio (Abel et al., 2001; Cunha-Neto et al., 2005; Fonseca et al., 2007; Higuchi et al., 1993; Reis et al., 1993,1997; Rocha Rodrigues et al., 2012). Também observa-se em pacientes com CCC uma redução no número de células regulatórias $\mathrm{CD} 4^{+} \mathrm{CD} 25^{+}$produtoras de IL-10 (Abel et al., 2001; Araújo et al., 2007; Gomes et al., 2003) e células regulatórias $\mathrm{CD}^{+} \mathrm{CD}^{2} 5^{+}$ FoxP3 $^{+}$(da Silveira et al., 2009) em comparação com pacientes assintomáticos. Esses dados mostram que a resposta inflamatória Th1 no miocárdio sofre pouca regulação, do qual explica o dano cardíaco progressivo na CCC (revisado por Cunha-Neto, 2014). Em pacientes que apresentam a forma digestiva observa-se junto as lesões no tecido: fibrose e infiltrato inflamatório composto principalmente por células $\mathrm{T} \mathrm{CD}^{+}$e $\mathrm{CD} 4^{+}$, células citotóxicas $\mathrm{CD} 8^{+} \mathrm{e}$ TIA1 ${ }^{+}$, linfócitos B, células NKs, e macrófagos (d'Avila Reis et al., 2001).

A importância dos anticorpos também está bem demonstrada para o controle da infecção crônica por $T$ cruzi. Quando soros de pacientes chagásicos ou de camundongos foram inoculados em camundongos naïves, tanto a parasitemia quanto a mortalidade foram reduzidas após o desafio com T. cruzi (Kierszenbaum, 1980; Krettli, Brener, 1976). A resposta celular é importante para o controle inicial da infecção, no entanto, uma resposta efetiva mediada por anticorpos é crítica para o aumento da sobrevivência. 


\subsubsection{O tratamento}

Atualmente o tratamento etiológico da doença de Chagas é baseado em dois compostos nitroheterocíclicos: O Nifurtimox (3-metil-4(5'-nitrofurfurilideneamina)-tetrahidra-4 $\mathrm{H}$-1,4tiazina-1,1-dióxido) e o Benzonidazol ( $N$-benzil-2-nitro-1-imidazolacetamida) os quais foram desenvolvidos empiricamente a mais de 40 anos atrás (Cerisola et al., 1977; Ferreira, 1976). Hoje, apenas o Benzonidazol (BZ) é fabricado no Brazil por um laboratório federal e disponibilizado pelo gorverno para o tratamento de pacientes chagásicos. Ambas as drogas são efetivas contra infecções agudas e congênitas, apresentando de 60 a $80 \%$ e mais de 90\% de cura parasitológica, respectivamente (revisado por Urbina, 2010). A eficácia das drogas varia de acordo com a área geográfica, provavelmente devido às diferenças na suscetibilidade entre diferentes cepas de T. cruzi (Filardi, Brener, 1987; Urbina, 2010). Entretanto, a maior limitação dessas drogas é sua eficácia variável e limitada quando utilizada em pacientes crônicos, além de seus efeitos adversos.

BZ vem sendo extensivamente investigado em pacientes cursando a fase crônica em ensaios clínicos e por enquanto, entre todas as drogas testadas até hoje, representa a melhor opção quanto se diz respeito ao balanço eficácia e reações adversas. As recomendações segundo o Ministério da Saúde Brasil (2005) é que crianças sejam tratadas com 5 a $10 \mathrm{mg} / \mathrm{kg}$ de BZ dividida em 2 ou 3 doses diárias durante 60 dias. Para adultos, a dose diária recomendada é de $5 \mathrm{mg} / \mathrm{Kg}$, também durante 60 dias.

O mecanismo de ação do BZ envolve estresse oxidativo com modificação covalente de macromoléculas por intermediários de nitroredução, do qual inibe a síntese de RNA e proteínas em tripomastigotas metacíclicos e amastigotas (revisado por Docampo, 1990). A reação adversa mais comum é a demartite alérgica localizada e generalizada, do qual afeta entre 20 a $30 \%$ dos pacientes e geralmente começa entre o $8^{\circ}$ e $10^{\circ}$ dia após o ínicio do tratamento. Outra reação adversa que afeta entre 5\% a 10\% dos pacientes, geralmente numa fase mais tardia do tratamento, é a neuropatia periférica sensível. Leucopenia acompanhado de granulocitopenia ou agranulocitose e trombocitopenia púrpura são as reações adversas mais raras e mais graves. Náuseas, vômitos, anorexia, perda de peso, perda de paladar, insônia e onicólise são reações adversas também observadas em pacientes sob tratamento (Rassi et al., 2003, 2009). 
O mecanismo de ação do Nifurtimox não é totalmente conhecido, mas deriva de sua habilidade em formar ânions de radicais superóxido e outras espécies reativas de oxigênio, resultando em lesão da membrana celular, inativação enzimática e danos ao DNA das formas tripomastigotas e amastigotas (revisado por Docampo, 1990). O tratamento com Nifurtimox também está associado a uma série de reações adversas. Os mais comuns são sintomas gastrointestinais ocorrendo em cerca de $50 \%$ dos pacientes. O acometimento gastrointestinal inclui anorexia acompanhada de perda de peso, vômito, desconforto abdominal e ocasionalmente diarreia. Dentre as reações adversas mais comuns observa-se também toxicidade do sistema nervoso central que desencadeia em insônia, irritabilidade e desorientação. Polineuropatia, parestesia e neurite periférica são reações adversas raras, porém as mais sérias. Dor de cabeça, mialgia, artralgia, tontura ou vertigem e alteração de humor são reações adversas também observadas em pacientes sob tratamento (Rassi et al., 2003, 2009).

\subsection{Os aminoácidos na biologia do Trypanosoma cruzi}

Como já foi mencionado, $T$. cruzi apresenta um ciclo de vida que alterna em diferentes ambientes (exemplo: o trato intestinal do inseto, o sangue do hospedeiro vertebrado e o citoplasma da célula hospedeira) e a disponibilidade de metabólitos presentes nestes espaços é fundamental para sua sobrevivência. Para isso, T. cruzi, dentre outros tripanossomatídeos são capazes de utilizar carboidratos e aminoácidos como fontes de carbono e energia (Cazzulo, 1992, 1994; Silber et al., 2005).

Os epimastigotas de T. cruzi catabolizam preferencialmente glicose, no entanto, com a exaustão desse metabólito, ocorre o catabolismo de proteínas, de aminoácidos e produção de amônia (Cazzulo, 1992, 1994). As formas tripomastigotas também utilizam com preferência a glicose que é abundante nos fluídos do hospedeiro vertebrado. No hospedeiro invertebrado, a maior fonte de carbono e energia para T. cruzi são os aminoácidos, especialmente a L-prolina e a L-glutamina que são abundantes na hemolinfa e nos fluídos teciduais do inseto vetor hematófago (Cannata, Cazzulo, 1984; Fairlamb, Opperdoes, 1986). Já as formas intracelulares que residem no citoplasma da célula do hospedeiro mamífero apresentam baixa ou nula atividade de transporte de glicose, o que sugere, que sua principal fonte de energia são os aminoácidos, dentre eles prolina, que pode ser fornecida por biossíntese ou hidrólise de proteínas endógenas (no caso de amastigotas), ou até mesmo fornecida exogenamente pelo próprio hospedeiro vertebrado (no caso de epimastigotas intracelulares) (Silber et al., 2009). 
Trabalhos clássicos mostraram que asparagina, glutamina, aspartato, glutamato, leucina, isoleucina e prolina são metabolizados pelo T.cruzi (Mancilla et al., 1967; Sylvester, Krassner, 1976; Zeledon, 1960). Foi proposto que todos esses aminoácidos seriam convertidos em glutamato ou aspartato, podendo esses últimos ser desaminados e então processados via Ciclo de Krebs (Silber et al., 2005). Em T. cruzi, muitos aminoácidos estão envolvidos em diferentes funções, como síntese protéica, metabolismo energético, processos de osmorregulação (Rohloff et al., 2003, 2004) crescimento (Pereira et al., 2002) e resistência ao estresse (Pereira et al., 2003).

\subsubsection{A prolina}

Nosso grupo tem demonstrado no contexto das nossas linhas de pesquisa ou em colaboração com outros autores, que a prolina está envolvida em todos esses processos citados acima. Sabe-se que desde a década de 1970 a prolina é uma fonte oxidável, e portanto, que provavelmente, participa da produção de ATP (Sylvester, Krassner, 1976). Posteriormente foi mostrado a sua participação na metaciclogênese (Contreras et al., 1982). Mais recentemente, observou-se que esse aminoácido está envolvido na resposta ao desbalanço oxidativo (Magdaleno et al., 2009; Paes et al., 2013; Sayé et al., 2014), e na obtenção de energia para a invasão das células do hospedeiro mamífero (Martins et al., 2009). Também foi mostrada a sua relevância no sustento energético das formas intracelulares (Silber et al., 2009) e na diferenciação de epimastigotas intracelulares para tripomastigotas, processo que acontece no citoplasma das células infectadas (Tonelli et al., 2004). Por outro lado, foi descrita também a presença de uma prolina racemase (Reina-San-Martin et al., 2000) que foi posteriormente caracterizada (Chamond et al., 2003) e que parece estar envolvida na metaciclogênese (Chamond et al., 2005), o que reforça o papel de prolina ou seus derivados metabólicos na diferenciação entre estágios em T. cruzi. Também foi mostrado o mecanismo pelo qual esse aminoácido é oxidado e participa na produção de energia (Paes et al., 2013; Mantilla et al., 2015).

Em epimastigotas, o transporte de prolina acontece através de dois sistemas ativos, sendo um deles dependente do gradiente de $\mathrm{H}^{+}$da membrana plasmática e o outro dependente da hidrólise direta de ATP (Silber et al., 2002). Resultados recentes do nosso laboratório mostraram que a prolina é efetivamente oxidada a glutamato através de duas enzimas que agem de forma seqüencial: prolina desidrogenase (PRODH) (Paes et al., 2013) e $\Delta$-pirrolina5-carboxilato desidrogenase (P5CDH) (Mantilla et al., 2015). Nossos dados demonstram 
também que a PRODH participa da cadeia respiratória, constituindo uma fonte alternativa de elétrons ao complexo II (Paes et al., 2013). Nesse sentido, foi explorada a atividade tripanocida de análogos de L-prolina com especial ênfase naqueles que tivessem atividade inibitória do transporte desse aminoácido. Recentemente, Magdaleno et al. (2009), demonstraram que o ácido L-tiazolidina-4-carboxílico (T4C) inibe competitivamente o transporte de prolina em T. cruzi, diminuindo o estoque de prolina intracelular, sem efeito de inibição sobre a atividade da PRODH e prolina racemase. Além disso, T4C inibiu o crescimento de formas epimastigotas $\left(\mathrm{IC}_{50}=0,88 \mathrm{mM}\right)$ e interagiu sinergicamente com condições de estresse que o parasita sofre ao longo do seu ciclo de vida, tais como estresse térmico, nutricional, e particularmente estresse oxidativo. E finalmente, T4C diminuiu significantemente a eclosão de tripomastigotas de células $\mathrm{CHO}-\mathrm{K} 1$ infectadas por T.cruzi (Magdaleno et al., 2009).

Embora os dados de inibição da eclosão de tripomastigotas não fossem promissores, resolveu-se avaliar o efeito de T4C in vivo sob a hipótese de que na presença constante dos fatores de estresses mencionados acima, esse análogo iria ter um melhor desempenho do que nos experimentos in vitro. Os resultados obtidos confirmaram essa hipótese. Os animais tratados com dose única de 100 ou $150 \mathrm{mg} / \mathrm{kg}$ apresentaram redução da parasitemia e a carga parasitária no intestino. $\mathrm{O}$ tratamento prolongado de $10 \mathrm{mg} / \mathrm{kg}$ ao dia também diminuiu a carga parasitária no intestino, no entanto, não interferiu com a parasitemia ${ }^{1}$.

\subsection{Metabolismo de prolina em mamíferos}

O metabolismo de prolina em mamíferos, incluindo humanos, vem sendo estudado desde a década de 50 por diversos pesquisadores (Adams, 1970; Adams, Frank, 1980; Adams et al., 1958; Bertolo, Burrin, 2008; Cerra et al., 1979; Clemmons, 1966; Strecker, Mela, 1955; Phang, 1985; Phang et al., 2001, 2012; Schafer et al., 1962; Togashi et al., 2014; Wu et al 2008). A prolina pode ser derivada a partir da dieta e da degradação de proteínas endógenas e para sua liberação final é necessário a participação da enzima prolidase do qual hidroliza a ponte peptídica do anel pirrolidina. A prolina também pode ser biossintetizada a partir de glutamato e ornitina o que torna esse aminoácido nutricionalmente não essencial (Phang, 1985). Em mamíferos a prolina é degradada pelas mesmas enzimas da via de degradação em

\footnotetext{
${ }^{1}$ Sandra Carla Rocha, Dissertação de Mestrado.
} 
protozoários. A prolina desidrogenase (PRODH), a primeira enzima da via, é ligada fortemente a mebrana interna mitocondrial. O mecanismo catalítico envolve a transferência de elétrons a partir do substrato prolina ao flavina-adenina dinucleotídeo (FAD) utilizando o citocromo $c$ como transportador subsequente dentro da cadeia transportadora de elétrons (Adams, Frank, 1980; Hagedorn, Phang, 1983). O produto intermediário da degração da prolina é a $\Delta^{1}$-pirrolina-5-carboxilato (P5C). Depois a P5C-desidrogenase catalisa a conversão da P5C a glutamato (Phang, 1985) (Figura 4).

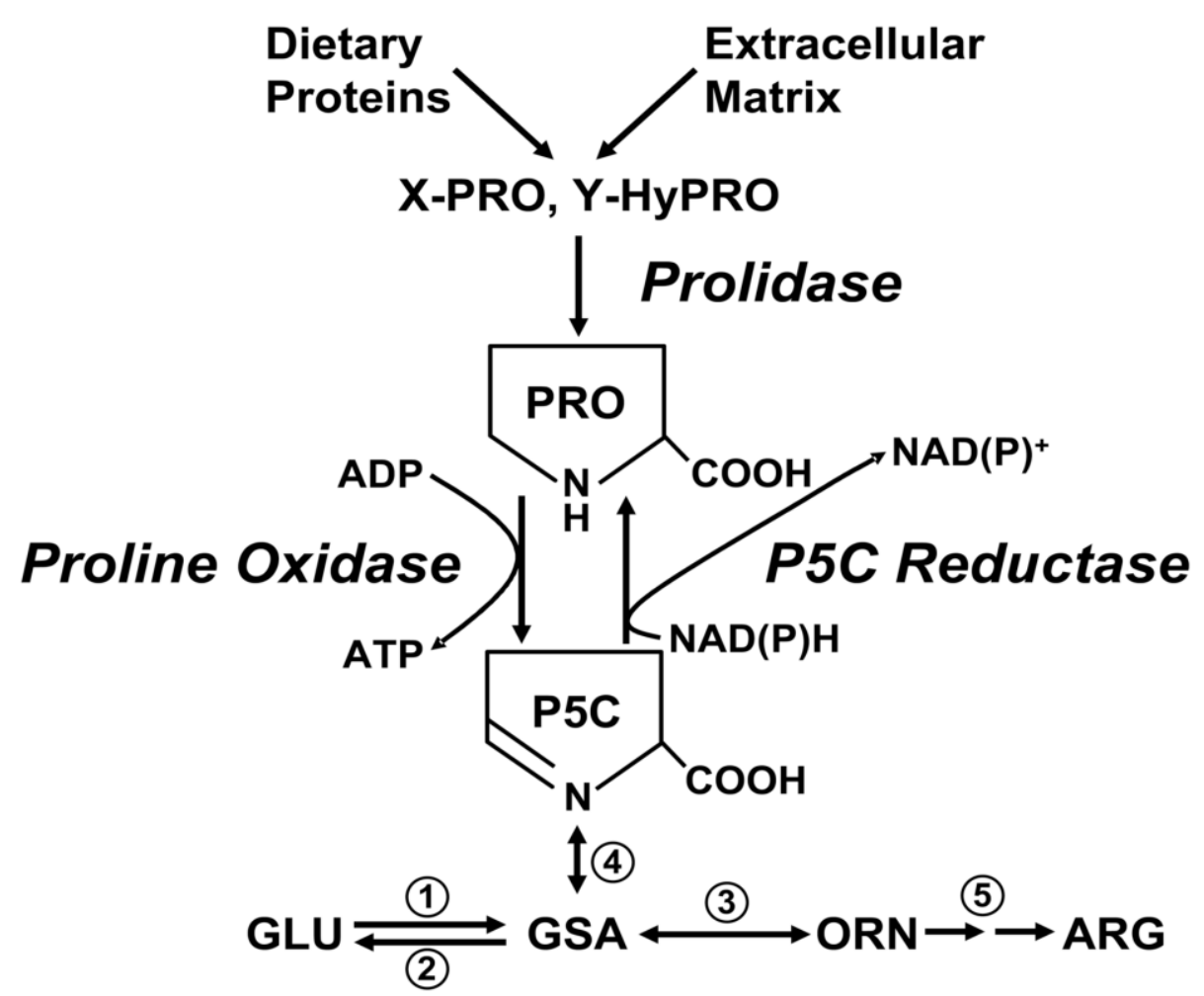

Figura 4 - Via metabólica da prolina em mamíferos: Abreviações PRO, proline; P5C, pirrolina-5-carboxilato; XPRO, imidodipeptídeo com prolina com terminação carboxil; Y-HyPro, imidodipeptídeo com hidroxiprolina com terminação carboxil; GLU, glutamato; GSA, glutamato- $\gamma$-semialdeído; ORN, ornitina; ARG, arginina. Enzimas: 1, P5C-sinthase; 2, P5C-desidrogenase; 3, ornitina aminotransferase; 4, reação espontânea; 5, enzimas do ciclo da uréia. Prolina oxidase é um nome alternativo para a prolina desidrogenase (Phang, 1985).

Apesar da prolina ser categorizada como um dos aminoácidos não essenciais em mamíferos, ela é indispensável para diversas funções. Segundo a literatura, a suplementação de prolina diminuiu a progressão das lesões coriorretinianas em pacientes com atrofia girata (Hayasaka et al., 1985), conferiu efeito imunoestimulatório em camundongos imunizados com vacina inativada de Pasteurella multocida (Ren et al., 2013), resultou em melhores taxas de 
síntese proteica no músculo, pele e intestino delgado de leitões recém-náscidos (Brunton et al., 2012), melhorou o crescimento intrauterino de porcos e ovelhas em situação de restrição de crescimento devido à doença ( $\mathrm{Wu}$ et al., 2008), além disso, mostrou atuar como neuromodulador dentro do sistema nervoso central (Sarhan, Seiler, 1989).

Há mais de 45 anos atrás, o primeiro caso do envolvimento direto da prolina com uma doença humana foi reportado por Schafer et al. (1962). Os autores descreveram a respeito de uma família apresentando disfunção cerebral, anormalidades renais, nefropatia hereditária e surdez associado a altos níveis de prolina sérica. Desordens do metabolismo da prolina em humanos são conhecidas por hiperprolinemia tipo I e tipo II; deficiência da P5C sintase, deficiência da ornitina aminotransferase (OAT), hidroxiprolinemia e iminoglicinúria (revisado por Mitsubuchi et al., 2008).

As hiperprolinemias (HPs) são desordens metabólicas autossômicas recessivas caracterizadas pelo aumento da concentração de prolina sérica. As HPs são decorrentes de deficiências genéticas de enzimas específicas que participam da via catabólica da prolina. Existem dois tipos de desordens metabólicas que afetam os níveis de prolina circulante no sangue: a HP tipo I e tipo II (revisado por Mistsubish et al., 2008). O primeiro caso hiperprolinemia foi descrito por Schafer et al. (1962). A HPI é causada pela deficiência da enzima prolina desidrogenase $(\mathrm{PRODH})$ que converte a prolina em $\Delta$-pirrolina-5-carboxílato (P5C), enquanto a HPII é devido à ausência de atividade da enzima P5C desidrogenase (P5CDH) que catalisa a degradação de P5C a glutamato, levando ao acúmulo de P5C e prolina no sangue e urina. A HPII é caracterizada por níveis ainda maiores de prolina no plasma que a HP1, e pela excreção de P5C na urina. Em um paciente normal a concentração de prolina no plasma varia de 0,05 a 0,27 mM (Phang et al., 1995) enquanto que, indivíduos acometidos por esse tipo de desordem apresentam níveis séricos que podem chegar a 2,7 mM. (Phang et al., 2001).

É interessante a escassez de relatos na literatura sobre hipoprolinemia (baixos níveis de prolina sérica). Os poucos que aparecem estão relacionados com outras doenças complexas como a de Parkinson (Pflughaupt, Brune 1971), ou colocam a HP como parte de alterações metabólicas mais complexas (Baumgartner et al., 2000). Também não há relatos de um modelo experimental deste tipo de desordem. Isto provavelmente deve-se ao fato que o metabolismo de prolina está estreitamente relacionado ao de glutamina e glutamato, cujos níveis mínimos em fluidos biológicos são fundamentais na viabilidade dos mamíferos. 
Como já foi mencionado, o T4C é o inibidor competitivo do transporte da prolina, e portanto, quando aplicado como agente terapêutico simularia uma situação de hipoprolinemia no hospedeiro mamífero. Desta maneira, decidimos inverter o racional e obter um modelo murino de hiperprolinemia, baseado na hipótese de que a prolinemia é um importante fator de severidade na doença de Chagas. 


\section{OBJETIVO GERAL}

Avaliar o efeito da hiperprolinemia no hospedeiro mamífero como possível fator de severidade na infecção causada pelo Trypanosoma cruzi.

\subsection{Objetivos específicos}

- Estabelecer um modelo experimental de hiperprolinemia em camundongos BALB/c e C57BL/6.

- Avaliar o efeito da infecção pelo Trypanosoma cruzi em camundongos hiperprolinêmicos.

- Avaliar parâmetros da resposta imune inata na infecção aguda de camundongos hiperprolinêmicos pelo T. cruzi.

- Testar a relação da severidade da infecção da doença de Chagas com a prolinemia em humanos 


\section{MATERIAL E MÉTODOS}

\subsection{Animais}

Foram utilizados camundongos isogênicos fêmeas e machos da linhagem BALB/c, C57BL/6 e os nocautes PRO/ReJ, bem como seus heterozigóticos, todos com idade entre 6 e 12 semanas. Os animais nocautes PRO/ReJ foram obtidos a partir de dois casais fornecidos pela companhia The Jackson Laboratory. Todos os animais utilizados foram produzidos e mantidos no Biotério do Departamento de Parasitologia do ICB, USP. Esses animais foram mantidos à temperatura ambiente regulada com acesso livre a ração e água (ad libitum). Todos os procedimentos laboratoriais envolvendo animais foram previamente autorizados pela comissão de ética em uso de animais para experimentação do ICB-USP (Protocolo 086, Fls 106, Livro 02).

\subsection{Obtenção e validação do modelo experimental de hiperprolinemia}

Para validação do modelo, foi avaliada a cinética de aumento e decaimento da prolinemia a níveis normais no plasma em animais que receberam diferentes doses de prolina por via intraperitoneal (i.p) ou por via oral (Moreira et al., 1989). Como parâmetro de toxicidade, foi avaliada a evolução do peso corporal de animais que receberam a dose mais alta de prolina por via i.p, durante 10 dias.

\subsubsection{Desenho experimental}

Animais da linhagem BALB/c e C57BL/6 foram tratados com prolina via i.p em doses que variam de 0,8 a 18,2 $\mu$ moles/g. A sangria foi realizada pela bochecha em diferentes tempos após o tratamento: 0 - 0,5 - 1 - 3 e 6 horas após a injeção por via i.p. As amostras de sangue, com heparina $(14 \mathrm{UI} / \mathrm{mL})$, foram centrifugadas a $1077 \mathrm{~g}, 25^{\circ} \mathrm{C}$, por 10 minutos, para obtenção do plasma. A urina também foi coletada para acompanhar a cinética dos níveis de prolina. Paralelamente, outro grupo de camundongos da linhagem BALB/c recebeu prolina $(18,2 \mu \mathrm{moles} / \mathrm{g})$ na água do bebedouro. Após 5 dias, a dose foi aumentada para $30 \mu \mathrm{moles} / \mathrm{g}$ e o plasma foi obtido para leitura dos níveis do aminoácido. Esse procedimento foi se repetindo a cada 5 dias, para que os animais se acostumassem gradualmente com o sabor do aminoácido, até alcançar a dose máxima de $500 \mu$ moles/g, totalizando 20 dias de tratamento. 


\subsubsection{Determinação dos níveis de prolina no plasma e na urina}

A quantificação de prolina presente no plasma e na urina foi realizada pelo método de Bates et al. (1973) utilizando uma curva-padrão com as seguintes diluições seriadas: 60, 120, 240, 480 e $960 \mu \mathrm{M}$. As amostras foram diluídas com água milli-Q em uma razão de 10 vezes para o plasma e 20 vezes para urina. A reação foi a seguinte: $250 \mu 1$ da amostra foi incubada com $250 \mu \mathrm{l}$ de ácido acético glacial e $250 \mu \mathrm{l}$ de ninidrina $(0,25 \mathrm{~g}$ ninidrina, $6 \mathrm{~mL}$ de ácido acético glacial e $4 \mathrm{~mL}$ de ácido fosfórico $6 \mathrm{M}$ ) por 1 hora a $100{ }^{\circ} \mathrm{C}$. Em seguida, os tubos com as reações foram transferidos para o gelo, onde permaneceram por no mínimo 1 minuto. Para extração da fase orgânica, foi adicionado $500 \mu 1$ de tolueno à reação e então os tubos foram agitados vigorosamente. As fases orgânicas, nas quais participam do complexo formado pela ninidrina e a prolina foram transferidos a uma placa de polipropileno de 96 poços. A leitura das absorbâncias a $515 \mathrm{~nm}$ foi realizada em espectrofotômetro.

\subsection{Obtenção e manutenção das cepas de $T$. cruzi}

\subsubsection{Formas tripomastigotas sanguícolas}

As formas tripomastigotas sanguícolas da cepa $\mathrm{Y}$ de $T$. cruzi foram mantidas por meio de repiques semanais em camundongos da linhagem BALB/c ou C57BL/6. Após uma semana de infecção (por via i.p), os animais foram anestesiados e por meio de punção cardíaca foi realizado sangria na presença de heparina $(14 \mathrm{UI} / \mathrm{mL}$ de sangue) (Sigma), para recuperação das formas tripomastigotas. Esse procedimento (repique in vivo) se repetiu a cada semana a fim de realizar os ensaios de infecção.

\subsubsection{Formas tripomastigotas provenientes de infecções in vitro}

As formas tripomastigotas sanguícolas da cepa Y de T. cruzi foram obtidas de infecções in vivo de camundongos da linhagem $\mathrm{BALB} / \mathrm{c}$ e utilizadas para infecções de células $\mathrm{LLCMK}_{2}$. Os parasitas eclodidos desta garrafa eram utilizados para infecções da mesma linhagem celular mantidas em novas garrafas. A partir daí, a cada semana, os parasitos eclodidos eram utilizados para infecções de novas células para manutenção da forma tripomastigota. As células $\mathrm{LLCMk}_{2}$ eram mantidas a $37^{\circ} \mathrm{C}$ em estufa a $5 \% \mathrm{CO}_{2}$. 


\subsubsection{Formas epimastigotas}

As formas epimastigotas de T. cruzi, cepa CL, clone 14 (Brener, Chiari, 1963) foram mantidas em fase exponencial de crescimento em meio LIT (Liver Infusion-Tryptose) pH 7,2, que contém infusão de fígado 5,0 g/L, Triptose 5,0 g/L, NaCl 4,0 g/L, KCL 0,4 g/L, $\mathrm{Na}_{2} \mathrm{HPO}_{4}$ $8,0 \mathrm{~g} / \mathrm{L}$, glicose $2 \mathrm{~g} / \mathrm{L}$, hemina $10 \mathrm{~g} / \mathrm{L}$ suplementado com $10 \%$ de soro fetal bovino (SFB) a 28 ${ }^{\circ} \mathrm{C}$ (Camargo, 1964). As formas epimastigotas foram mantidas para extração de DNAg e então a construção da curva-padrão para PCR quantitativa.

\subsection{Obtenção e manutenção das cepas de $T$. cruzi transfectadas com TcAAAP069 e GFP.}

\subsubsection{Formas epimastigotas}

As formas epimastigotas de T. cruzi cepa MJL e Y, transfectadas com TcAAAP069 ou GFP foram cedidas por Melisa Sayé e mantidas em fase exponencial de crescimento em meio LIT (Liver Infusion-Tryptose) pH 7,2, que contém infusão de fígado 5,0 g/L, Triptose 5,0 $\mathrm{g} / \mathrm{L}, \mathrm{NaCl}$ 4,0 g/L, KCL 0,4 g/L, $\mathrm{Na}_{2} \mathrm{HPO}_{4} \quad 8,0 \mathrm{~g} / \mathrm{L}$, glicose $2 \mathrm{~g} / \mathrm{L}$, hemina $10 \mathrm{~g} / \mathrm{L}$ suplementado com $10 \%$ de soro fetal bovino (SFB) a $28{ }^{\circ} \mathrm{C}$ (Camargo, 1964), na presença de geniticina. As formas epimastigotas foram mantidas para a indução de metaciclogênese para obtenção de formas tripomastigotas dos quais utilizamos em nossos ensaios.

\subsubsection{Formas tripomastigotas provenientes de infecções in vitro}

As formas epimastigotas da cepa MJL e Y, transfectadas com TcAAAP069 ou GFP (Sayé et al., 2014) foram submetidas à indução de metaciclogênese. Os epimastigotas foram cultivados por 7 a 9 dias a partir de um densidade inicial de $5 \times 10^{7}$ parasitas $/ \mathrm{mL}$, em meio GRACE a $28^{\circ} \mathrm{C}$. O acompanhamento da diferenciação era feito diariamente observando a forma e movimentação dos parasitas presentes no sobrenandante da garrafa, utilizando microscópio invertido. Quando boa parte dos parasitas já estavam diferenciados a tripomastigotas metacíclicos, o sobrenadante da garrafa foi centrifugado a 938 x $g$ por 10 minutos a $4{ }^{\circ} \mathrm{C}$. Os parasitas presentes no sedimento foram utilizados para infecções de células $\mathrm{LLCMk}_{2}$. Os parasitas eclodidos desta garrafa eram utilizados para infecções da mesma linhagem celular mantidas em novas garrafas. A partir daí, a cada semana, os parasitas eclodidos eram utilizados para infecções de novas células para manutenção da forma tripomastigota transfectada. 


\subsubsection{Formas tripomastigotas sanguícolas}

Camundongos da linhagem BALB/c foram infectados com $10^{6}$ formas tripomastigotas provenientes de infecções de cultura celular. Após 7 dias, os animais infectados foram anestesiados e por meio de punção cardíaca foi realizado sangria na presença de heparina (14 $\mathrm{UI} / \mathrm{mL}$ de sangue) (Sigma), para recuperação das formas tripomastigotas sanguícolas. A partir daí, a manutenção in vivo da cepa $\mathrm{Y}$ transfectada de $T$. cruzi foi feita por meio de infecções semanais em camundongos da linhagem BALB/c e recuperação do parasita após sangria total.

\subsection{Infecção e tratamento com prolina}

Camundongos da linhagem BALB/c e C57BL/6 foram infectados com 500 e 1.000 formas de tripomastigotas sanguícolas por via i.p, respectivamente. Após 1 hora, receberam pela mesma via tampão fosfato salino (PBS) - grupo controle - ou prolina diluída em PBS, num volume final de $200 \mu \mathrm{L}$. Os animais foram tratados durante 10 dias. As doses testadas variaram entre a 10 a $2.095 \mathrm{mg} / \mathrm{kg}$ ao dia. O efeito de prolina sobre a infecção de camundongos foi avaliado quanto aos seguintes parâmetros: (a) parasitemia, (b) sobrevida e (c) parasitismo tecidual.

\subsection{Avaliação da parasitemia e sobrevida}

Amostras de sangue foram obtidas da veia caudal dos animais entre o $5^{\circ}$ e $15^{\circ}$ dia após a infecção (d.p.i). Os tripomastigotas móveis foram quantificados em $10 \mu \mathrm{L}$ de sangue, em 25 campos microscópicos (Nikon Eclipse E200) utilizando-se um aumento de 400 x (Brener, 1962). A sobrevida dos animais foi acompanhada durante 40 d.pi.

\subsection{Análise da carga parasitária tecidual}

\subsubsection{Técnica histológica}

O parasitismo tecidual foi avaliado através da contagem aleatória do número de ninhos de amastigotas observados em 20 campos microscópicos, utilizando-se um aumento de $400 \mathrm{x}$ (Castro, Brener, 1985). No $15^{\circ}$ dia após a infecção, amostras de baço, bexiga, coração, intestino, músculo esquelético e pulmão foram coletadas de animais controles e tratados. Os órgãos foram transferidos para o formaldeído $10 \%$ diluído em tampão PBS, e então processados por desidratação gradual em soluções de etanol, seguida de imersão em xileno, e posteriormente emblocados em parafina. Secções de tecido de $5 \mu \mathrm{m}$ de espessura foram obtidas e coradas com hematoxilina e eosina (H\&E) e analisadas por microscopia de luz. 


\subsubsection{Reação em Cadeia da Polimerase quantitativa (PCRq)}

Para confirmar os dados de parasitismo tecidual obtidos por análise histológica, foi adaptada da literatura a técnica PCR em tempo real (Cummings, Tarleton, 2003) e utilizada para quantificar o número de parasitas equivalentes a 5 ng de DNA genômico (DNAg) em 25 mg de tecido. Para isso, foi escolhido o método de "quantificação absoluta baseada na utilização de uma curva-padrão". A vantagem do uso desse método é que não há necessidade que a eficiência de amplificação dos primers para o gene alvo e o gene controle sejam equivalentes. Entretanto, foi necessário utilizar a cada corrida, uma curva-padrão.

No $15^{\circ}$ dia após a infecção, amostras de baço, bexiga, coração, intestino, músculo esquelético e pulmão foram coletadas de animais controles e tratados. As amostras foram congeladas a $-80{ }^{\circ} \mathrm{C}$ para posterior extração de DNAg.

\section{i. Extração de DNAg de tecidos}

A extração de DNAg foi realizada com o "Dnaeasy Blood and Tissue Kit" conforme especificações do fabricante (Quiagen). A concentração de DNAg das amostras foi determinada por espectrofotometria (leitura das absorbâncias a 260 e $280 \mathrm{~nm}$ ) no aparelho NanoDrop (Spectrophotometer ND-1000).

\section{ii. Construção das curvas-padrão}

Para construção da curva-padrão foi extraído DNAg (como descrito acima) de $25 \mathrm{mg}$ de cada tecido previamente contaminado com $5 \times 10^{5}$ epimastigotas da cepa CL-14 de $T$. cruzi. Uma vez ressuspendido no tampão de eluição, o DNAg foi seriadamente diluído a um fator de 1:10.

\section{iii. $\quad$ Montagem da PCR em tempo real (PCRq)}

A PCR $q$ constituiu de $5 \mathrm{ng}$ de DNAg, $0.5 \mu \mathrm{M}$ de primers específicos de $T$. cruzi TCZ direto 5'-GCTCTTGCCCACAMGGGTGC-3', e TCZ reverso 5'CCAAGCAGCGGATAGTTCAGG-3'(Bioneer; Bioneer Corporation; Daedeok-gu, Daejean, Korea do Sul), (onde M corresponde aos nucleotídeos A ou C), $10 \mu \mathrm{L}$ de Sybr Green Master Mix (Fermentas®; Fermentas Canada Inc; Burlington, Ontário, Canadá) e Água Nuclease-free (Fermentas ${ }^{\circledR}$ ), num volume final de $20 \mu \mathrm{L}$. Esses primers amplificam um produto de 182 pares-de-bases. Paralelamente, como controle normalizador para cada amostra, foi feita uma 
reação com primers específicos para fator de necrose tumoral- $\alpha$ (TNF- $\alpha$ ) murino: TNF-5241 direto 5'- TCCCTCTCATCAGTTCTATGGCCCA-3' e TNF-5411 reverso 5'CAGCAAGCATCTATGCACTTAGACCCC-3'(Fermentas) numa concentração de 0,5 $\mu \mathrm{M}$. As placas contendo as reações foram transferidas para o termociclador Eppendorf RealPlex 2/2. A fase de amplificação foi dividida em 3 etapas e submetida a 40 ciclos: $95{ }^{\circ} \mathrm{C}$ por 10 segundos, $63{ }^{\circ} \mathrm{C}$ por 15 segundos e $72{ }^{\circ} \mathrm{C}$ por 8 segundos. A última fase foi a construção da curva de desnaturação $\left(95^{\circ} \mathrm{C}\right.$ por 1 segundo, $60{ }^{\circ} \mathrm{C}$ por 30 segundos e $90{ }^{\circ} \mathrm{C}$ por 1 segundo).

\section{iv. Tratamento de dados}

Os valores de Ct (Cycle threshold) obtidos pelo software Eppendorf RealPlex 2/2 versão 1.5 foram transformados em números de parasitas equivalentes $\left(\mathrm{P}_{\mathrm{E}}\right)$ a $5 \mathrm{ng}$ de DNA tecidual e suas médias foram corrigidas de acordo com os produtos de TNF- $\alpha$ (Cummings e Tarleton, 2003), como descrito a seguir: Os números de $\mathrm{P}_{\mathrm{E}}$ a $5 \mathrm{ng}$ de DNA tecidual foram obtidos em escala logarítmica (utilizando primers TCZ ou TNF- $\alpha$ ) por meio da fórmula $y=$ $m x+b$, onde: $m=$ inclinação da curva; $b=Y$ na origem; $x=$ variável $(C t)$. Os valores obtidos em escala logarítmica (tanto para os produtos de TCZ quanto para TNF- $\alpha$ ) foram transformados a números de parasitas, elevando cada valor obtido à base 10. Uma vez obtidos os números reais de $\mathrm{P}_{\mathrm{E}}$ a $5 \mathrm{ng}$ de DNA tecidual para ambos pares de primers, foram feitas as normalizações. Todos os valores (números reais de $\mathrm{P}_{\mathrm{E}}$ a $5 \mathrm{ng}$ de DNA tecidual) obtidos para o produto de TNF- $\alpha$ foram divididos pelo maior valor do produto desse mesmo par de primer. A razão obtida aqui para cada amostra, foi multiplicada respectivamente por cada valor do produto de TCZ. E a partir dos valores obtidos aqui, as médias e o erro padrão foram determinados para cada grupo experimental.

\subsection{Obtenção de células peritoniais}

As células peritoneais foram obtidas de camundongos da linhagem BALB/c de acordo com o protocolo descrito por Camargo et al. (1997). O lavado peritonial foi coletado e diluído em meio de cultura DMEM não suplementado. Após centrifugação a 269 x $g, 4{ }^{\circ} \mathrm{C}$ por 10 minutos, as células foram ressuspendidas em meio DMEM não suplementado e quantificadas em câmara de Neubauer, na presença de azul de tripan 0,2\%, para a determinação da viabilidade e densidade celular. 


\subsection{Cultivo de células peritoneais para dosagem de óxido nítrico}

As células foram cultivadas em placas de 96 poços numa densidade de 1 x $10^{6}$ células viáveis/poço na presença de DMEM não suplementado. Após a incubação por 2 horas a 37 ${ }^{\circ} \mathrm{C}$, em $5 \%$ de $\mathrm{CO}_{2}$, os poços contendo as células foram lavados com PBS para retirada de células não-aderentes. As células aderidas foram submetidas à infecção over-night, com parasitas provenientes de infecções in vitro, na mesma estufa, em proporção de 5:1 tripomastigotas por célula, na presença de $200 \mu \mathrm{L}$ de meio DMEM completo (SFB 10\%). No dia seguinte, os poços foram lavados com PBS para retirada dos parasitas que não invadiram as células. Às células aderidas foi adicionado $100 \mu \mathrm{L}$ de meio DMEM completo ou $3 \mathrm{mM}$ de prolina. Também foi adicionado $1 \mu \mathrm{g}$ de lipopolissacarídeo (LPS) de Escherichia coli e a placa mantida por 48 horas nas condições de incubação descrita acima. Passado o tempo de incubação os sobrenadantes foram obtidos para a dosagem de óxido nítrico (NO).

\subsubsection{Dosagem de óxido nítrico}

A produção de NO foi avaliada indiretamente pela dosagem de nitrito, um dos produtos estáveis da síntese de NO-nitrito $\left(\mathrm{NO}_{2}{ }^{-}\right)$, utilizando-se a reação de Griess $(1 \%$ de sulfanilamida, 0,1\% de $\alpha$-naftil e 2,5\% de ácido fósforico em água destilada deionizada) (Ding et al., 1988). As dosagens foram feitas em placas de 96 poços com $50 \mu$ do sobrenadante da cultura de células e $50 \mu \mathrm{L}$ do regente Griess em cada poço. Paralelamente foi utilizada uma curva padrão do qual consistiu de diluições seriadas de nitrito. A esses poços contendo diluições seriadas de nitrito também foi adicionado reagente de Griess. A placa permaneceu em local escuro por 20 minutos e em seguida foi feita a leitura em comprimento de onda de $515 \mathrm{~nm}$ no espectrofotômetro. Uma vez obtidos os valores de absorbância das amostras e o valor de inclinação da curva-padrão foram calculadas as concentrações de nitrito nos sobrenadantes das culturas.

\subsection{Cultivo de células peritoneais para teste de toxicidade}

As células provenientes do lavado peritoneal foram cultivadas em placas de 24 poços numa densidade de $5 \times 10^{5}$ células por poço. Após a incubação por 2 horas em estufa de $5 \%$ $\mathrm{CO}_{2}$ umidificada, a $37^{\circ} \mathrm{C}$, os poços contendo as células foram lavados com PBS para retirada de células não-aderentes. As células não aderidas foram cultivadas em meio DMEM suplementado com SFB (10\%) na presença de diferentes concentrações de prolina. As placas 
foram mantidas nas mesmas condições de incubação por 48 horas. Após esse período a viabilidade celular foi avaliada utilizando-se o reagente MTT (3-(4,5-dimetiltiazol-2-yl)-2,5diphenil tretazolium bromide) (Mosmann, 1983). Para isso, as células foram lavadas duas vezes com PBS, em cada poço foi adicionado $300 \mu \mathrm{L}$ de PBS e $60 \mu \mathrm{L}$ MTT ( $5 \mathrm{mg} / \mathrm{mL})$. Em seguida, as placas foram incubadas na mesma estufa durante 3 horas (protegidas da luz). A reação foi interrompida com a adição de $200 \mu \mathrm{L}$ de SDS 10\%. A viabilidade das células foi observada mediante o aparecimento da cor azul de formazan homogêneo. A leitura das placas foram realizadas em espectofotômetro utilizando-se $\chi 595 \mathrm{~nm}$ e como referência $\chi 690 \mathrm{~nm}$.

\subsection{Cultivo de células peritoneais para avaliação da expressão gênica de mediadores pró- e anti-inflamatórios, utilizando PCRq}

As células foram cultivadas em placas de 6 poços na concentração de 2 × $10^{6}$ células viáveis/poço. Após a incubação por 2 horas em estufa de $5 \% \mathrm{CO}_{2}$ umidificada, a $37{ }^{\circ} \mathrm{C}$, os poços contendo as células foram lavados com PBS para retirada de células não-aderentes, 2 $\mathrm{mL}$ de meio DMEM completo (SFB 10\%) foi adicionado e as células mantidas nas mesmas condições de incubação até o dia seguinte. As células foram lavadas mais uma vez com PBS e então incubadas com DMEM completo ou na presença de diferentes concentrações de prolina. Também foi adicionado $100 \mathrm{ng} /$ poço de LPS de E. coli. As placas foram incubadas na mesma estufa por 18 horas.

\subsubsection{Extração de RNA de células peritoneais}

Após o período de 18 horas de incubação, os sobrenadantes das culturas de células foram descartados e as células aderidas foram homogeneizadas com $1 \mathrm{~mL}$ de Trizol. Após 5 minutos de incubação em temperatura ambiente, os homogeneizados foram transferidos para tubos de 1,5 mL, onde foi adicionado $0,2 \mathrm{~mL}$ de clorofórmio e incubados por mais 3 minutos. Os tubos contendo as amostras foram centrifugados a $12.000 \mathrm{x} g$ a $4{ }^{\circ} \mathrm{C}$ por 15 minutos. A fase aquosa foi recuperada e adicionou-se a ela $0,5 \mathrm{~mL}$ de isopropanol. As amostras foram incubadas por 10 minutos e em seguida centrifugadas a 12.000 x $g$ à $4{ }^{\circ} \mathrm{C}$ por 10 minutos. Posteriormente, o sobrenadante foi desprezado e a esse sedimento foi adicionado $1 \mathrm{~mL}$ de etanol $75 \%$. Os tubos novamente foram centrifugados, desta vez a 7.500 x $g$ por 5 minutos a 4 ${ }^{\circ} \mathrm{C}$. Finalmente, os sedimentos contendo o RNA purificado foi eluído em $10 \mu \mathrm{L}$ de água livre de ribonucleases (DEPC). As amostras de RNA foram tratadas com DNAse, com a finalidade 
de eliminar possíveis contaminações das amostras com DNA genômico. A concentração de RNA das amostras foi determinada por espectrofotometria em aparelho NanoDrop.

\subsubsection{Síntese de cDNA a partir de RNA de células peritoneais}

Após a extração de RNA foram realizadas as sínteses de cDNAs, utilizando todo o conteúdo de RNA extraído de células peritoneais. A reação foi realizada utilizando $200 \mathrm{U}$ de transcriptase reversa SuperscriptII (Invitrogen; Life Technologies Corporation; CA, Estados Unidos), 50 ng de oligonucleotídeos (hexâmeros aleatórios) ou 250 ng de oligo-dT, 2,5 mM de dNTPs, $10 \mathrm{mM}$ de DTT, $40 \mathrm{U}$ de RNase $O U T$ e tampão $1 \mathrm{X}$ da transcriptase reversa, segundo instruções do fabricante (Invitrogen). Os cDNAs obtidos foram diluídos 5 vezes com água milli- $Q$ e armazenados a $-20^{\circ} \mathrm{C}$ até o momento em que fosse feita a PCRq.

\subsubsection{Teste de eficiência dos primers iNOS, IL-10, TGF- $\beta$, TNF- $\alpha$ e ACT- $\beta$ (actina- $\beta$ ).}

Antes de avaliar a expressão gênica por PCRq em células peritoneais, foi necessário certificar-se que os quatro pares de primers escolhidos para iNOS, IL-10, TGF- $\beta$ e TNF- $\alpha$, amplificassem as amostras de cDNA com a mesma eficiência que ACT- $\beta$. O valor de inclinação da curva que é fornecido com a construção da curva-padrão não necessita exatamente ser $-3,3+0,1$. O valor de inclinação da curva gerada pelo par de primers teste deve corresponder ao valor de inclinação da curva do par de primers normalizadores (gene referência endógeno) para a mesma amostra de cDNA, com desvio padrão $\pm 0,1$. Para isso, amostras de cDNA de células peritoneais que receberam estímulo por LPS foram diluídas seriadamente para construção da curva de regressão linear por meio de PCRq, utilizando os quatro pares de primers.

\subsubsection{PCRq via transcriptase reversa $(P C R-R T)$}

As amostras de cDNA de células peritoneais foram submetidas à reação de PCRq utilizando $5 \mu \mathrm{L}$ dos seguintes primers: iNOS (concentração do estoque: $2 \mu \mathrm{M}$ ), direto 5 'CACCTTGGAGTTCACCCAGT-3' e reverso 5'-ACCACTCGTACTTGGGATGC -3'; IL10 (concentração do estoque: 1,6 $\mu \mathrm{M}$ ), direto 5'-GGTTGCCAAGCCTTATCGGA-3' e reverso 5'-ACCTGCTCCACTGCCTTGCT-3'; TNF- $\alpha$ (concentração do estoque: 1,6 $\mu \mathrm{M}$ ), direto 5'- CATCTTCTCAAAATTCGAGTGACAA -3' e reverso 5'TGGGAGTAGACAAGGTACAACCC'; TGF- $\beta$ (concentração do estoque: 1,6 $\mu \mathrm{M}$ ), direto 5'- TGACGTCACTGGAGTTGTACGG - $3^{\prime}$ e reverso 5'- 
GGTTCATGTCATGGATGGTGC'; e como normalizadores, primers para ACT- $\beta$ (concentração do estoque: 1,6 $\mu \mathrm{M}$ ), direto 5-AGCTGCGTTTTACACCCTTT-3' e reverso 5'-AAGCCATGCCAATGTTGTCT-3', $5 \mu \mathrm{L}$ de cada amostra de cDNA como molde e $5 \mu \mathrm{L}$ de SYBR Green (Fermentas) sob as seguintes condições: $94{ }^{\circ} \mathrm{C}$ por 5 minutos, 40 ciclos de 94 ${ }^{\circ} \mathrm{C}$ por 15 segundos e $60{ }^{\circ} \mathrm{C}$ por 30 segundos, $72{ }^{\circ} \mathrm{C}$ por 15 segundos. A curva de dissociação foi realizada como segue: $95^{\circ} \mathrm{C}$ por 1 segundo; $60{ }^{\circ} \mathrm{C}$ por 30 segundos e $90{ }^{\circ} \mathrm{C}$ por 1 segundo.

\subsubsection{Tratamento dos dados de PCRq-RT}

Os dados foram obtidos pelo software Eppendorf RealPlex 2/2 versão 1.5 e analisado pelo método de $\Delta \Delta \mathrm{Ct}$ comparativo no qual obtêm-se a razão entre a expressão do gene alvo de células tratadas e as não tratadas. Primeiramente, foi obtida a razão relativa da abundância de transcritos dos quatro genes (iNOS, IL-10, TGF- $\beta$ e TNF- $\alpha$ ) em relação ao normalizador (ACT- $\beta$ ), que foi calculada através da diferença entre as médias dos Ct's do gene alvo e a média dos Ct's do gene normalizador, de acordo com a seguinte fórmula:

$$
\Delta C t=C t \text { gene alvo - } C t \text { gene normalizador. }
$$

Em seguida foi obtida a razão entre a expressão do gene alvo de células tratados e as não tratadas, através da seguinte fórmula:

$$
\Delta \Delta C t=\Delta C t \text { células tratadas }-\Delta C t \text { células não tratadas }
$$

Já que o valor de Ct é proporcional ao logaritmo da quantidade do gene alvo presente nas amostras (Pfaffl, 2001), o valor final foi dado através seguinte fórmula aritmética:

$$
2^{-\Delta \Delta C t}
$$

\subsection{Cultivo de células peritoneais para ensaio de infecção}

As células provenientes do lavado peritoneal foram cultivadas (numa densidade de $5 \mathrm{x}$ $10^{5}$ células por poço) em placas de 24 poços contendo lamínulas de vidro. Após a incubação de 2 horas em estufa de $5 \% \mathrm{CO}_{2}$ umidificada, a $37{ }^{\circ} \mathrm{C}$, os poços com lamínulas contendo as 
células foram lavados com PBS para retirada de células não-aderentes. As células aderidas nas lamínulas foram incubadas com DMEM suplementado (10\% SFB) ou com diferentes concentrações de prolina $(300 \mu \mathrm{M}$ a $3 \mathrm{mM})$. Em seguida, tripomastigotas provenientes de cultivo tecidual $\left(\mathrm{LLCMK}_{2}\right)$, foram adicionados à cultura, numa proporção de 5:1 por célula. A placa foi mantida overnigh na mesma estufa. No dia seguinte, os poços foram lavados com PBS para retirada dos parasitas que não invadiram as células. Às células aderidas foram adicionados $500 \mu \mathrm{L}$ de meio DMEM completo ou diferentes concentrações de prolina (300 $\mu \mathrm{M}$ a $3 \mathrm{mM}$ ). A placa foi devolvida à estufa e mantida por 48 ou 72 horas. Após esse período as lamínulas contendo células aderidas foram retiradas da placa e coradas com panótipo, de acordo com instruções do fabricante (Laborclin), para visualização no microscópio de luz.

\subsection{Determinação da área citoplasmática de células peritoneais}

Após o período de 48 horas de incubação com diferentes concentrações de prolina, as células peritoneais aderidas às lamínulas, infectadas ou não, foram coradas por panótipo de acordo com instruções do fabricante (Laborclin). As lamínulas foram fotografadas no aumento de 400 ou 1.000 x em microscópio de luz e as imagens foram processadas por meio do software computacional Image $J$, do qual nos possibilitou quantificar a área, em micrômetros quadrados.

\subsection{Avaliação da prolinemia em pacientes chagásicos}

Os níveis séricos foram avaliados em amostras de soro provenientes de três grupos de pacientes chagásicos do Hospital Centenario de Rosario/Santa Fé - Argentina e de um grupo controle (indivíduos não infectados). As amostras foram cedidas pelos professores Dr. Oscar Bottasso, Dra Ana Rosa Pérez e Dr. Juan Beloscar da Facultad de Ciências Médicas de Rosario. Os três grupos de pacientes chagásicos eram diferentes quanto a sua sintomatologia, sendo que o primeiro grupo foi composto por pacientes de fase indeterminada, o segundo por pacientes com cardiopatia leve e moderada e o terceiro por pacientes com cardiopatia severa. A avaliação da prolinemia foi realizada como descrito no ítem 3.2.2.

\subsection{Obtenção de camundongos PRO/ReJ e expansão da colônia}

Foram adquiridos dois casais de camundongos PRO/ReJ com fundo C57BL/6 da companhia The Jackson Laboratory, com o objetivo de iniciar o processo de expansão da colônia. Devido à morosidade do processo de entrega dos animais no Brasil, os animais 
chegaram com idade avançada e apenas um macho estava viável para acasalamento. Iniciamos então o processo de recuperação da linhagem, acasalando o único macho PRO/ReJ com fêmeas selvagens C57BL/6 oriundas de nosso biotério. As fêmeas descendentes provenientes da geração F1 foram acasaladas com o macho parental PRO/ReJ. Camundongos homozigóticos recessivos da geração F2 foram cruzados entre si, ou novamente com o macho parental. A geração F3 constituída por 100\% de homozigóticos foi acasalada entre si ou com o macho parental a fim de expandir a quantidade de casais fundadores.

\subsubsection{Seleção camundongos PRO/ReJ por genotipagem}

Amostras de cauda dos camundongos provenientes da geração F2 e F3 foram obtidas para realizar o processo de genotipagem.

(i) Extração de DNAg de amostras de caudas

A extração de DNAg foi realizada com o "Dnaeasy Blood and Tissue Kit” conforme especificações do fabricante (Quiagen). A concentração de DNAg das amostras foi determinada por espectrofotometria (leitura das absorbâncias a 260 e $280 \mathrm{~nm}$ ) no aparelho NanoDrop (Spectrophotometer ND -1000).

(ii) Montagem da reação em cadeia da polimerase (PCR)

A PCR constituiu de $100 \mathrm{ng}$ de DNAg, $50 \mu \mathrm{M}$ de iniciadores específicos para PRODH direto 5'- GACCAAATCAGCTTCCCACT - $3^{\prime}$ e reverso 5'CCCTTCATGATGCTGCTGTT - 3', KCl (50 mM), Tris-HCl (10 mM, pH 8.3), MgCl2 (1.5 $\mathrm{mM})$, dNTPs $(200 \mu \mathrm{M}$ de cada) e Taq polymerase $(1.5 \mathrm{U})$. A PCR foi realizada com o seguinte programa: um ciclo de $80{ }^{\circ} \mathrm{C}$ por 8 minutos, 30 ciclos de $92^{\circ} \mathrm{C}$ por 1 minuto, $60{ }^{\circ} \mathrm{C}$ por 40 segundos e $72{ }^{\circ} \mathrm{C}$ por 1 minuto. A corrida foi finalizada por um ciclo de $72{ }^{\circ} \mathrm{C}$ durante 7 minutos (Gogos et al., 1999).

\section{(iii) Purificação do produto de PCR}

A purificação do produto de PCR foi realizada a fim de remover primers, dNTPs, sais e enzima dos quais poderiam interferir com a atividade da enzima de restrição no passo seguinte. O processo de purificação foi realizado utilizando o PureLink PCR Purification Kit conforme especificações do fabricante Invitrogen. 
(iv) Corte do fragmento com Enzima de restrição MnlI.

Após purificação do produto de PCR, todo o volume $(45 \mu \mathrm{L})$ foi utilizado para a reação de corte com a enzima de restrição $M n l I$. Foi adicionado então, $5 \mu \mathrm{L}$ de Buffer G e 1 $\mu \mathrm{L}$ da enzima. A reação foi incubada à $37^{\circ} \mathrm{C}$ por 2 horas. Após esse período, as reações foram incubadas na temperatura de $65^{\circ} \mathrm{C}$ por 20 minutos, para inativação da enzima.

(v) Eletroforese em Gel de Agarose

A técnica de eletroforese foi utilizada para visualizar os diferentes padrões de bandas que são dados após corte com a enzima de restrição MnlI e então ser possível realizar a genotipagem. Foi adicionado tampão de amostra de DNA em todo volume obtido após o corte com a enzima de restrição e então feita a corrida no Gel 4\% Agarose. Após a corrida, o gel foi fotografado em câmara escura sob exposição de luz ultravioleta.

\subsection{Ensaio de infecção em camundongos PRO/ReJ}

Para validação do modelo hiperprolinêmico foi avaliado sua prolinemia conforme descrito no item 3.2.2. Os animais foram infectados com 1.000 formas de tripomastigotas sanguícolas por via i.p. O grupo controle foi constituído por camundongos da linhagem C57BL/6. A parasitemia foi acompanhada entre o $5^{\circ}$ e o $18^{\circ}$ d.p.i e a mortalidade até o $40^{\circ}$ d.p.i, conforme descrito no item 3.6.

\subsection{Análises de dados e estatísticas}

Os dados foram inseridos no programa computacional GraphPad Prism versão 4.0, GraphPad Software para construção dos gráficos. Os testes estatísticos utilizados foram t-test, One-Way ANOVA, Tukey post-test e Logrank-test. As diferenças estatísticas cujos os valores de $\mathrm{p}<0,05$ foram considerados significantes. 


\section{RESULTADOS}

\subsection{Construção de um modelo de hiperprolinemia}

Para estudar a prolinemia como fator de severidade na infecção pelo T. cruzi, o primeiro passo foi estabelecer um modelo experimental no qual os níveis sanguíneos de prolina fossem artificialmente aumentados. Como estratégia para este projeto, estabelecemos como método inicial, injeções diárias por via intraperitoneal (i.p) de diferentes concentrações do aminoácido em camundongos. Camundongos da linhagem BALB/c que receberam injeções a partir de 10 $\mu$ moles/g já apresentaram níveis plasmáticos de prolina acima do normal, atingindo um pico prolinêmico em 30 minutos e voltando a níveis normais em 2 horas. Após 30 minutos da injeção, os camundongos controle apresentaram uma concentração de 0,519 $\pm 0,032 \mathrm{mM}$ de prolina no plasma. As concentrações plasmáticas nos animais que receberam $0,8 \mu$ moles/g foi de 0,543 $\pm 0,046 \mathrm{mM}$ e nos animais tratados com $10 \mu$ moles/g foi de 1,359 $\pm 0,121 \mathrm{mM}$. Já em animais que receberam 18,2 $\mu$ moles/g, os níveis plasmáticos de prolina foram cinco vezes maiores que os valores obtidos no grupo controle. Nesse grupo a concentração plasmática foi de 2,654 $\pm 0,304 \mathrm{mM}$ (Figura $5 \mathrm{~A}$ ).

A partir destes primeiros dados nos interessou pesquisar se o mesmo padrão cinético com relação a prolinemia induzida artificialmente, observado para camundongos da linhagem BALB/c, ocorre em camundongos C57BL/6. Observou-se que o pico da concentração de prolina também ocorreu 30 minutos após a injeção de prolina, e que camundongos da linhagem C57BL/6 que receberam $18 \mu$ moles/g tiveram seus níveis plasmáticos com valores muito próximos aos de camundongos BALB/c. Em 30 minutos o valor alcançado foi de 2,485 $\pm 0,6608 \mathrm{mM}$ (Figura $5 \mathrm{~B}$ ). Da mesma maneira, o nível máximo de prolina na urina de camundongos BALB/c ocorreu 30 minutos após a injeção de $18 \mu \mathrm{moles} / \mathrm{g}$, chegando a uma concentração de prolina de 356,5 \pm 49,41 mM. Para animais que receberam 10 ou 14 $\mu$ moles/g, os níveis do aminoácido na urina foram de 12,70 \pm 4,555 e 49,73 $\pm 11,98$ mM, respectivamente. No entanto, essas diferenças observadas nestes dois grupos não foram estatisticamente significativas em relação ao controle que apresentou concentração de 1,141 \pm $0.1044 \mathrm{mM}$ (Figura 5 C). 


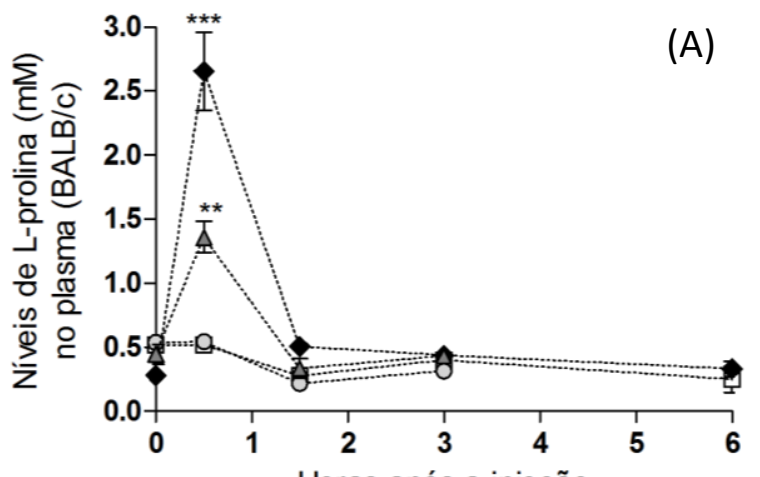

Horas após a injeção

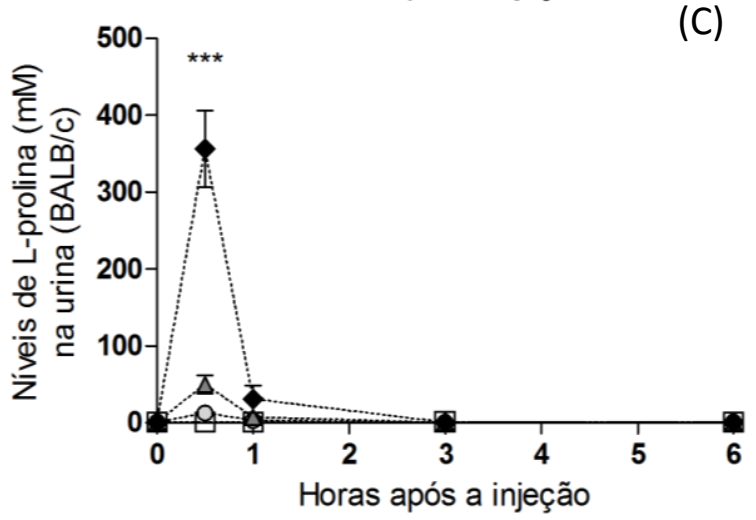

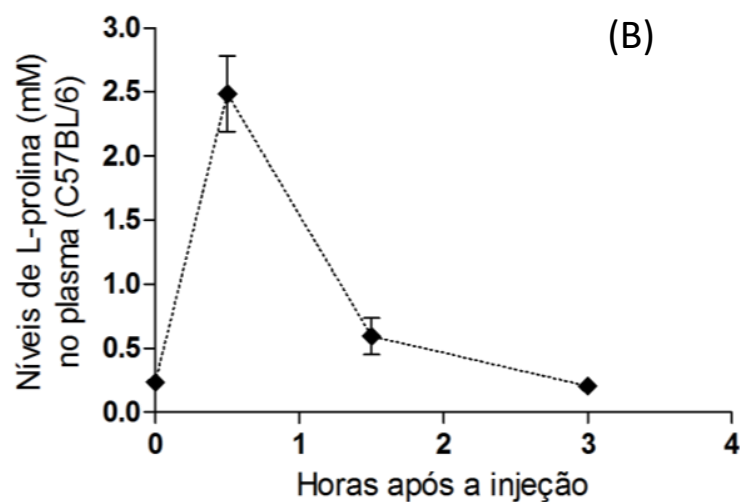

-曰. Controle

.o. 0,8 $\mu$ moles/g

$\therefore \triangle 10 \mu$ moles/g

- 18,2 4 moles/g

Figura 5 - Evolução dos níveis de prolina no plasma e na urina em camundongos. Camundongos da linhagem BALB/c e C57BL/6 receberam diferentes doses de prolina por via i.p. Os níveis de prolina no plasma e na urina foram acompanhados nos seguintes tempos: 0,5 - 1,5-3-6 horas após a injeção. A concentração de prolina foi determinada utilizando um método modificado a partir de Bates et al. (1973). Médias e erros-padrão dos grupos: (A) BALB/c, controle, $\mathrm{n}=5$ (tratados apenas com o veículo PBS); 0,8 $\mu$ moles/g, $\mathrm{n}=5 ; 10 \mu$ moles/g, $\mathrm{n}=3 ; 18,2 \mu$ moles $/ \mathrm{g}, \mathrm{n}=5$. (B) C57BL/6, 18,2 $\mu$ moles/g, $\mathrm{n}=5$. Em (C), níveis de prolina na urina de camundongos BALB/c, controle, $\mathrm{n}=5 ; 10 \mu$ moles/g, $\mathrm{n}=5 ; 14 \mu$ moles/g, $\mathrm{n}=4 ; 18,2 \mu$ moles/g, $\mathrm{n}=4$.

O modelo de hiperprolinemia desenvolvido através do regime de administração descrito acima produziu uma hiperprolinemia transiente, sendo que o aumento dos níveis de prolina não se manteve de maneira estável ao longo do tempo. O aminoácido foi totalmente eliminado, através da urina, em 2 horas após a injeção.

Dado que a indução de hiperprolinemia por injeção i.p do aminoácido foi transitória, resolveu-se explorar uma estratégia alternativa: a administração da prolina por via oral. A prolina foi administrada junto com a água, do qual foi oferecida num regime ad libitum por 20 dias. Durante e após esse período não vimos nenhuma diferença significativa nos níveis de prolina plasmática entre os grupos tratados $(18,2 ; 30 ; 100$ e $500 \mu$ moles/g) e o grupo controle (Figura 6). Além disso, percebemos que o tratamento com a maior dose (500 $\mu$ moles/g) 
deixou os animais com pêlos arrepiados, o que seria um indício de efeito tóxico, no entanto, a sobrevida não foi afetada.

(A)
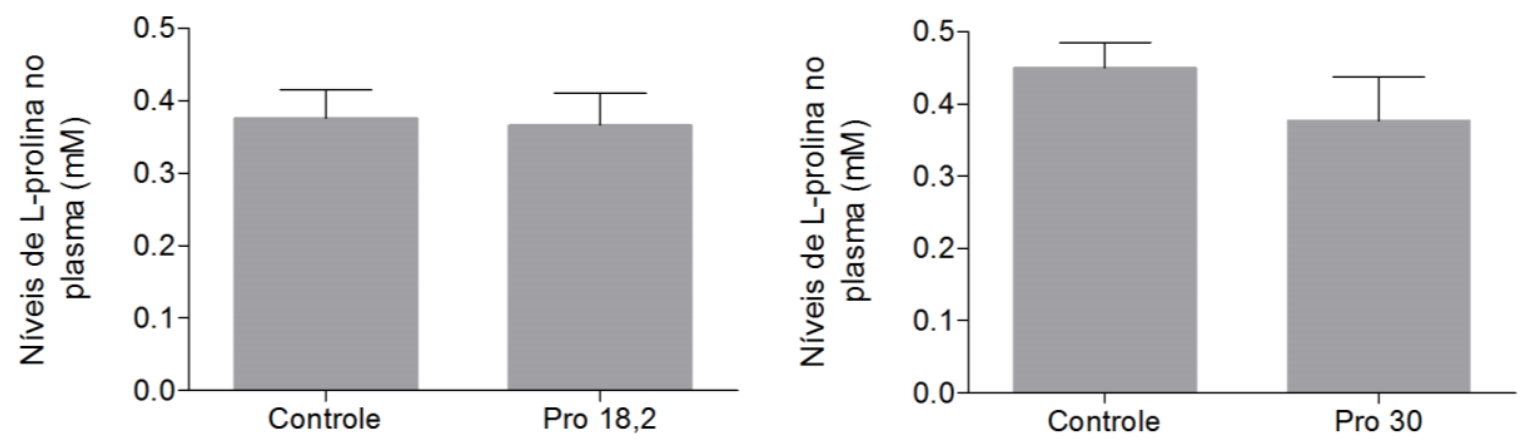

(C)

(D)
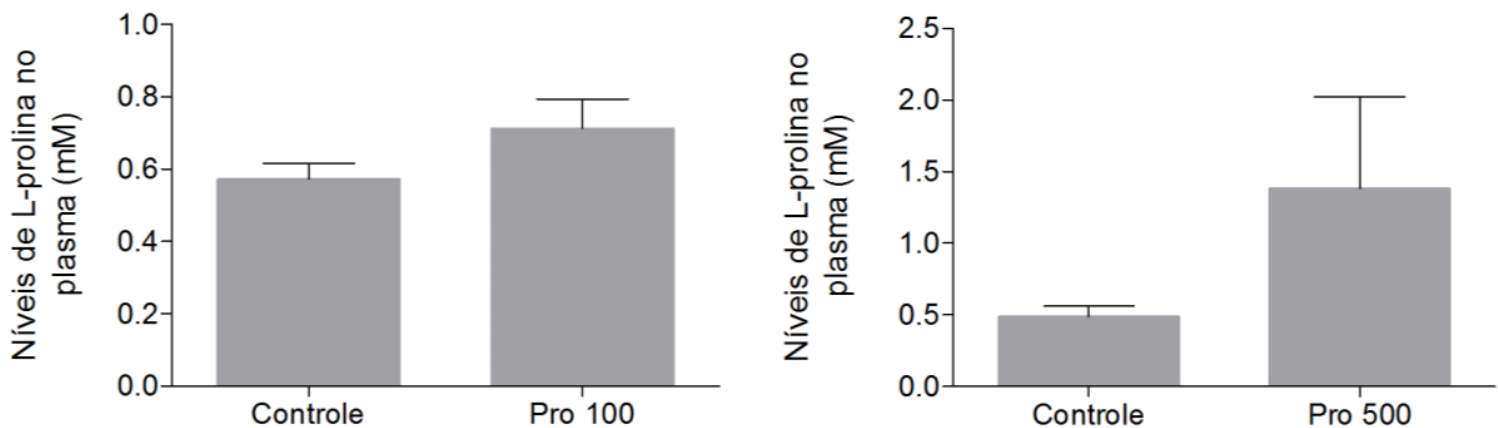

Figura 6 - Monitoramento dos níveis de prolina plasmática após sua administração oral. Camundongos da linhagem BALB/c receberam concentrações crescentes de prolina pelo bebedouro com regime ad libidum, durante 20 dias. Nesse período a prolina foi aumentada gradualmente a cada 5 dias. As concentrações utilizadas foram de 18,2; 30; 100 e $500 \mu$ moles/g de peso corporal. A concentração média de prolina (com seus errospadrã) foi determinada utilizando um método modificado a partir de Bates et al 1973. Grupos controle receberam apenas água $(\mathrm{n}=5)$ e tratados receberam prolina diluída em água $(\mathrm{n}=5)$.

Como parâmetro de toxicidade nós acompanhamos o ganho de peso em camundongos da linhagem BALB/c que receberam $18 \mu$ moles/g durante e após o tratamento com prolina por via i.p. Evidenciou-se que, este tratamento não interferiu com o ganho de peso dos animais, e portanto não resultou tóxico (Figura 7). 


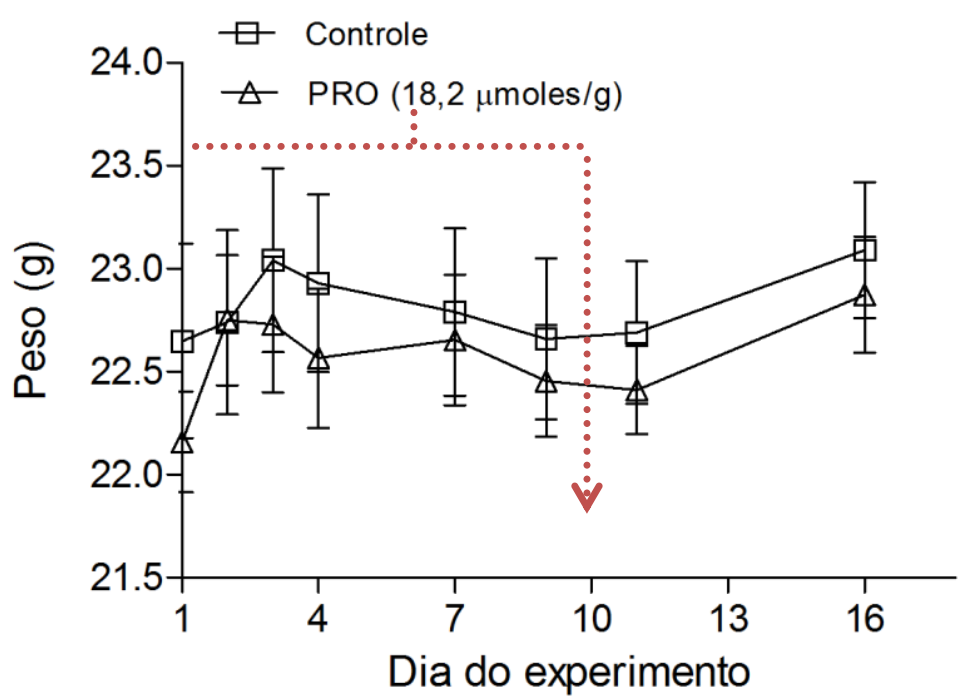

Figura 7 - Evolução do peso corporal durante e após o tratamento com prolina por via i.p. Camundongos da linhagem BALB/c receberam $18 \mu$ moles/g de prolina por via i.p durante 10 dias. O peso corporal foi monitorado durante o tratamento e até seis dias após.

\subsection{Efeito da hiperprolinemia transiente sobre a severidade da infeção em camundongos}

Das estratégias utilizadas, a única que produziu um aumento efetivo na prolinemia foram as injeções de prolina por via ip. Embora, como já mencionado, esse aumento da prolinemia foi transiente, consideramos a possibilidade de avaliar o efeito desse perfil sobre a parasitemia e sobrevida de camundongos infectados pelo T. cruzi. Foram realizados seis ensaios de infecção e tratamento com prolina. Os resultados obtidos foram extremamente dispersos (Tabela 1) sendo que em apenas três experimentos, observou-se um aumento na parasitemia em animais tratados (Figuras 8 B, D, E), sendo que em um deles, a diferença ocorreu no grupo tratado com $18 \mu$ moles/g (Figura 8 D) e nos outros dois, ocorreu no grupo tratado com 14 $\mu$ moles/g (Figuras 8 B, E). Nos três experimentos, a diferença ocorreu apenas no $8^{\circ}$ dia após a infecção. 
Tabela 1 - Picos parasitêmicos de animais infectados e tratados com prolina. Números de parasitas/mL nos dias 8 e 9 após a infecção (d.p.i) de camundongos tratados i.p ou não com prolina (PRO) com doses de 14 a $30 \mu \mathrm{mloes} / \mathrm{g}$. Os valores estão expressos em médias e erros-padrão. Testes estatísticos utilizados: teste $t$; one-way ANOVA e Tukey post-test.

\begin{tabular}{|c|c|c|c|c|c|c|c|c|}
\hline & D.p.i & Controle & $P R O 14 \mu$ moles $/ \mathrm{g}$ & PRO 18,2 $\mu$ moles $/ \mathrm{g}$ & $P R O 30 \mu$ moles $/ \mathrm{g}$ & Estatística & $\begin{array}{c}\text { Valor } \\
\text { dep }\end{array}$ & Pós-teste estatístico \\
\hline \multicolumn{9}{|l|}{ Ensaio 1} \\
\hline & 8 & $12,21 \pm 4,610 \mathrm{~N}=5$ & $16,60 \pm 2,568 \mathrm{~N}=5$ & ---- & ---- & teste $\mathrm{t}$ & 0,429 & não aplicável \\
\hline & 9 & $34,00 \pm 3,276 \mathrm{~N}=5$ & $37,08 \pm 5,749 \mathrm{~N}=5$ & ---- & ---- & & 0,6549 & não aplicável \\
\hline \multicolumn{9}{|l|}{ Ensaio 2} \\
\hline & 8 & $20,57 \pm 4,160 \mathrm{~N}=6$ & $41,38 \pm 4,841 \mathrm{~N}=6$ & ---- & $-\cdots--$ & teste $\mathrm{t}$ & 0,0086 & não aplicável \\
\hline & 9 & $42,57 \pm 6,424 \mathrm{~N}=6$ & $40,12 \pm 5,758 \mathrm{~N}=6$ & ---- & ---- & & 0,7823 & não aplicável \\
\hline \multicolumn{9}{|l|}{ Ensaio 3} \\
\hline & 8 & $40,29 \pm 4,849 \mathrm{~N}=6$ & $54,28 \pm 7,586 \mathrm{~N}=6$ & ---- & ----- & teste $\mathrm{t}$ & 0,1513 & não aplicável \\
\hline & 9 & $52,20 \pm 7,174 \mathrm{~N}=6$ & $62,43 \pm 4,933 \mathrm{~N}=6$ & ---- & ---- & & 0,2672 & não aplicável \\
\hline \multicolumn{9}{|l|}{ Ensaio 4} \\
\hline & 8 & $44,85 \pm 6,783 \mathrm{~N}=5$ & $68,27 \pm 6,274 \mathrm{~N}=6$ & $77,70 \pm 8,982 \mathrm{~N}=6$ & ----- & one-way ANOVA & 0,0268 & diferença entre controle e PRO 18,2 $\mu$ moles/g \\
\hline & 9 & $41,77 \pm 9,195 \mathrm{~N}=5$ & $37,35 \pm 6,264 \mathrm{~N}=6$ & $33,61 \pm 6,630 \mathrm{~N}=6$ & ----- & & 0,743 & sem diferença \\
\hline \multicolumn{9}{|l|}{ Ensaio 5} \\
\hline & 8 & $5,033 \pm 1,017 \mathrm{~N}=10$ & $14,75 \pm 2,329 \mathrm{~N}=9$ & $6,446 \pm 1,041 \mathrm{~N}=10$ & ---- & one-way ANOVA & 0,0003 & diferença entre controle e PRO $14 \mu$ moles $/ \mathrm{g}$ \\
\hline & 9 & $20,43 \pm 4,756 \mathrm{~N}=10$ & $33,85 \pm 4,507 \mathrm{~N}=9$ & $30,20 \pm 4,156 \mathrm{~N}=11$ & ---- & & 0,116 & sem diferença \\
\hline \multicolumn{9}{|l|}{ Ensaio 6} \\
\hline & 8 & $37,85 \pm 8,060 \mathrm{~N}=6$ & $44,30 \pm 7,752 \mathrm{~N}=7$ & $51,22 \pm 12,75 \mathrm{~N}=5$ & $57,42 \pm 7,443 \mathrm{~N}=8$ & one-way ANOVA & 0,4115 & sem diferença \\
\hline & 9 & $31,66 \pm 4,397 \mathrm{~N}=6$ & $44,46 \pm 5,201 \mathrm{~N}=8$ & $32,21 \pm 3,202 \mathrm{~N}=5$ & $44,32 \pm 3,997 \mathrm{~N}=10$ & & 0,0946 & sem diferença \\
\hline
\end{tabular}




\section{Controle \\ Pro (14 $\mu$ moles/g) \\ Pro $(18,2 \mu \mathrm{moles} / \mathrm{g})$ \\ Pro $(30 \mu \mathrm{moles} / \mathrm{g})$}
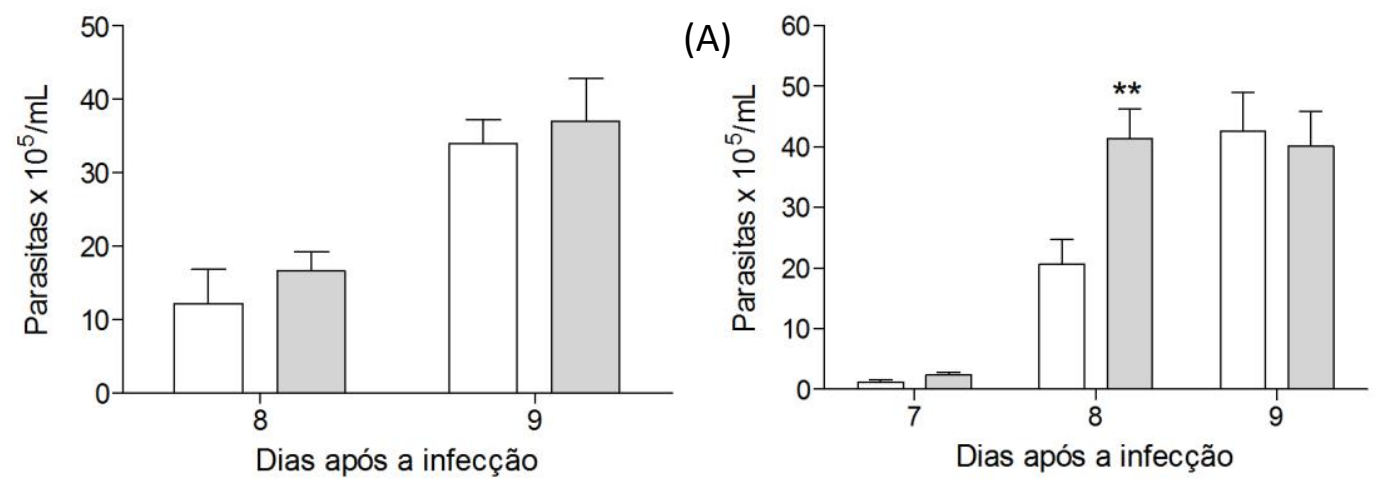

(B)
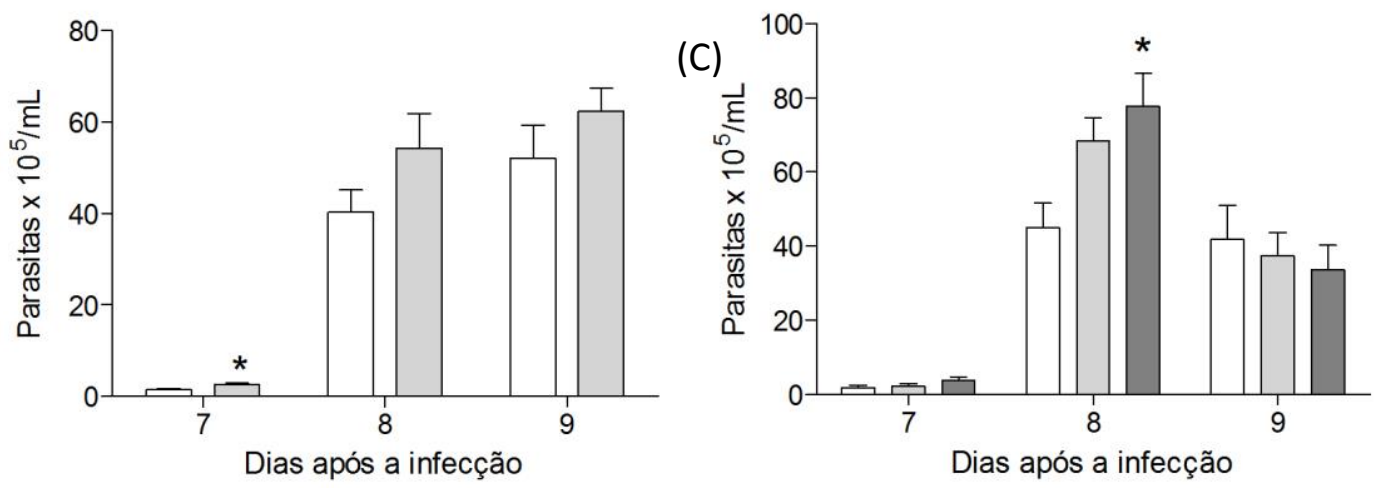

(D)
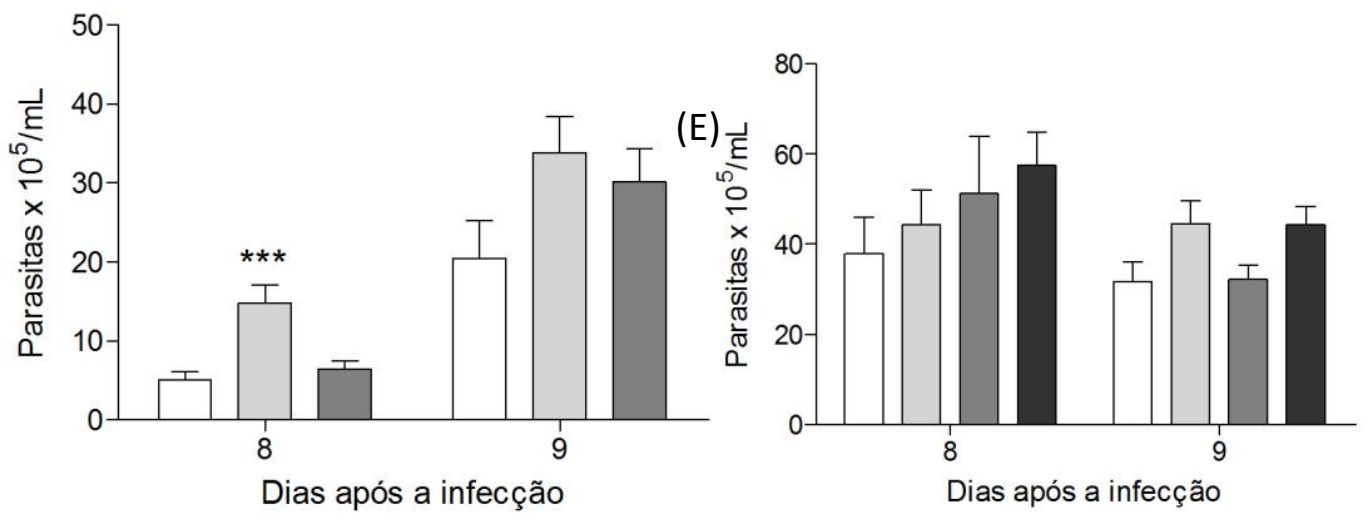

(F)

Figura 8 - Picos parasitêmicos de animais infectados e tratados com prolina. Seis experimentos independentes nos quais camundongos da linhagem BALB/c foram infectados por via i.p com 500 formas de tripomastigotas sanguícolas e tratados com diferentes doses de prolina durante 10 dias. A parasitemia foi avaliada no $7^{\circ}, 8^{\circ}$ e $9^{\circ}$ dias após a infecção (Brener, 1962) e suas médias e erros-padrão foram determinados. 
Além dos resultados dos tratamentos com prolina dos animais infectados serem pouco conclusivos em termos de parasitemia, o tratamento com prolina nas doses testadas não teve qualquer efeito sobre a mortalidade dos animais infectados (Figura 9).

$$
\begin{array}{ll}
\square \text { Controle } & \triangleleft \text { Pro }(18,2 \mu \text { moles } / \mathrm{g}) \\
\diamond \text { Pro }(14 \mu \mathrm{moles} / \mathrm{g}) & \diamond \text { Pro }(30 \mu \mathrm{moles} / \mathrm{g})
\end{array}
$$
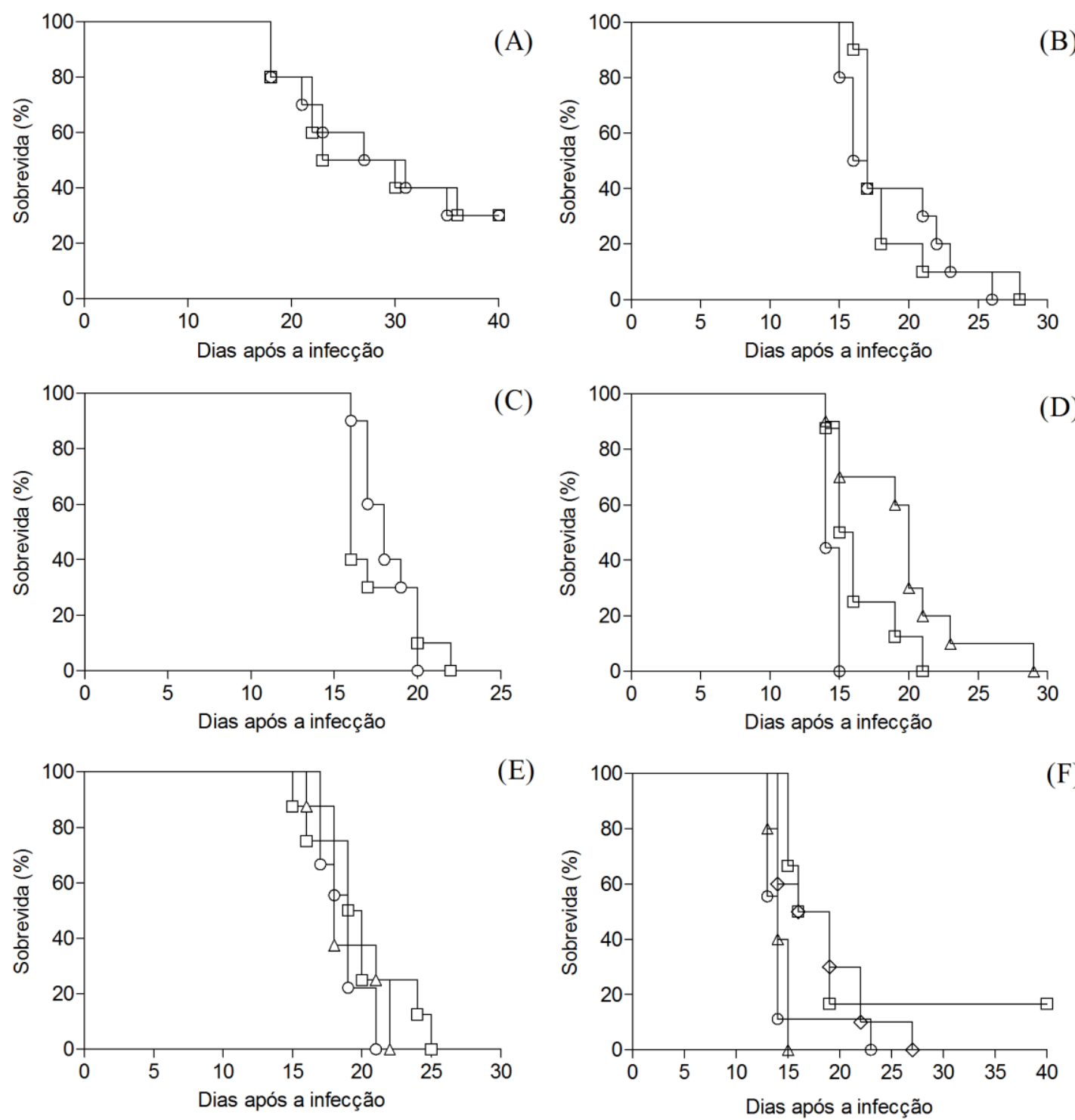

Figura 9 - Curvas de sobrevida de animais infectados e tratados com prolina. Seis experimentos independentes nos quais camundongos da linhagem BALB/c foram infectados por via i.p com 500 formas de tripomastigotas sanguícolas e tratados com diferentes doses de prolina durante 10 dias. A sobrevida foi monitorada durante 40 dias após a infecção. 
Embora os resultados fossem inconclusivos para o efeito esperado do tratamento com prolina sobre a parasitemia de camundongos, nós prosseguimos avaliando o efeito da hiperprolinemia transiente sobre a carga parasitária em diferentes tecidos. Diferenças na distribuição da carga parasitária em tecidos podem desempenhar um papel importante na patogenia da doença de Chagas. Trabalhos prévios demonstram a existência de cepas de $T$. cruzi com diferentes virulência e tropismos para diferentes tecidos (Andrade, Macedo, 1973; Bice, Zeledon, 1970; Campos, 1927; Hanson, Roberson, 1974; Melo, Brener, 1978; Taliaferro, Pizzi, 1955; Vianna, 1911). Portanto a avaliação da carga parasitária em determinados órgãos é um parâmetro importante para avaliar efeitos curativos ou de severidade da infecção. As análises histológicas não mostraram nenhuma diferença significativa na quantidade de ninhos de amastigotas no coração, músculo esquelético, intestino ou bexiga de animais tratados quando comparados aos controles (Figura 10). Não foi encontrada uma distribuição homogênea de ninhos de amastigotas no baço e pulmão, sendo muitas vezes, a média dos grupos controle menor que 1 ninho de amastigota em 20 campos microscópicos (aumento 400 x). Portanto, devido a essas condições, não foi possível a avaliação da carga parasitária nesses dois órgãos, por meio dessa metodologia. Esses resultados foram confirmados pela PCR quantitativa (PCRq) para os mesmos tecidos e também para o baço e pulmão (Figura 11, Tabela 2). O limite de detecção observado para PCRq foi de aproximadamente 0,5 parasita equivalente $/ 25 \mathrm{mg}$ de tecido, sendo compatível com os limites de detecção relatados na literatura (Cummings, Tarleton, 2003). 
Tabela 2 - Carga parasitária tecidual de animais infectados pelo T.cruzi e tratados com prolina.

\begin{tabular}{cccccc} 
Técnica & Tecido & Controle & $\begin{array}{c}\text { PRO } 14 \\
\mu \text { moles } / g\end{array}$ & $\begin{array}{c}\text { PRO 18,2 } \\
\mu \text { moles } / g\end{array}$ & $\begin{array}{c}\text { Valor de } \\
p\end{array}$ \\
\hline Histologia & Coração & $30,80 \pm 5,953$ & $34,20 \pm 19,39$ & $33,80 \pm 17,57$ & 0,9857 \\
Histologia & Musc. esquelético & $1,400 \pm 0,5099$ & $0,400 \pm 0,245$ & $1,600 \pm 0,5099$ & 0,1606 \\
Histologia & Intestino & $6,000 \pm 3,728$ & $2,00 \pm 2,00$ & $9,400 \pm 7,928$ & 0,6131 \\
Histologia & Bexiga & $194,8 \pm 41,36$ & $135,2 \pm 41,88$ & $183,6 \pm 42,62$ & 0,5801 \\
\hline PCRq & Coração & $2019 \pm 867,0$ & $2025 \pm 719,1$ & $1288 \pm 177,2$ & 0,6728 \\
$P C R q$ & Musc. esquelético & $299,5 \pm 123,1$ & $187,3 \pm 52,82$ & $92,05 \pm 17,71$ & 0,2246 \\
$P C R q$ & Intestino & $164,6 \pm 59,02$ & $298,6 \pm 105,8$ & $155,6 \pm 84,52$ & 0,4471 \\
$P C R q$ & Bexiga & $514,7 \pm 117,0$ & $487,1 \pm 61,36$ & $302,0 \pm 52,96$ & 0,1937 \\
$P C R q$ & Baço & $106,3 \pm 33,76$ & $102,6 \pm 4,15$ & $66,88 \pm 10,75$ & 0,3688
\end{tabular}
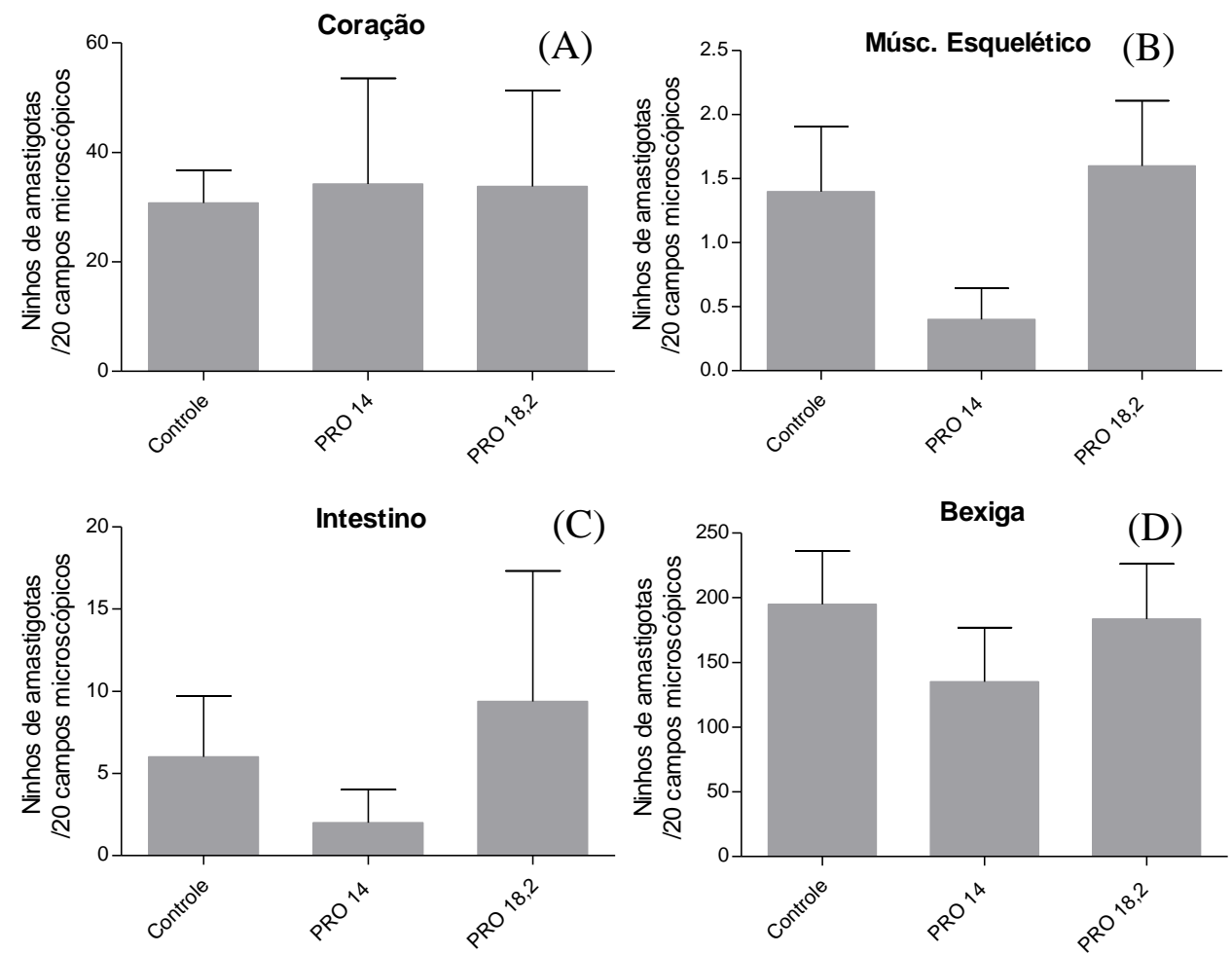

Figura 10 - Avaliação da carga parasitária tecidual por meio de técnica histológica. Camundongos da linhagem BALB/c foram infectados por via i.p com 500 formas de tripomastigotas sanguícolas e tratados com prolina durante 10 dias. As médias (+- SE) dos números de ninhos de amastigotas foram determinadas 15 dias após a infecção, em 4 tecidos, por meio de análise histológica (coloração Hematoxilina-Eosina). 

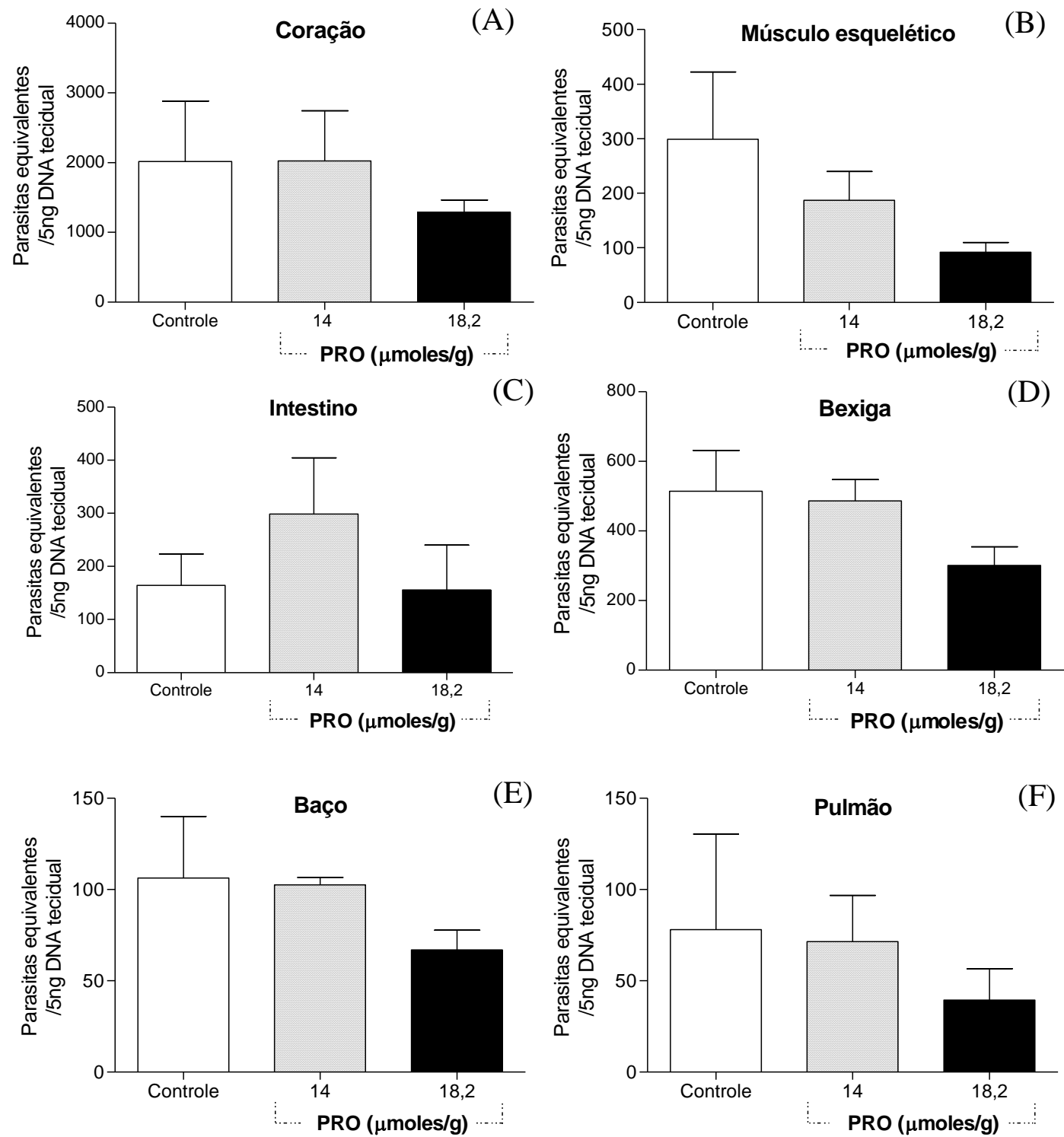

Figura 11 - Avaliação da carga parasitária tecidual por meio de PCRq. Camundongos da linhagem $\mathrm{BALB} / \mathrm{c}$ foram infectados por via i.p com 500 formas de tripomastigotas sanguícolas e tratados com prolina durante 10 dias. As médias (+- SE) de parasitas equivalentes a 5 ng de DNA tecidual foram determinadas 15 dias após a infecção, em 6 tecidos, por meio de PCR quantitativa.

\subsection{Efeito da suplementação de prolina no meio de cultura sobre o ciclo intracelular de}

\section{T. cruzi.}

Como o modelo experimental obtido aqui não mantém a alteração dos níveis de prolina na circulação ao longo do tempo, nós partimos para ensaios ex vivo, nos quais é possível controlar a disponibilidade de prolina. Foi avaliado o efeito da suplementação de prolina no meio de cultura de células peritoneais infectadas. Após 48 e 72 horas de cultivo na presença 
de diferentes concentrações de prolina, não foi observada nenhuma diferença na taxa de infecção e na quantidade de amastigotas por célula (Figura 12).

(A)

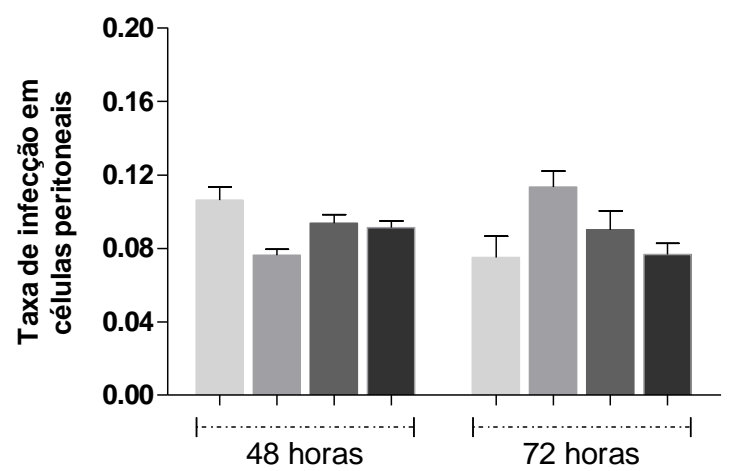

(B)

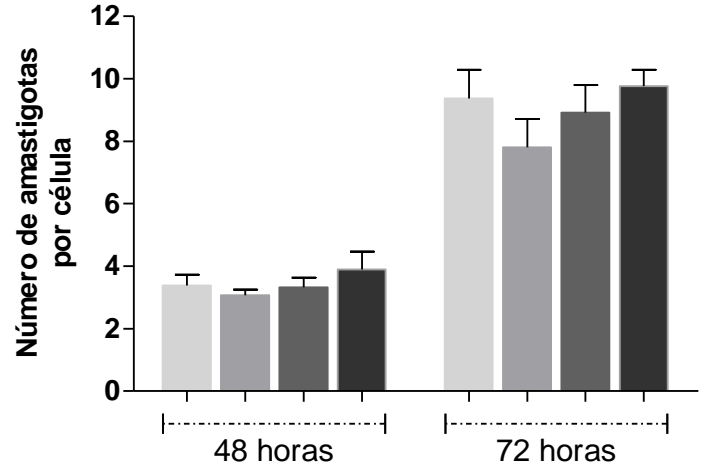

Figura 12 - Efeito da suplementação de prolina no estágio intracelular de $T$. cruzi em células peritoneais. Células peritoneais obtidas de camundongos da linhagem BALB/c foram cultivadas sobre lamínulas em placas de 24 poços numa densidade celular de $5 \times 10^{5}$ /poço. As células foram infectadas com tripomastigotas da cepa Y provenientes de infecções de $\mathrm{LLCMK}_{2}$ na presença de diferentes concentrações de prolina (razão de infecção 5:1). Após 48 ou 72 horas de infecção, as lamínulas foram coradas com Panótipo. Em (A) foi determinada a taxa de infecção, dividindo-se o número de células infectadas por 200 células contadas aleatoriamente e em (B) está representada a media do número de amastigotas por célula. A análise foi realizada utilizando-se o microscópio de luz. Os valores estão expressos em médias e desvios-padrão.

Surpreendentemente, durante a contagem de células no microscópio de luz, notou-se que células tratadas com $3 \mathrm{mM}$ de prolina apresentavam redução de 54,1\% da área celular em relação ao controle (Figura 13), o que deve ser interpretado como redução do volume celular. A média da área celular para as células controle foi de 106,9 $\pm 3,427 \mu \mathrm{m}^{2}$ enquanto que para camundongos tratados, a média foi de 49,02 $\pm 2,689 \mu \mathrm{m}^{2}$ (valor de $p<0,0001$ ). 


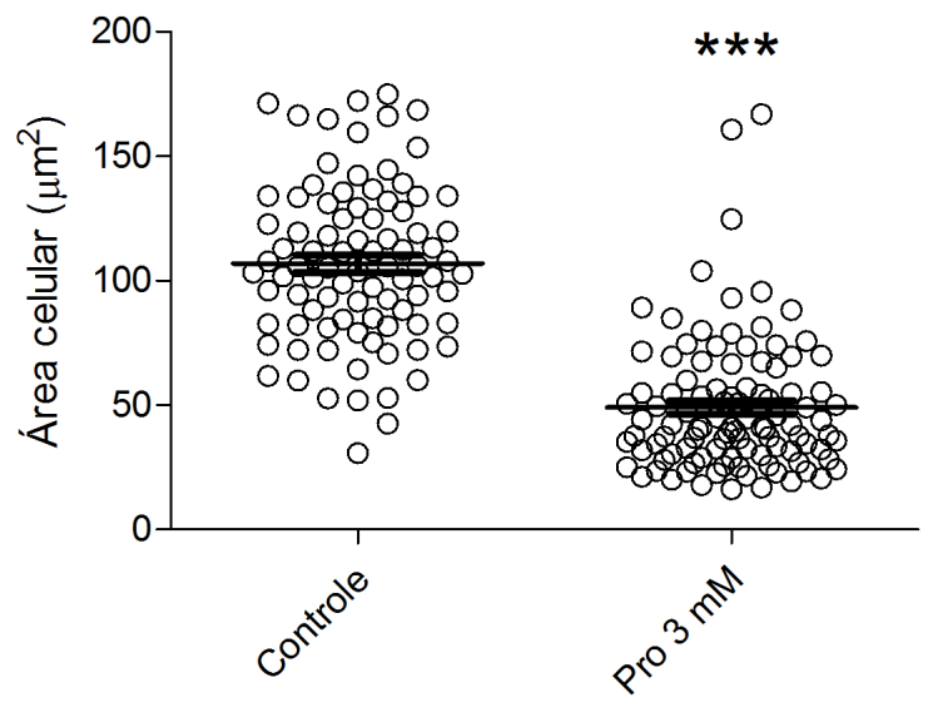

Figura 13 - Área celular $\left(\mu^{2}\right)$ de células peritoneais infectadas. Células peritoneais obtidas de camundongos da linhagem BALB/c foram cultivadas sobre lamínulas em placas de 24 poços, com densidade celular de $5 \times 10^{5} /$ poço e infectadas com tripomastigotas da cepa $\mathrm{Y}$, na presença de diferentes concentrações de prolina. Após 48 horas, as lamínulas foram coradas com panótipo e a área das células $\left(\mu \mathrm{m}^{2}\right)$ foi determinada utilizando o software computacional Image J. Aumento de 1000 x. $\mu^{2}$ : micrômetros quadrados. Os valores estão expressos em médias e desvios-padrão.

Foi levantada a hipótese de que altas concentrações de prolina reduz o volume de células peritoneais. Para corroborar este efeito, e analisar a sua relação com a infecção, foi repetido o ensaio em células não infectadas. Após 48 horas de incubação com o aminoácido, observamos mais uma vez uma redução significativa em seu volume (valor de $p=0,0017$, Figura 14). 

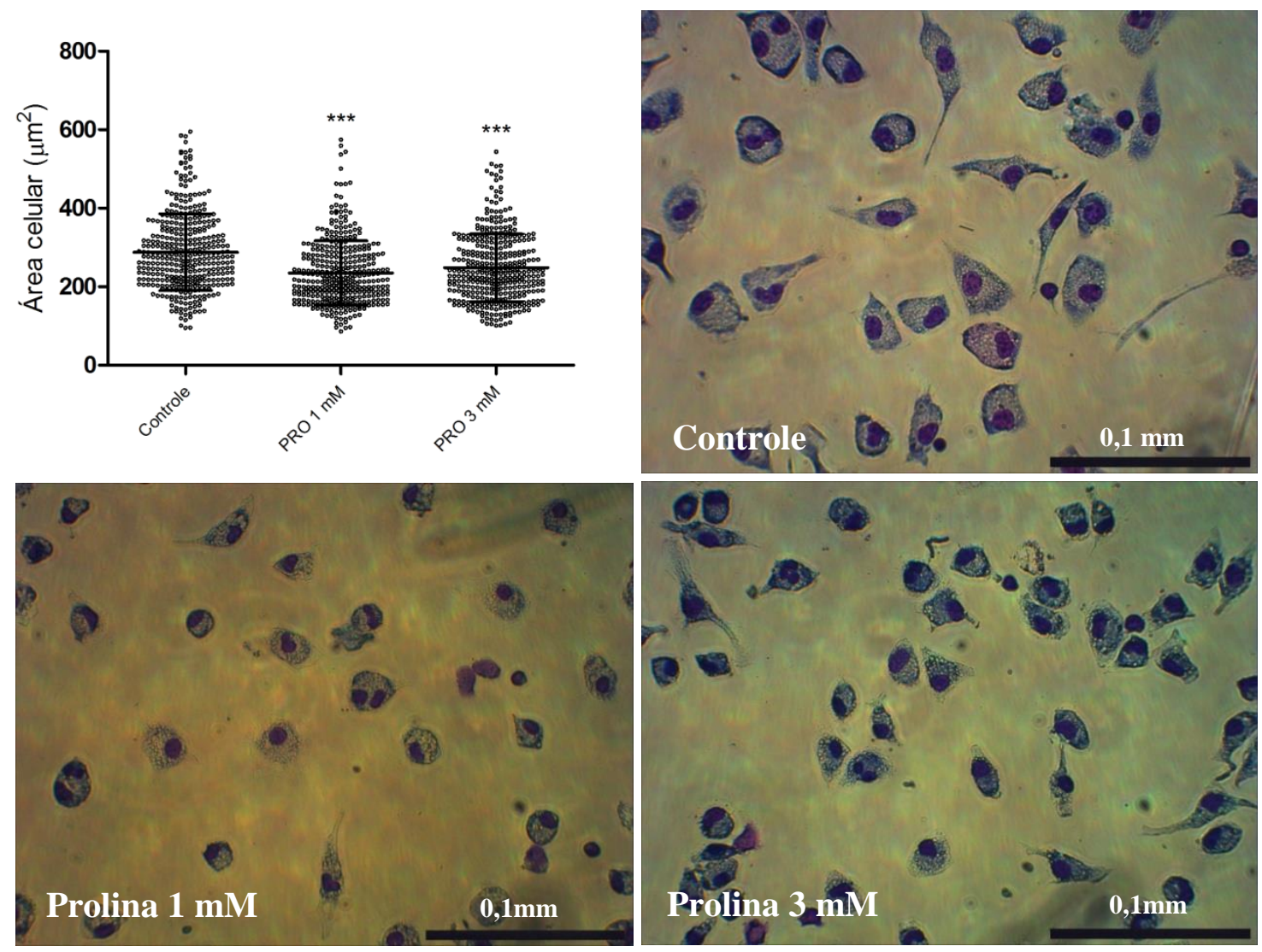

Figura 14 - Área celular $\left(\mu \mathrm{m}^{2}\right)$ de células peritoneais não infectadas. Céulas peritoneais obtidas de camundongos da linhagem BALB/c foram cultivadas sobre lamínulas em placas de 24 poços, com densidade celular de $5 \times 10^{5}$ /poço na presença de diferentes concentrações de prolina. Após 48 horas, as lamínulas foram coradas por Panótipo e a área das células $\left(\mu \mathrm{m}^{2}\right)$ foi determinada utilizando o software computacional Image J, Aumento de 400 x. $\mu \mathrm{m}^{2}$ : micrômetros quadrados. Os valores estão expressos em médias e desvios-padrão.

\subsection{Efeito da suplementação de prolina sobre alguns parâmetros da imunidade inata de células peritoneais}

Dados do nosso laboratório mostraram evidências de que a prolina é um fator relevante na biologia do parasita. Por outro lado, não podemos descartar a possibilidade de que a hiperprolinemia afete a resposta imune inata e por essa via interfira com severidade da infecção pelo T. cruzi. Sabe-se que, na imunidade inata os macrófagos produzem óxido nitrico (NO), uma molécula microbicida (De Groote, Fang 1995; Fang, 1997; Nathan, Shiloh, 2000) e que espécies reativas de nitrogênio e oxigênio derivadas dessas moléculas protegem o hospedeiro mamífero contra diversas infecções por patógenos intracelulares (Brunet, 2001; James, 1995; Murray, Nathan, 1999; Stenger et al., 1996; Vespa et al., 1994) incluindo T. cruzi (Cardoni et al., 1990; Gazzinelli et al. 1992; McCabe, Mullins, 1990; 
Nathan et al., 1979; Reed, 1988; Vespa et al., 1994; Vray et al., 1991). Baseado nisso, avaliou-se o efeito da suplementação de prolina no meio de cultura, sobre a geração de NO por células peritoneais (considerando que a maioria da população de células aderidas no poços seja composta por macrófagos). A fim de quantificar essa molécula pró-inflamatória, obtivemos um curva de regressão linear usando diferentes concentrações de nitrito que variaram entre 15 e $240 \mu \mathrm{M}$, com $r^{2}$ de 0,9997 , uma vez que o nitrito representa um produto indireto da geração de óxido nítrico (Figura 15).

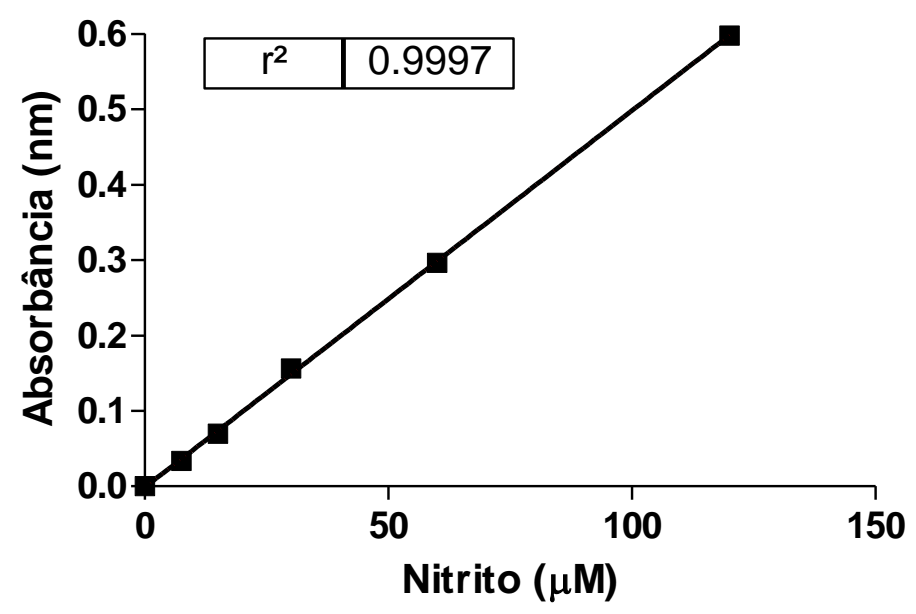

Figura 15 - Curva de regressão linear construída a partir de diferentes concentrações de nitrito $\left(\mathrm{NO}_{2}^{-}\right)$ produto indireto da geração de oxido nitrico. $\mathrm{O}$ reagente de Griess foi adicionado a diferentes concentrações de $\mathrm{NO}_{2}{ }^{-}$em placa de 96 pocos. A curva-padrão foi obtida pela leitura da placa em espectofotômetro em 515 nm.

Como mostrado abaixo (Figura 16), células estimuladas com $1 \mu \mathrm{g}$ de LPS e não infectadas apresentaram aumento de 60,4 \% na geração de óxido nítrico. No entanto, quando o estímulo por LPS somou-se ao estímulo da infecção das células a diferença foi de 87,9\% em relação ao controle (células não estimuladas por LPS e não infectadas). Por outro lado, quando $3 \mathrm{mM}$ de prolina foi adicionada ao meio de cultura de células estimuladas e infectadas, houve uma redução significativa na geração de NO com respeito a diferença de 87,9\%. Também não foi observada nenhuma diferença significativa entre células não estimuladas por LPS, tratados ou não com prolina. 


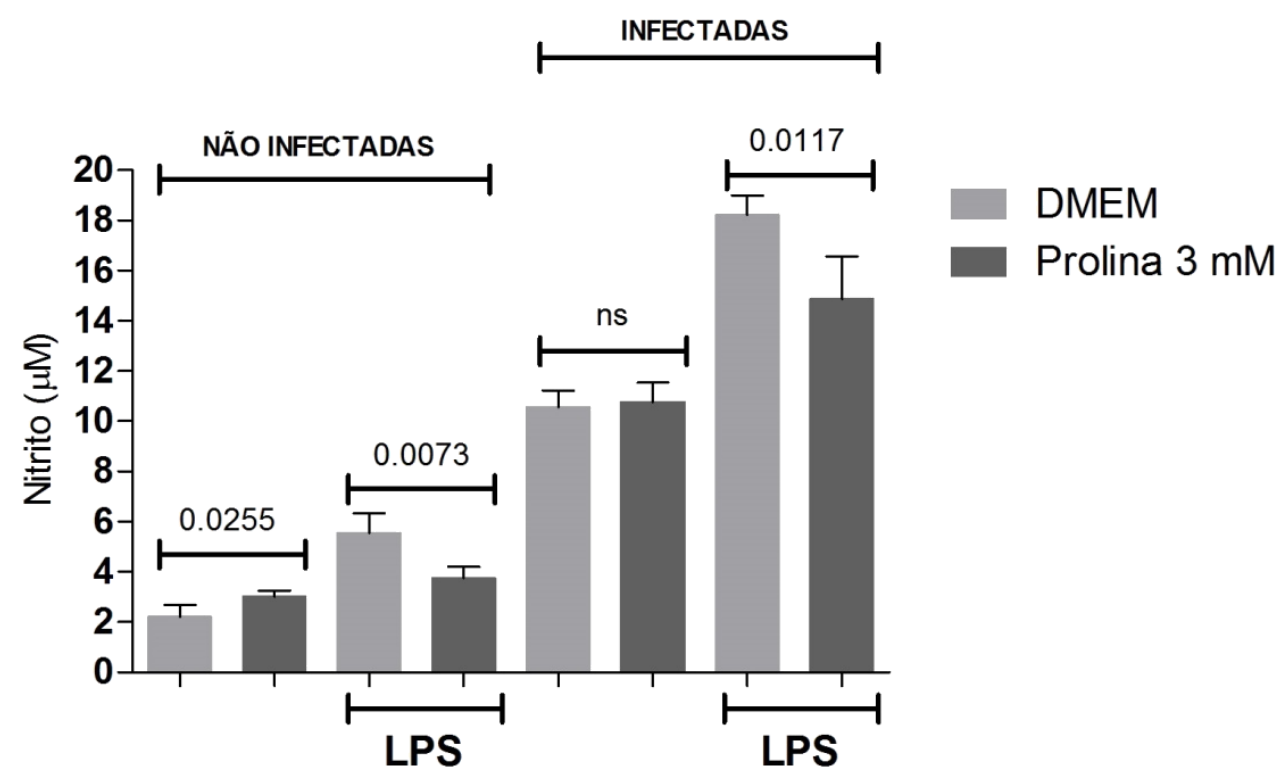

Figura 16 - Produção de óxido nítrico por células peritoneais cultivadas com prolina. Células peritoneais obtidas de camundongos da linhagem BALB/c foram cultivadas em placas de 96 poços com densidade celular de $1 \times 10^{6}$ /poço e infectadas, na presença ou ausência de $3 \mathrm{mM}$ de prolina sob estímulo ou não com $1 \mu \mathrm{g}$ de LPS por 48 horas. O reagente de Griess foi adicionado ao sobrenadante da cultura de células e os valores de absorbância foram determinados a $515 \mathrm{~nm}$. A concentração de $\mathrm{NO}_{2}{ }^{-}$foi determinada com referência a uma curva-padrão. Os valores estão expressos em médias e desvios-padrão.

Sabe-se que a disponibilidade da arginina é crucial para geração de NO. Pois se trata do substrato utilizado pela NOS induzível (iNOS) para gerar esse mediador pró-inflamatório (Iyengar et al., 1987; MacMicking et al., 1997) importante para o controle da infecção pelo T. cruzi (Cardoni et al., 1990, Vespa et al., 1994). Baseado nisso, avaliamos se o efeito da suplementação de prolina no meio de cultura sobre a geração de NO é arginina-dependente. O meio de cultura comercial DMEM possui em sua formulação $482 \mu \mathrm{M}$ de arginina, o que constituiu no experimento a concentração basal. As células submetidas a quantidades adicionais de arginina (concentração basal $+200 \mu \mathrm{M}$ ), suplementadas ou não com prolina, não apresentaram diferenças na geração de NO quando comparados ao controle (meio de cultura comercial). Também, não foi observada nenhuma diferença entre células estimuladas com LPS (Figura 17). 


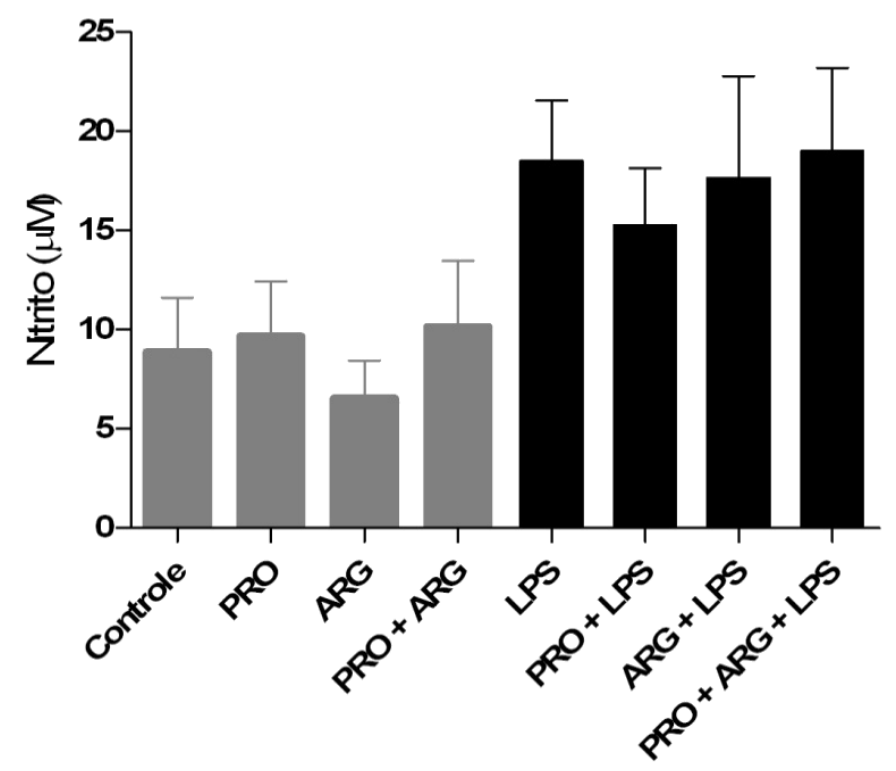

Figura 17 - Produção de óxido nítrico por células peritoneais na presença de prolina e arginina. Células peritoneais obtidas de camundongos da linhagem BALB/c foram cultivadas em placas de 96 poços com densidade celular de $1 \times 10^{6}$ /poço, na presença ou ausência de $3 \mathrm{mM}$ de prolina e/ou a adição de $200 \mu \mathrm{M}$ de arginina, sob estímulo ou não com $1 \mu \mathrm{g}$ de LPS durante 48 horas. $\mathrm{O}$ reagente de Griess foi adicionado ao sobrenadante da cultura de células e os valores de absorbância foram determinados a $515 \mathrm{~nm}$. A concentração de $\mathrm{NO}_{2}{ }^{-}$foi determinada com referência a uma curva-padrão. Os valores estão expressos em médias e desviospadrão.

Para garantir que a suplementação de prolina no meio de cultura não desencadeia em citotoxicidade, foi avaliada a viabilidade de células peritoneais cultivadas com diferentes concentrações de prolina. O ensaio de MTT mostrou que em todas as concentrações de prolina testadas, as células permanecem viáveis (Figura 18). Uma vez que a células peritoneas permanecem viáveis na presença de prolina, podemos concluir que qualquer efeito observado com o tratamento de prolina não se deve a uma possível citotoxicidade, que no final refletiria na quantidade de NO disponível no sobrenadante das células. 


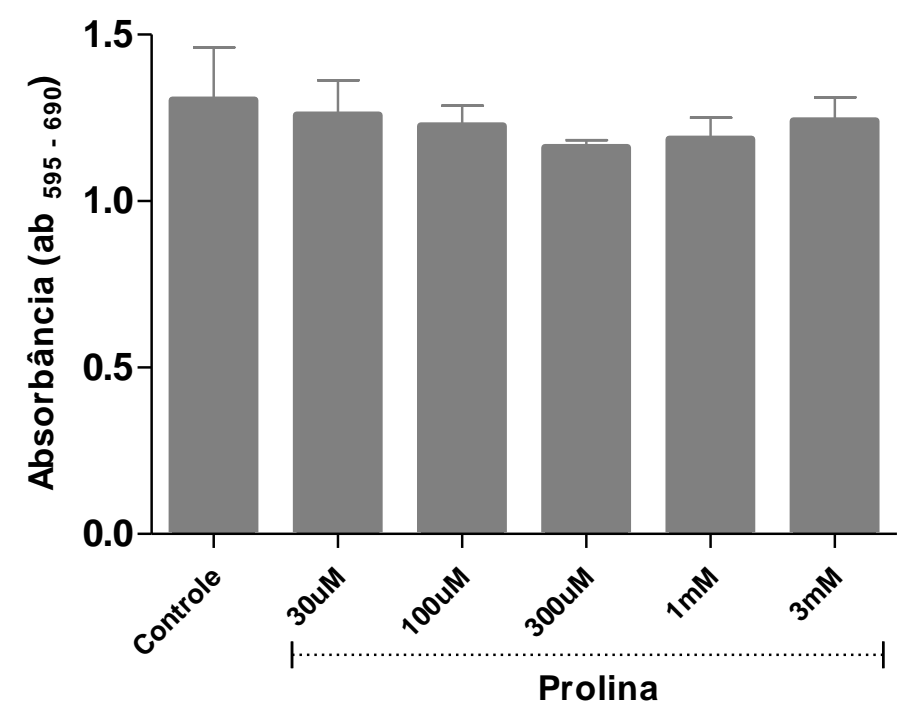

Figura 18 - Efeito da suplementação de prolina no meio de cultura sobre a viabilidade de células peritoneais. Células peritoneais obtidas de camundongos da linhagem $\mathrm{BALB} / \mathrm{c}$ foram cultivadas em placas de 24 poços com densidade celular de $5 \times 10^{5}$ /poço na presença de diferentes concentrações de prolina durante 48 horas. Após esse período o MTT foi adicionado ao lisado das células e os valores de absorbância foram determinados a 595-690 nm. Os valores estão expressos em médias e desvios-padrão.

Além da molécula microbicida NO, os macrófagos também produzem outras moléculas com ação pró-inflamátoria, como por exemplo, o fator de necrose tumoral alfa (TNF- $\alpha$ ). TNF- $\alpha$ é produzida durante uma inflamação aguda e é responsável por um gama diversa de eventos de sinalização dentro das células, levando a necrose ou apoptose (Idriss, Naismith, 2000). Por outro lado, os macrófagos também podem produzir moléculas imunossupressoras, como por exemplo, a interleucina (IL)-10 (Gordon, 2003; Merry et al., 2012). A IL-10 é uma das citocinas com propriedades anti-inflamatórias mais importantes, junto ao TGF- $\beta$. Ela é produzida por diferentes células do sistema imune, incluindo os macrófagos. A L-10 regula as funções de muitas células do sistema imune, diminui a produção de mediadores inflamatórios e inibe apresentação de antígenos (Sabat et al., 2010). Já o TGF- $\beta$ tem como função fundamental manter a tolerancia via regulação da proliferação de linfócitos, diferenciação e sobrevivência. Além disso, participa do controle da resposta inflamatória por meio da regulação da quimotaxia, ativação e sobrevivência de linfócitos, células NK, células dendríticas, macrófagos, mastócitos e granulócitos (Li et al., 2005). Baseado nisso avaliamos o efeito da suplementação de prolina sobre a expressão gênica de TNF- $\alpha$, IL-10, TGF- $\beta$ e também a óxido nítrico sintase induzível (iNOS - enzima 
responsável pela oxidação da arginina à citrulina na geração de óxido nítrico), em células peritoneais utilizando PCR quantitativa. Nós validamos os quatro pares de primers específicos, testando sua eficiência comparada com primers de actina- $\beta$ (ACT- $\beta$ ). Os quatro pares de primers geraram inclinações das retas de regressão com valores que sobrepõem ao valor obtido pela reta de regressão do normalizador, a ACT- $\beta$ (Figura 19, Tabela 3).

(A)

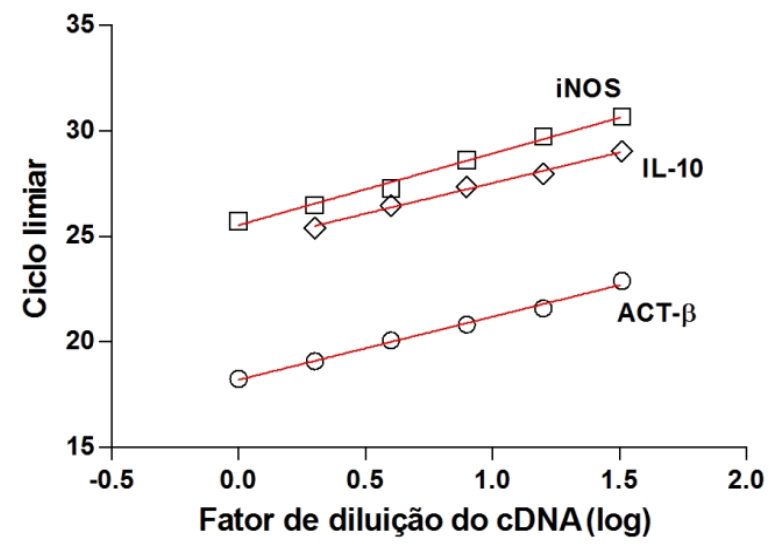

(B)

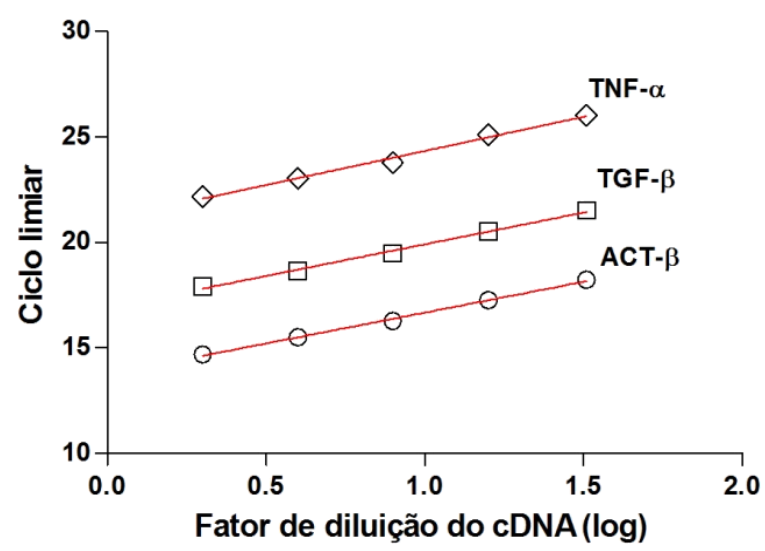

Figura 19 - Curvas de regressão linear utilizando diferentes primers murinos. As curvas de regressão linear foram construídas a partir de quantidades arbitrárias de RNAm diluído seriadamente, provenientes de células peritoneais. Os gráficos mostram os valores de $C t$ (eixo y) e fator de diluição do cDNA (eixo x) expresso em escala logarítmica. 
Tabela 3 - Valores de inclinação da curva, Y na origem e $\mathrm{R}^{2}$ obtidos com a construção da curva-padrão utilizando primers específicos para actina- $\beta$, iNOS, IL-10, TGF- $\beta$ e TNF- $\alpha$ murinos.

\begin{tabular}{|c|c|c|c|}
\hline Melhores valores de ajuste & Act $-\beta^{1}$ & iNOS & IL-10 \\
\hline Inclinação da reta de regressão & $2,986 \pm 0,1187$ & $3,388 \pm 0,1514$ & $2,896 \pm 0,1381$ \\
\hline$Y$ na origem, quando $X=0$ & $18,21 \pm 0,1081$ & $25,53 \pm 0,1379$ & $24,62 \pm 0,1378$ \\
\hline $\mathrm{X}$ na origem, quando $\mathrm{y}=0$ & $-6,097$ & $-7,535$ & $-8,503$ \\
\hline 1/inclinação da reta de regressão & 0,3348 & 0,2951 & 0,3453 \\
\hline \multicolumn{4}{|l|}{$95 \%$ intervalos de confiança } \\
\hline Inclinação da reta de regressão & 2,657 a 3,316 & 2,968 a 3,808 & 2,457 a 3,335 \\
\hline$Y$ na origem, quando $X=0$ & 17,91 a 18,51 & 25,15 a 25,91 & 24,19 a 25,06 \\
\hline $\mathrm{X}$ na origem, quando $\mathrm{y}=0$ & $-6,949$ a $-5,415$ & $-8,710$ a $-6,619$ & $-10,19$ a $-7,262$ \\
\hline \multicolumn{4}{|l|}{ Grau de Ajuste } \\
\hline $\mathrm{r}^{2}$ & 0,9937 & 0,9921 & 0,9932 \\
\hline Melhores valores de ajuste & Act $-\beta^{2}$ & TGF- $\beta$ & TNF- $\alpha$ \\
\hline Inclinação da reta de regressão & $2,918 \pm 0,07957$ & $2,998 \pm 0,1151$ & $3,225 \pm 0,1688$ \\
\hline Y na origem, quando $X=0$ & $13,76 \pm 0,0794$ & $16,91 \pm 0,1149$ & $21,10 \pm 0,1684$ \\
\hline$X$ na origem, quando $y=0$ & $-4,714$ & $-5,641$ & $-6,542$ \\
\hline 1/inclinação da reta de regressão & 0,3427 & 0,3336 & 0,3100 \\
\hline \multicolumn{4}{|l|}{$95 \%$ intervalos de confiança } \\
\hline Inclinação da reta de regressão & 2,665 a 3,171 & 2,631 a 3,364 & 2,688 a 3,763 \\
\hline Y na origem, quando $X=0$ & 13,50 a 14,01 & 16,54 a 17,28 & 20,56 a 21,64 \\
\hline $\mathrm{X}$ na origem, quando $\mathrm{y}=0$ & $-5,250$ a $-4,265$ & $-6,554$ a $-4,927$ & $-8,031$ a $-5,477$ \\
\hline \multicolumn{4}{|l|}{ Grau de Ajuste } \\
\hline $\mathrm{r}^{2}$ & 0,9978 & 0,9956 & 0,9919 \\
\hline
\end{tabular}

Uma vez validados os primers, o próximo passo foi definir a concentração de LPS que seria utilizada para a ativação das células peritoneais nos experimentos seguintes. Amostras de cDNA de células peritoneais cultivadas por 18 horas na presença de diferentes concentrações de LPS foram analisadas por PCRq. Foi observado que, como esperado, em todas as concentrações testadas, a expressão gênica de iNOS foi significantemente maior quando comparada às células não ativadas, apresentando dose-dependência com respeito a quantidade de LPS (Figura 20). Desta maneira, foi selecionado $100 \mathrm{ng}$ de LPS, como a concentração fixa para ativação das células peritoneais nos experimentos seguintes, com 98,4 vezes mais expressão gênica em comparação ao controle. 


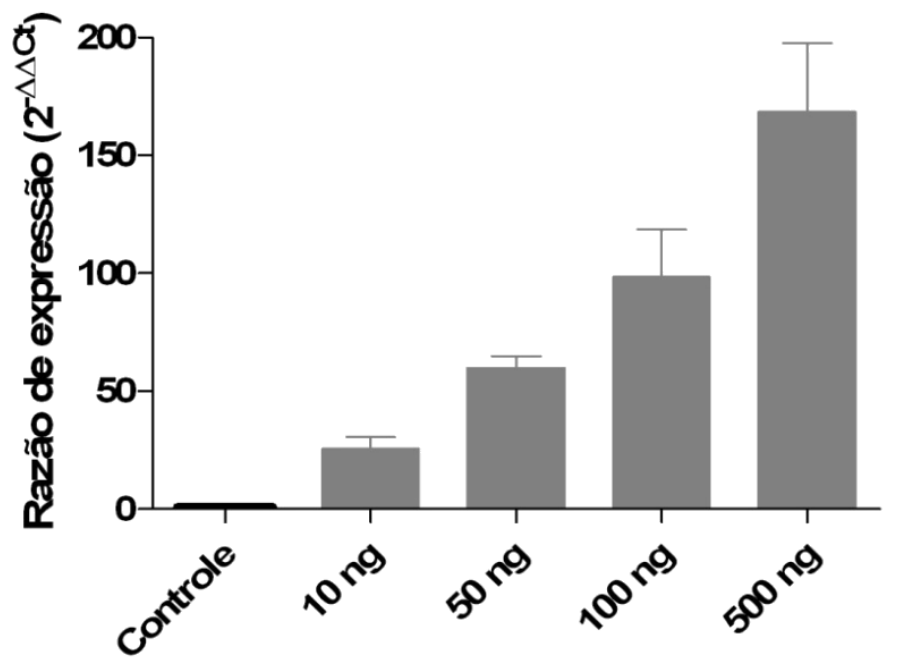

Figura 20 - Expressão gênica de iNOS em células peritoneais cultivadas com diferentes concentrações de LPS. Células peritoneais obtidas de camundongos da linhagem BALB/c foram cultivadas em placas de 6 poços com densidade celular de $2 \times 10^{6} /$ poço, na presença de diferentes concentrações de LPS durante 18 horas. O RNA total das células foi extraído para síntese de cDNA e analisado por PCR quantitativa. Os valores estão expressos em médias e desvios-padrão.

A expressão gênica de iNOS foi avaliada em células peritoneais cultivadas com diferentes concentrações de prolina e estimuladas por LPS. O tratamento dessas células diminuiu significantemente a expressão gênica de iNOS em ambas concencentrações de prolina (valor de $p=0,0002$, Figura $21 \mathrm{~A}$ ), no entanto não alterou a expressão gênica dos mediadores pró-inflamatório TNF- $\alpha$ e anti-inflamatórios IL-10 e TGF- $\beta$ (Figura 21 B, C e D). Esses dados corroboram com a redução da produção de NO em células tratadas com prolina e confirmam um papel imunossupressor. 
(A)
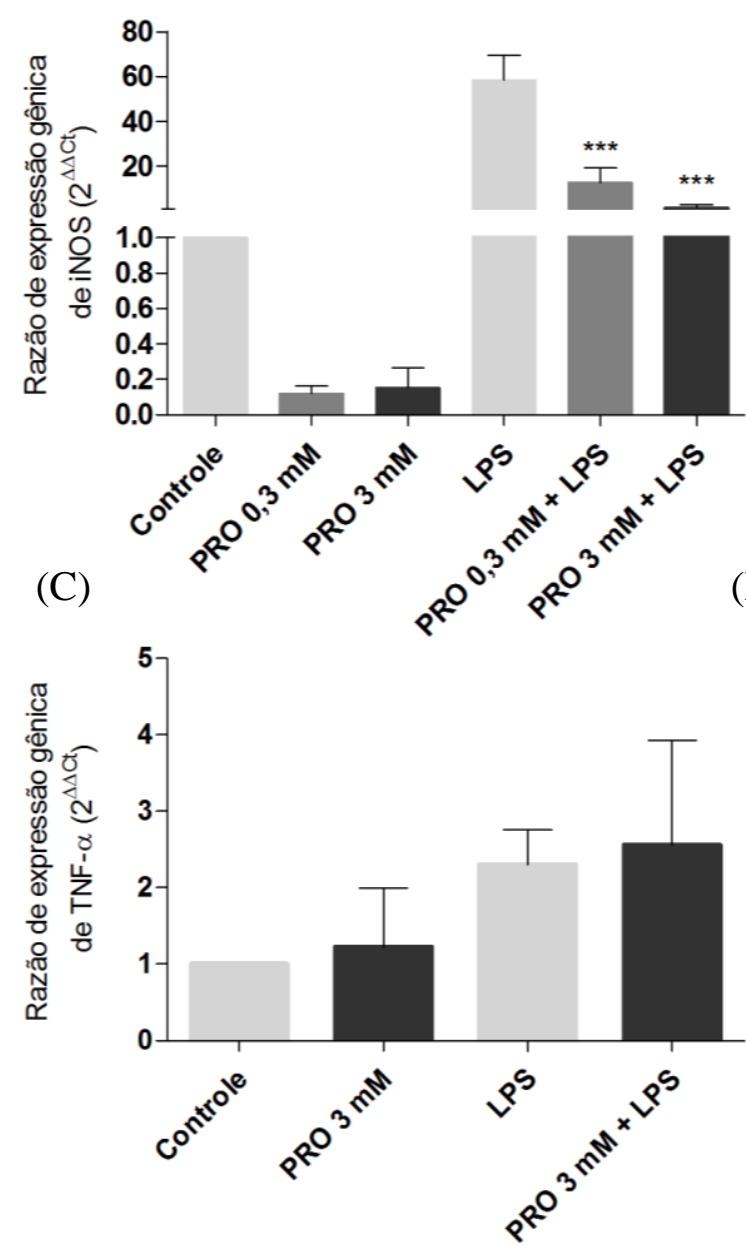

(B)

(D)
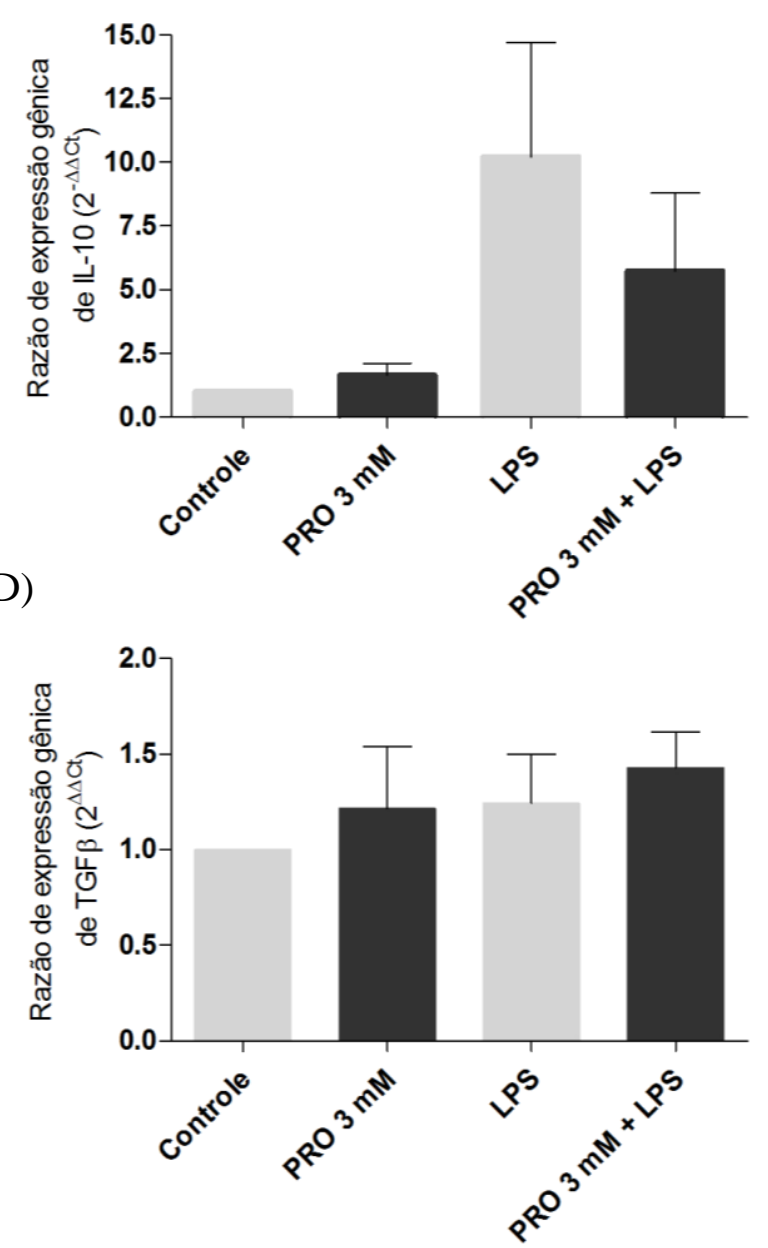

Figura 21 - Expressão gênica de mediaores pró- e anti-inflamatórios em células peritoneais cultivadas com diferentes concentrações de prolina. Células peritoneais obtidas de camundongos da linhagem BALB/c foram cultivadas em placas de 6 poços com densidade celular de $2 \times 10^{6}$ /poço, na presença de diferentes concentrações de prolina, com ou sem estímulo por LPS, durante 18 horas. O RNA total das células foi extraído para síntese de cDNA e analisado por PCR quantitativa. Os valores nos gráficos foram determinados pela fórmula $2^{\Delta \Delta \mathrm{Ct}}$ quando todos os valores representam médias da razão de expressão gênica sobre o valor obtido pelo controle, bem como seus desvios-padrão. Expressão gênica de iNOS em (A), IL-10 em (B), TNF$\alpha$ em (C) e TGF- $\beta$ em (D).

\subsection{Efeito da prolina sobre o ciclo intracelular de cepas de $T$. cruzi superexpressoras do transportador de prolina e sobre a infecção in vivo}

Em epimastigotas de $T$. cruzi, dois sistemas de transporte de prolina foram caracterizados bioquimicamente (Silber et al., 2002). Recentemente, Sayé et al. (2014) demonstraram que epimastigotas das cepas MJL e Y que superexpressam um desses tranportadores (TcAAAP069), apresentam maior taxa de transporte e como consequência, um aumento da concentração de prolina intracelular. Essa linhagem apresenta uma série de características relacionadas à superexpressão desse transportador: maior resistência às 
drogras tripanocidas Nifurtimox e Benzonidazol, e maior resistência a espécies reativas de oxigênio incluindo peróxido de hidrogênio e óxido nítrico. Essas cepas foram cedidas a nosso laboratório no contexto de uma colaboração em andamento entre ambos grupos, com o objetivo de avaliar ex vivo e in vivo parâmetros de infecção associados à superexpressão do transportador TcAAAP069.

Após a diferenciação das formas epimastigotas em tripomastigotas metacíclicos, montamos um ensaio ex vivo no qual avaliamos o efeito da suplementação de prolina sobre a infecção de células peritoneais cultivadas em placas de cultura. Foi observado que células infectadas com formas tripomastigotas da cepa MJL TcAAAP069 apresentam um aumento significativo da taxa de infecção quando comparadas às células infectadas com tripomastigotas expressando GFP (controle), após 48 ou 72 horas d.p.i (valor de $p$ para 72 horas $=0,0068$ ). Por outro lado, células infectadas com formas tripomastigota da cepa $\mathrm{Y}$ TcAAAP069 apresentaram uma redução na taxa de infecção quando comparamos a células controle (Y GFP), sendo que, apenas em 72 horas d.p.i essa diferença foi estatisticamente significativa (valor de $p=0,0004$ ) (Figura $22 \mathrm{~A}$ ). Todos esses dados sugerem que a redução ou o aumento da taxa de infeção em função da concentração de prolina é cepa-dependente. O número de amastigotas por célula também foi determinado. Não houve diferenças entre os grupos em nenhuma das cepas avaliadas (Figura 22 B). Porém deve-se salientar que foi obsevado uma grande dispersão nos dados obtidos devido a uma possível heterogeneidade na população celular aderida às placas. 
(A)

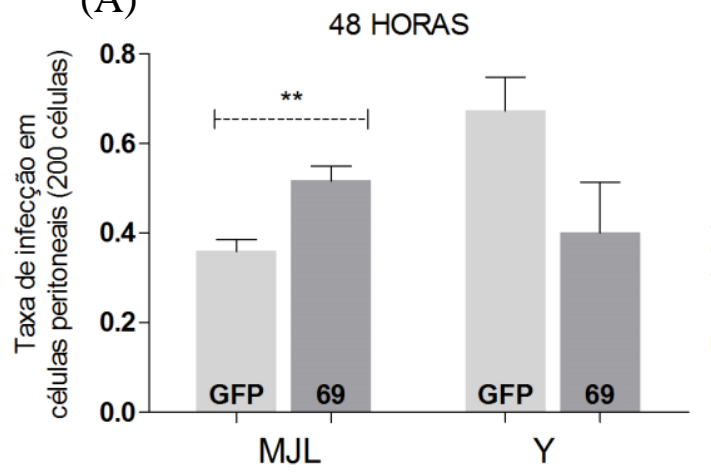

(B)

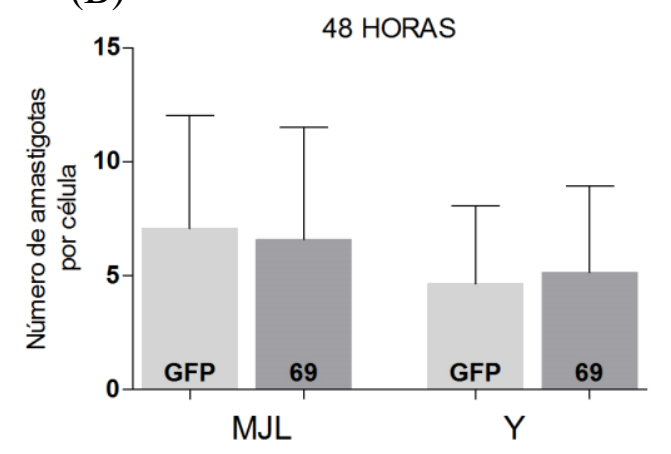

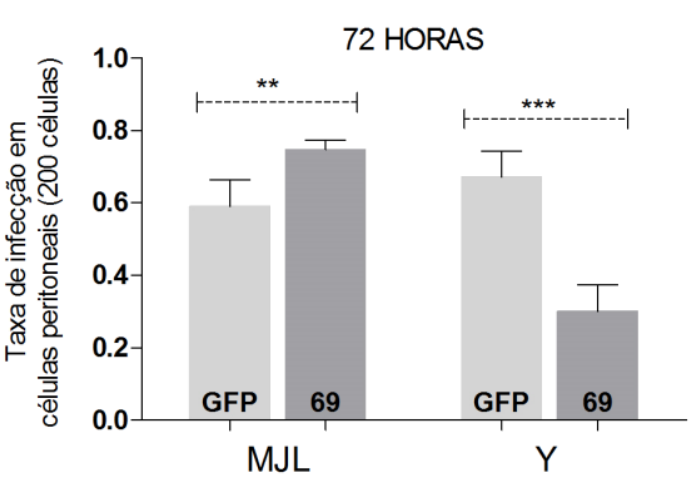

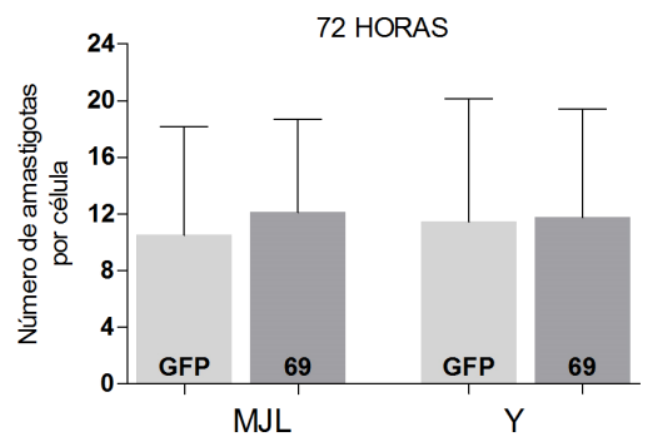

Figura 22 - Efeito da suplementação de prolina no estágio intracelular das cepas MJL e Y de T. cruzi que superexpressam o transportador de prolina TcAAAP069, em células peritoneais. Células peritoneais obtidas de camundongos da linhagem BALB/c foram cultivadas sobre lamínulas em placas de 24 poços numa densidade celular de $5 \times 10^{5}$ /poço. As células foram infectadas com tripomastigotas da cepa Y e MJL provenientes de infecções de $\mathrm{LLCMK}_{2}$ na presença de diferentes concentrações de prolina (razão de infecção 5:1). Após 48 ou 72 horas de infecção, as lamínulas foram coradas com Panótipo. Em (A) foi determinada a taxa de infecção, dividindo-se o número de células infectadas por 200 células contadas aleatoriamente e em (B) o número de amastigotas por células, utilizando-se o microscópio de luz. Tripomastigotas transfectados com a proteína GFP constituíram o controle do experimento. Os valores estão expressos em médias e desvios-padrão.

Para avaliar possíveis diferenças na infecção in vivo utilizando parasitas transfectados, camundongos da linhagem $\mathrm{BALB} / \mathrm{c}$ foram infectados por tripomastigotas transfectados provenientes de células $\mathrm{LLCMK}_{2}$ com a construção contendo o gene TcAAAP069 ou GFP (controle). Os camundongos BALB/c infectados por tripomastigotas sanguícolas da cepa Y superexpressores do transportador de prolina TcAAAP069 não apresentaram diferenças na parasitemia e nem na mortalidade com respeito aos camundongos controle (Figuras 23 e 24). 


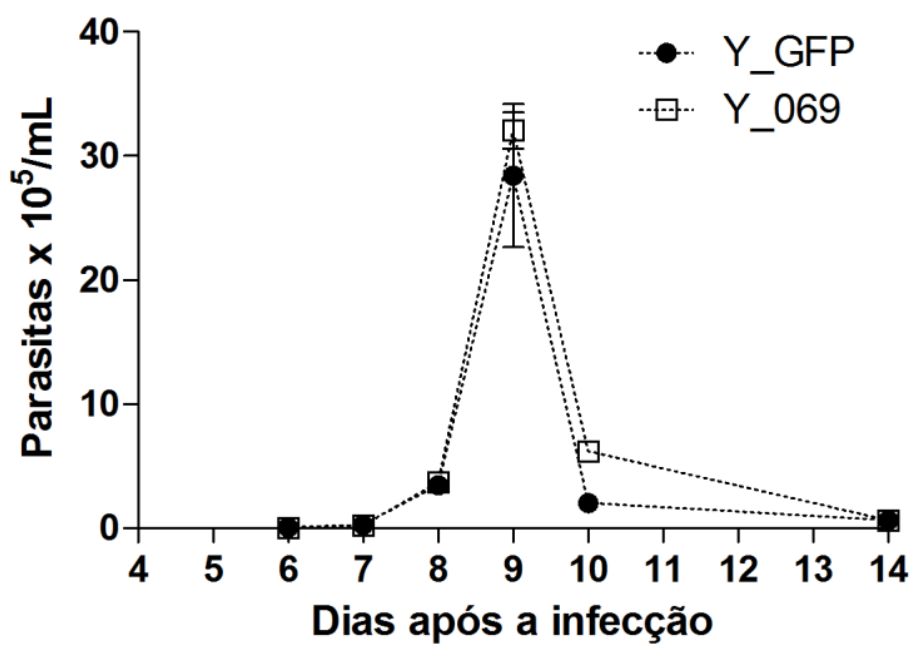

Figura 23 - Acompanhamento da curva de parasitemia em fêmeas de camundongos da linhagem BALB/c infectados com as cepa Y superexpressora do transportador de prolina TcAAAP069. Os animais foram infectados com 1000 formas de tripomastigotas sanguícolas da cepa Y de T. cruzi. A parasitemia foi acompanhada a partir do $5^{\circ}$ ao $18^{\circ}$ d.p.i por meio do método de Brener, 1962. Os valores estão expressos em médias e erros-padrão.

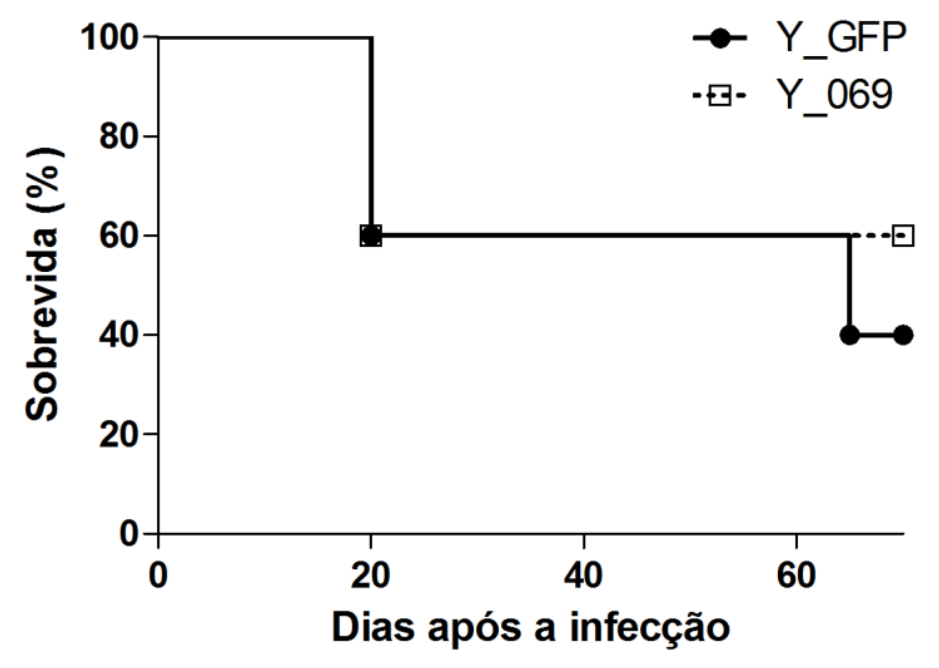

Figura 24 - Curvas de sobrevida de fêmeas de camundongos da linhagem BALB/c infectados pela cepa Y de $\boldsymbol{T}$. cruzi superexpressora do transportador de prolina TcAAAP069. Os animais foram infectados com 1000 formas de tripomastigotas sanguícolas da cepa Y de T. cruzi. A sobrevida foi acompanhada durante 40 dias após a infecção. Os valores estão expressos em médias e erros-padrão.

O efeito do tratamento com prolina também foi avaliado na infecção de camundongos da linhagem C57BL/6. Assim como camudongos da linhagem BALB/c, a linhagem C57BL/6 também apresenta picos parasitêmicos que variam entre $8^{\circ}$ e $9^{\circ}$ d.p.i. Animais que receberam prolina (18 $\mu$ moles/g) por via i.p não apresentaram diferenças em sua parasitemia 
quando comparados ao grupo controle (Figura 25). Também não vimos efeito do tratamento sobre a mortalidade desses animais (Figura 26).

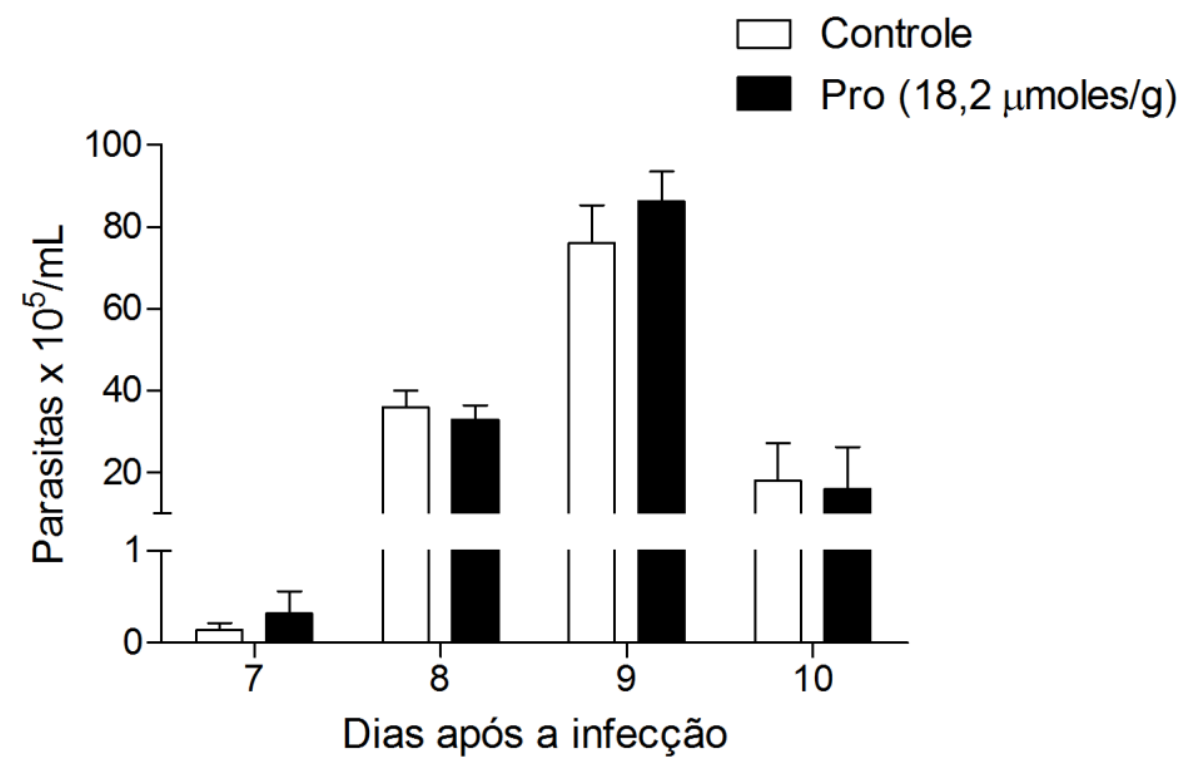

Figura 25 - Acompanhamento da parasitemia em camundongos da linhagem C57BL/6 infectados e tratados com prolina. Os animais foram infectados com 1000 formas de tripomastigotas sanguícolas da cepa Y de T. cruzi e tratados com $18 \mu$ moles/g de prolina ou PBS por via i.p. A parasitemia foi acompanhada entre o $7^{\circ}$ e $10^{\circ}$ d.p.i por meio do método de Brener (1962). Os valores estão expressos em médias e erros-padrão.

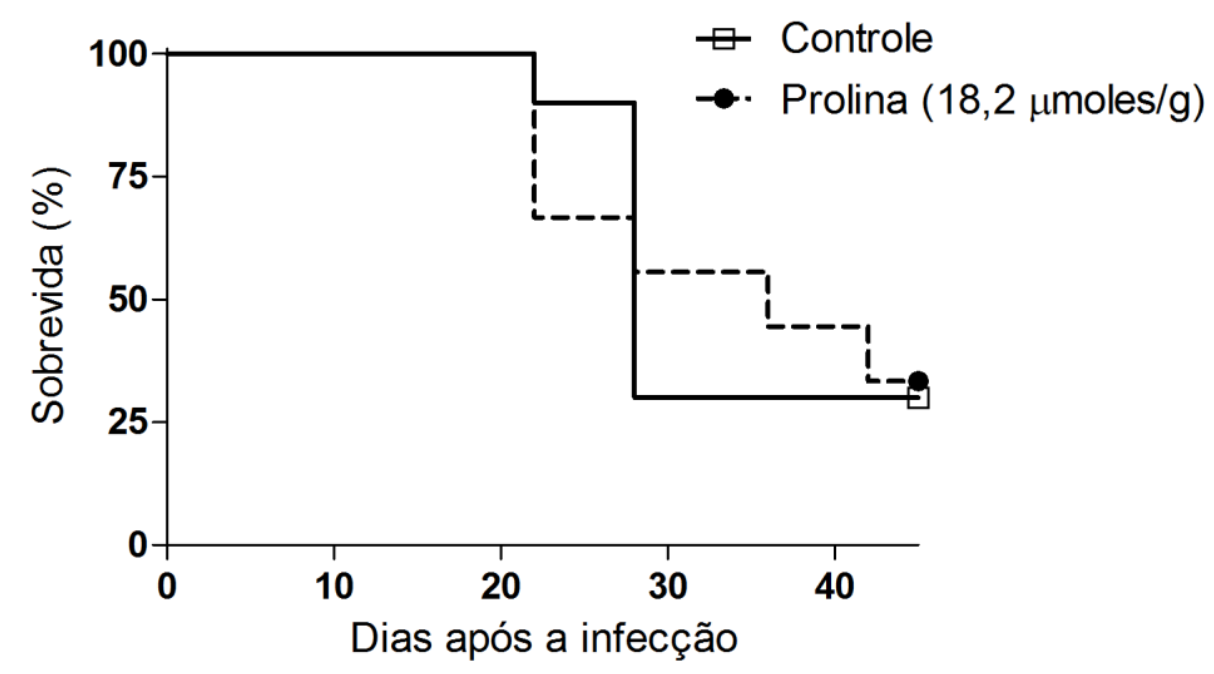

Figura 26 - Acompanhamento da sobrevida de camundongos da linhagem C57BL/6 infectados e tratados com prolina. Os animais foram infectados com 1000 formas de tripomastigotas sanguícolas da cepa Y de $T$. cruzi e tratados com $18 \mu$ moles/g de prolina ou PBS por via i.p. A sobrevida foi acompanhada até o $45^{\circ}$ d.p.i. Os valores estão expressos em médias e erros-padrão. 


\subsection{O modelo genético de hiperprolinemia e os efeitos da infecção pelo $T$. cruzi}

Tendo em vista a dificuldade em construir um modelo de hiperprolinemia em camundongos das linhagens BALB/c e C57BL/6, utilizamos como alternativa um camundongo transgênico que acumula prolina naturalmente, o PRO/ReJ. Este camundongo cujo fundo é C57BL/6 é deficiente para atividade da enzima prolina desidrogenase (PRODH), a primeira enzima da via de degradação da prolina e, portanto, acumula prolina no sangue, sendo essa diferença de até sete vezes quando comparada ao camundongo selvagem (Blake, Russell, 1972). Camundongos PRO/ReJ possuem hiperprolinemia tipo I uma desordem metabólica autossômica recessiva que é decorrente da presença de um alelo anormal localizado no locus designado pro-1 (Blake et al., 1976).

Obtivemos dois casais PRO/ReJ da companhia The Jackson Laboratory, no entanto apenas um macho estava viável para reprodução. Iniciamos o processo de recuperação da linhagem mutante e expansão da colônia. O único macho disponível foi acasalado com fêmeas selvagens C57BL/6. As fêmeas nascidas que correspondem a geração F1 foram acasaladas com o mesmo macho parental PRO/ReJ. E portanto, todos os animais nascidos desse cruzamento, que constitui a geração F2, foram genotipados para formação de casais homozigóticos recessivos. Seus descendentes que corresponde a geração F3 constituiu 100\% de camundongos da linhagem PRO/ReJ (Figura 27). Animais nascidos da geração F3 foram utilizados para formação de novos casais e, portanto à expansão da colônia ou para ensaios de infecção. 


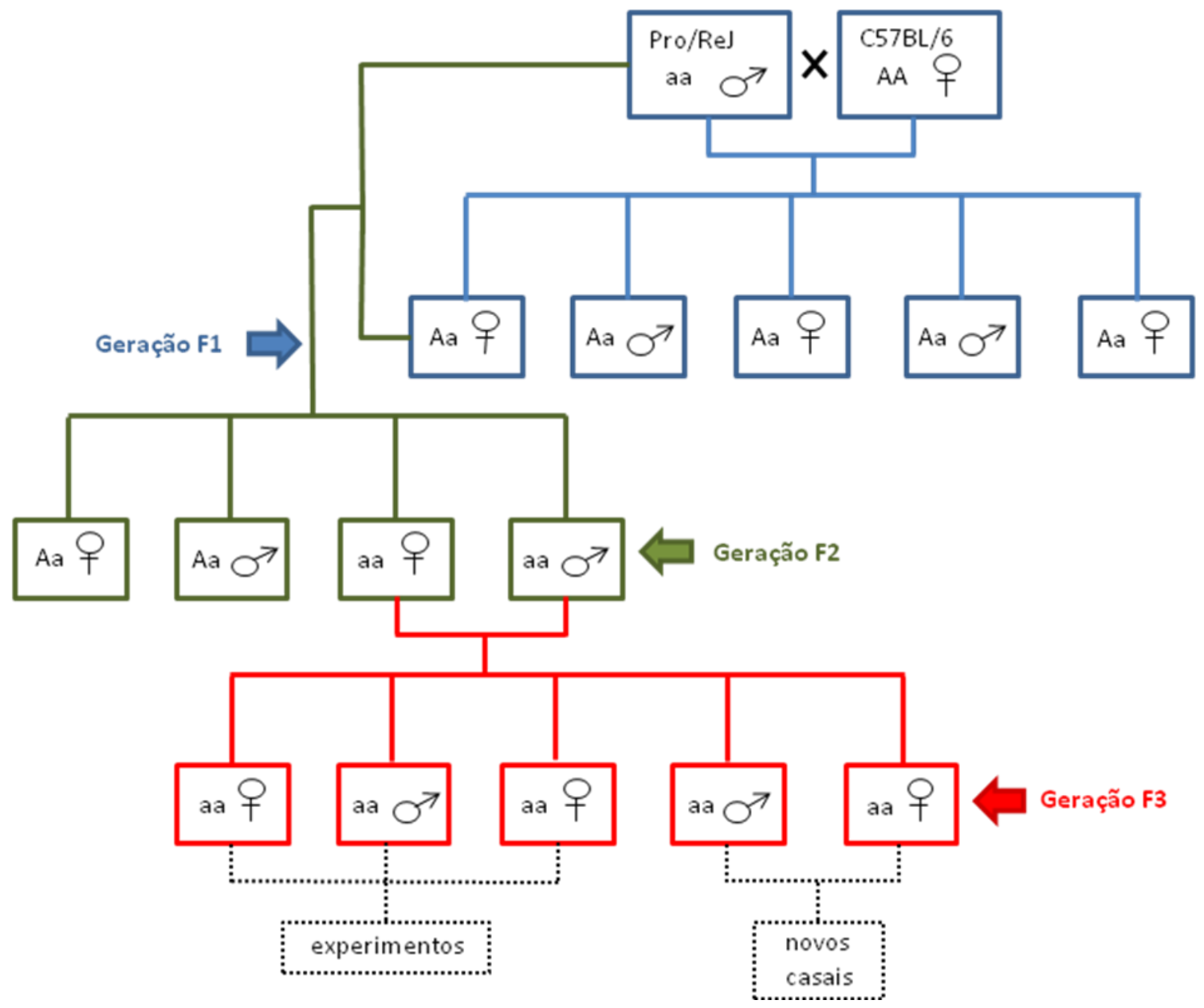

Figura 27 - Esquema de cruzamento para seleção de camundongos mutantes PRO/ReJ. O macho mutante PRO/ReJ adquirido da companhia The Jackson Laboratory foi acasalado com uma fêmea selvagem (C57BL/6), este casal representou a linhagem parental. Uma fêmea da geração F1, constituída de 100 \% de camundongos heterozigóticos, foi acasalada com o macho homozigótico parental PRO/ReJ. Camundongos homozigóticos nascidos na geração F2 foram acasalos entre si, gerando F3, constuída por $100 \%$ de homozigóticos. Camundongos da geração F3 foram acasalados entre si ou com o macho da linhagem parental. Os animais restantes foram utilizados nos experimentos de infecção.

Camundongos da linhagem C57BL/6 (selvagem) possuem dois sítios de corte para enzima de restriçaõ MnlI localizados no gene PRODH, enquanto que, a linhagem PRO/ReJ possui uma mutação em PRODH do qual tem um nucleotídeo G substuído por T que elimina um sítio de corte para MnlI (Gogos et al., 1999). Essa informação foi utilizada para genotipar a geração F2. Após corte com MnlI do fragmento amplificado e corrida em gel de agarose, é possível diferenciar heterozigóticos de homozigóticos recessivos pela quantidade e tamanho de bandas. A identificação dos camundongos heterozigóticos foi evidenciada em gel de agarose, no qual, como esperado para essa linhagem, foram reveladas quatro bandas 
com tamanhos de 34, 63, 117 e 180 pares de bases, enquanto que os homozigóticos recessivos apresentaram dois tamanhos de bandas, 34 e 180 pares de bases (Figura 28).

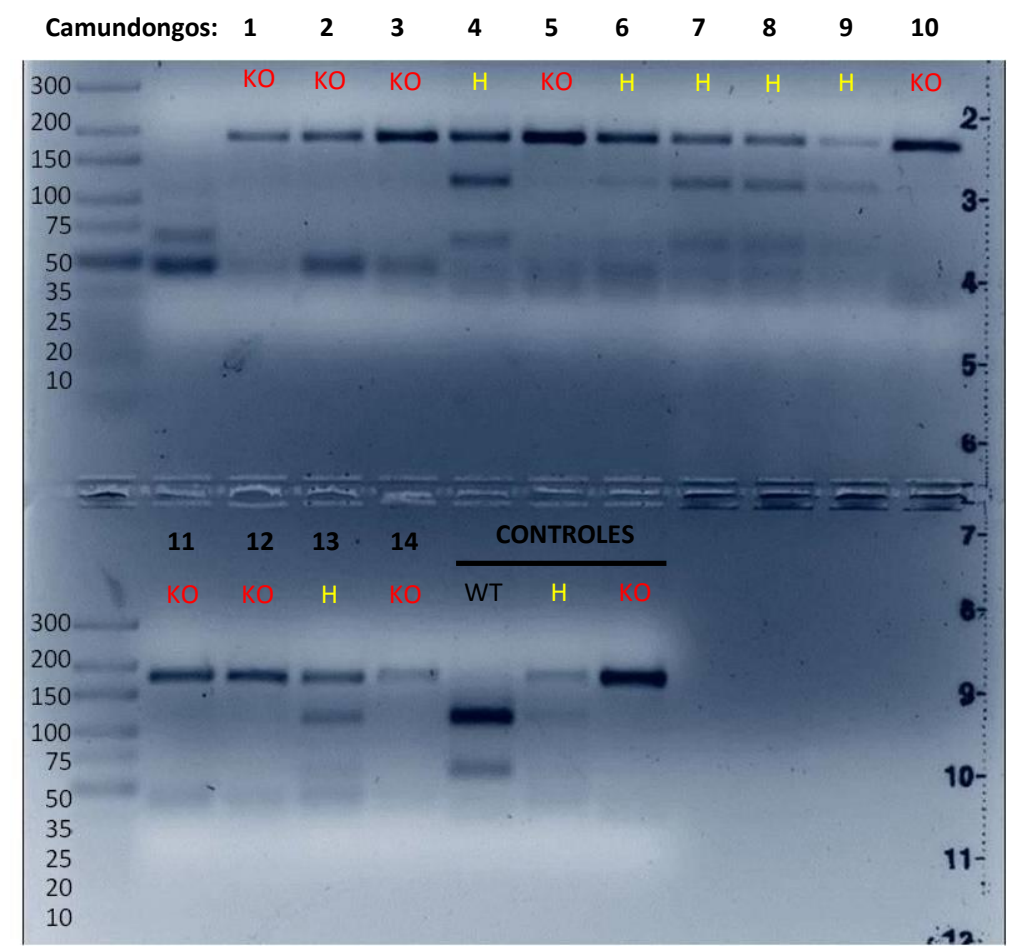

Figura 28 - Genotipagem da geração F2 para seleção de camundongos mutantes PRO/ReJ. Amostras de DNAg de camundongos nascidos com o cruzamento de macho PRO/ReJ e fêmea heterozigótica, foram analisadas por PCR utilizando primers específicos para a região de mutação no genoma. Em seguida os fragmentos foram submetidos a cortes com a enzima de restrição Mnll e após corrida em gel de agarose 4\% pelo processo de eletroforese foi possível vizualizar diferentes padrões de bandas que correspondem aos camundongos heterozigóticos ou homozigóticos mutantes. Um camundongos heterozigótico apresenta um padrão de bandas de 34, 63, 117 e 180 pares de bases enquanto que para um mutante homozigótico o padrão de banda é de 34 e 180 pares de bases. KO: nocaute para PRODH; H: heterozigótico; WT: selvagem.

Após o nascimento e genotipagem dos camundongos $\mathrm{PRO} / \mathrm{ReJ}$, o próximo passo foi validar o modelo avaliando seus níveis de prolina plasmática. Os camundongos PRO/ReJ apresentaram concentrações plasmáticas de 1,466 $\pm 0,014 \mathrm{mM}$, duas vezes maiores que camundongos selvagens $(0,7376 \mathrm{mM} \pm 0,022)$. Já, a concentração plasmática em camundongos heterozigóticos foi de $1,117{ }^{ \pm} 0,45 \mathrm{mM}$ (Figura 29). 


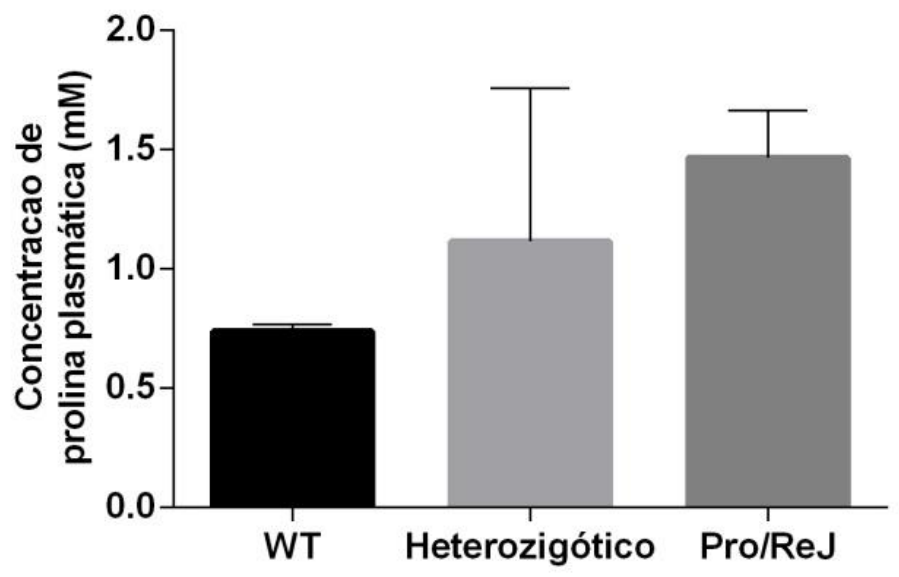

Figura 29 - Concentração de prolina plasmática em camundongos PRO/ReJ. Para validação dos camundongos PRO/ReJ nascidos foi avaliado a prolinemia dos mesmos, segundo método modificado de Bates et al. (1973). O plasma dilúido 10 vezes em água destilada foi submetido um teste colorimétrico do qual utiliza-se a ninidrina como marcador de prolina, em placa de 96 poços. A leitura foi realizada a $515 \mathrm{~nm} \mathrm{em}$ espectrofotometria. Os valores estão expressos em médias e erros-padrão.

Uma vez validado o modelo de hiperprolinemia, iniciaram-se os ensaios de infecção in vivo. De acordo com a hipótese inicial esperávamos observar maiores quantidades de parasitas circulantes em camundongos mutantes aos compararmos aos selvagens, mas surpreendentemente, observamos o oposto. Houve uma redução na parasitemia de 42,9\% para camundongos machos (Figura 30) e de 76,2\% para fêmeas (Figura 31) da linhagem PRO/ReJ, em relação aos grupos controle (C57BL/6). No entanto, apenas a diferença observada em fêmeas foi estatisticamente significativa, com $p=0,0075$. Foi repetido o ensaio acrescentando-se mais um grupo composto por camundongos heterozigóticos, com valores de prolinemia intermediários entre os WT e os PRO/ReJ. Como pode-ser observado, os resultados foram confirmados (Figura 32). Apesar das diferenças não serem significativas, observamos que a média da parasitemia dos grupos compostos por camundongos heterozigóticos (machos ou fêmeas) foi intermediária aos valores do controle e PRO/ReJ. Esses resultados sugerem que a severidade da infeçcão pelo T. cruzi é alelodependente, quando se trata de camundongos deficientes de PRODH. 


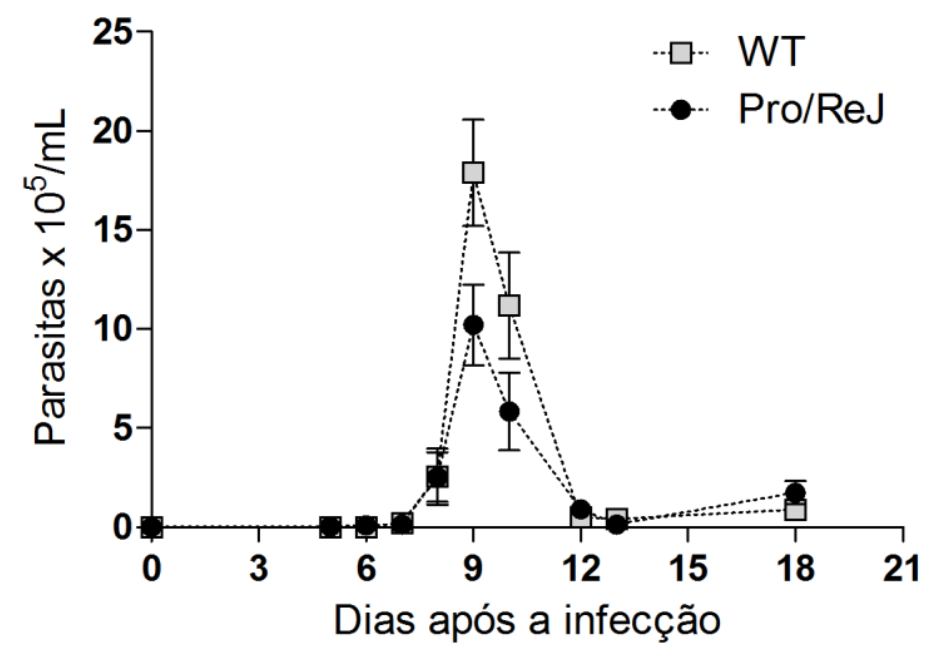

Figura 30 - Acompanhamento da curva de parasitemia em camundongos machos PRO/ReJ. Os animais foram infectados com 1000 formas de tripomastigotas sanguícolas da cepa Y de T. cruzi. A parasitemia foi acompanhada a partir do $5^{\circ}$ ao $18^{\circ}$ d.p.i por meio do método de Brener, 1962 (WT, N=5; Pro/ReJ, N=3). Os valores estão expressos em médias e erros-padrão.

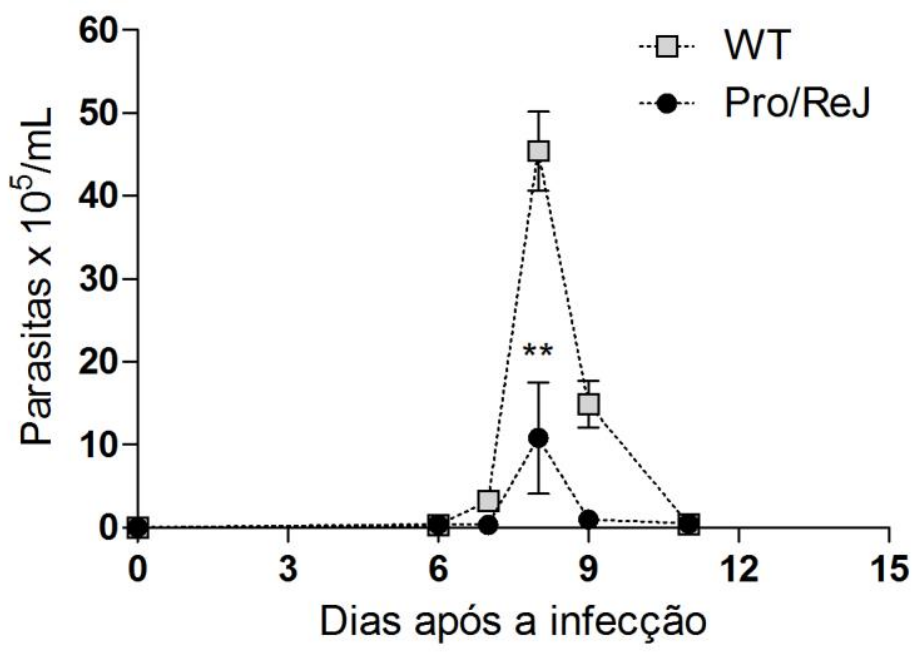

Figura 31 - Acompanhamento da curva de parasitemia em camundongos fêmeas PRO/ReJ. Os animais foram infectados com 1000 formas de tripomastigotas sanguícolas da cepa Y de T. cruzi. A parasitemia foi acompanhada a partir do $6^{\circ}$ ao $11^{\circ}$ d.p.i por meio do método de Brener, 1962. (WT, $\mathrm{N}=4$; Pro/ReJ, $\mathrm{N}=3$ ). Os valores estão expressos em médias e erros-padrão. 


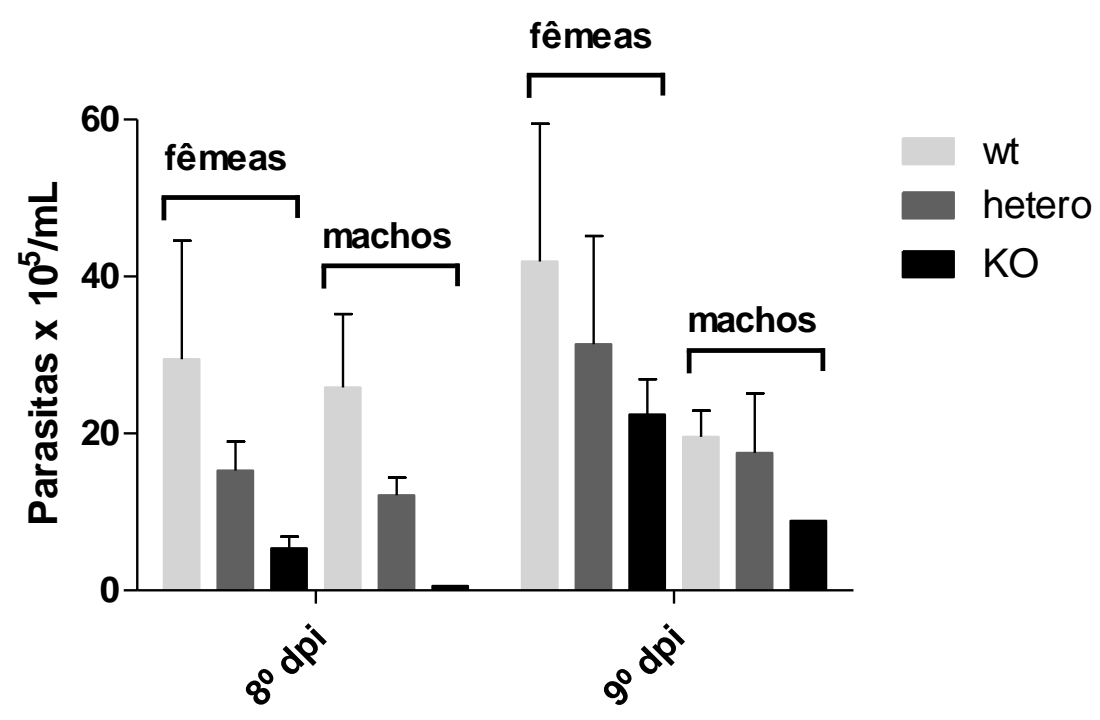

Figura 32 - Picos da curva parasitêmica de camundongos PRO/ReJ e heterozigóticos infectados pela cepa Y de $\boldsymbol{T}$. cruzi. Os animais foram infectados com 1000 formas de tripomastigotas sanguícolas da cepa Y de T. cruzi. A parasitemia foi acompanhada nos picos parasitêmicos por meio do método de Brener (1962). Os valores estão expressos em médias e erros-padrão.

A mortalidade de camundongos PRO/ReJ infectados por $T$. cruzi também foi acompanhada. Como mostrado na Figura 33, fêmeas e machos de camundongos PRO/ReJ apresentaram um aumento drástico na mortalidade quando comparados aos controles. Esses resultados sugerem para $\mathrm{PRO} / \mathrm{ReJ}$ um perfil de resposta pro-inflamatória exacerbada frente a infecção por T. cruzi.

(A)

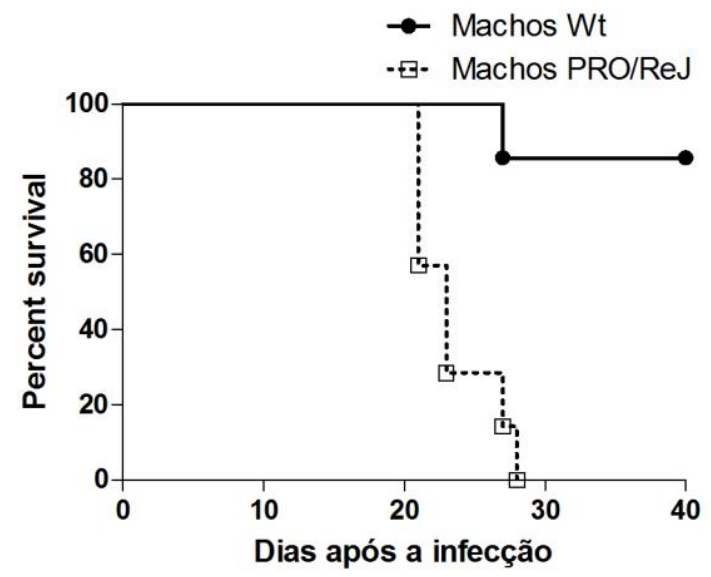

(B)

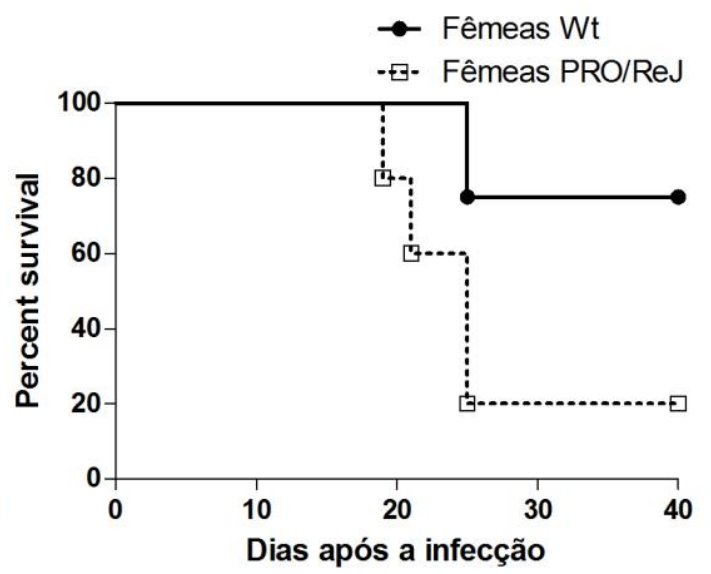

Figura 33 - Curvas de sobrevida de PRO/ReJ fêmeas e machos infectados pela cepa Y de $T$. cruzi. Camundongos nocautes da linhagem PRO/ReJ foram infectados via i.p com 1000 formas de tripomastigotas sanguícolas. A sobrevida foi acompanhada durante 40 dias após a infecção. Os valores estão expressos em médias e erros-padrão. 


\subsection{A prolinemia pode estar relacionada à severidade da sintomatologia de pacientes chagásicos?}

A doença de Chagas pode gerar em pacientes infectados uma sintomatologia principalmente que inclui cardiopatia e distúrbios gastrointestinais. Eventualmente pacientes infectados também podem entrar em um quadro indeterminado do qual não existem sintomas específicos. Existem vários graus de cardiopatia chagásica, do qual divide-se em leve, moderada ou severa (revisado por Boscardin et al., 2010; Marin Neto et al., 1999; Moncayo, Ortiz Yanine, 2006). Numa tentativa de averiguar se a severidade da sintomatologia da doença de Chagas está associada aos níveis de prolina circulante no hospedeiro, nós avaliamos a prolinemia em diferentes grupos de pacientes chagásicos com diferentes graus de cardiopatia chagásica. Observou-se que, pacientes que possuem cardiopatia severa apresentam nívéis reduzidos de prolina sérica quando comparados ao grupo controle (pacientes não infectados) (Figura 34, Tabela 4). A diferença observada foi de $14,1 \%$ sendo ela estatisticamente significativa. Apesar de ter sido observada uma relação inversa entre os níveis de prolina e o aumento da severidade do quadro clínico, as diferenças observadas não foram estatisticamente significativas entre os grupos controle, pacientes indeterminados e com cardiopatia leve/moderada. 
Tabela 4 - Dados estatísticos dos níveis de prolina sérica em pacientes chagásicos que possuem ou não cardiopatia. Controle: grupo não infectado; Ind: grupo indeterminado; L/M: cardiopatia leve e moderada; Sev: cardiopatia severa; IC: Intervalo de confiança; KS: Kolmogorov-Smirnov.

\begin{tabular}{lllll} 
& Controle & Ind & L/M & Sev \\
Tamanho da amostra & 28 & 28 & 27 & 30 \\
\hline Minimo & & & & \\
Percentil 25\% & 0,7880 & 0,6020 & 0,6030 & 0,5200 \\
Mediana & 1,005 & 0,8480 & 0,8560 & 0,8413 \\
Percentil 75\% & 1,171 & 1,031 & 1,025 & 0,9810 \\
Máximo & 1,290 & 1,133 & 1,136 & 1,202 \\
& 1,519 & 1,468 & 1,464 & 1,350 \\
\hline Percentil 10\% & & & & \\
Percentil 90\% & 0,8544 & 0,7888 & 0,6982 & 0,5623 \\
& 1,422 & 1,364 & 1,354 & 1,324 \\
\hline Média & & & & \\
Devio-padrão & 1,153 & 1,026 & 1,018 & 0,9900 \\
Erro-padrão & 0,1895 & 0,2113 & 0,2219 & 0,2467 \\
\hline Limite inferior do IC 95\% da média & 1,080 & 0,9439 & 0,9299 & 0,8979 \\
Limite superior do IC 95\% da média & 1,227 & 1,108 & 1,106 & 1,082 \\
\hline Teste de normalidade KS (distância) & 0,07217 & 0,09859 & 0,1121 & 0,1301 \\
Valor de p & $>0,10$ & $>0,10$ & $>0,10$ & $>0,10$ \\
Passou no teste de normalidade (a=0.05)? & sim & sim & sim & sim \\
\hline Soma & 32,29 & 28,72 & 27,48 & 29,70 \\
\hline & & 0,03993 & 0,04271 & 0,04505
\end{tabular}

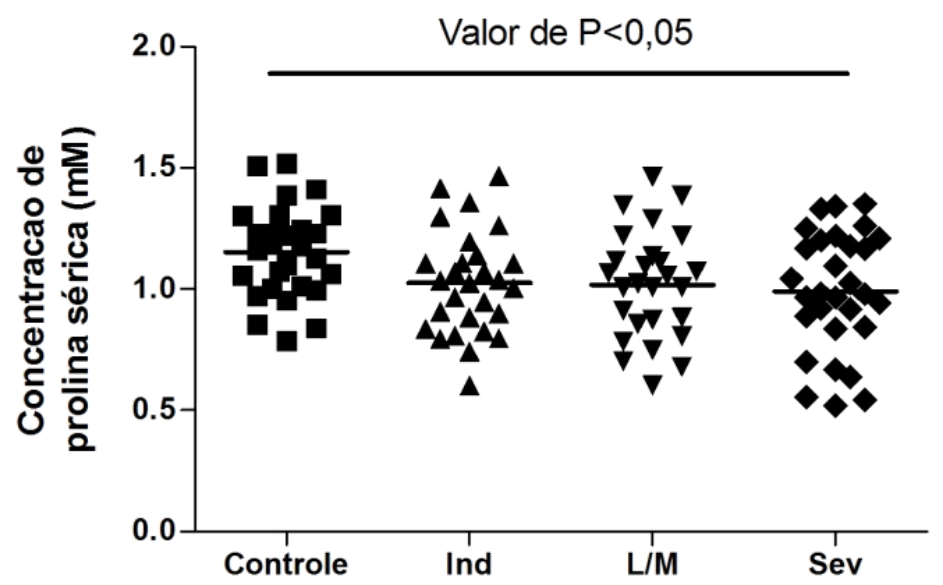

Grupo de pacientes

Figura 34 - Concentração de prolina sérica em pacientes chágasicos. Os soros de pacientes chagásicos com diferentes graus de cardiopatia chagásica foram submetidos a um teste colorimétrico do qual utiliza-se a ninidrina como marcador de prolina, em placa de 96 poços (modificado a partir de Bates et al., 1973). A leitura foi realizada a $515 \mathrm{~nm}$ em espectrofotometria (Ind: pacientes indeterminados; L/M: cardiopatia leve e moderada; Sev: cardiopatia severa). Os valores estão expressos em médias e erros-padrão. 
Todos esses dados juntos colocam a prolinemia no hospedeiro como um fator de severidade para doença de Chagas. 


\section{DISCUSSÃO}

A partir de informações prévias da literatura, durante a infecção das células do hospedeiro mamífero pelo T. cruzi acontece um "switch" metabólico de um metabolismo baseado no consumo de glicose (tripomastigotas) para um metabolismo baseado no consumo de prolina (amastigotas e epimastigotas intracelulares). Ainda segundo a literatura, isto aconteceria em função dos metabólitos oxidáveis disponíveis majoritariamente no sangue (glicose) e no meio intracelular (prolina, dentre outros). Consistente com esta idéia, as formas amastigotas que residem no citoplasma da célula do hospedeiro mamífero apresentam baixa ou nula atividade de transporte de glicose e de prolina. Porém, os maiores níveis de prolina intracelular estão presentes nos amastigotas, sugerindo que a prolina estocada é uma fonte de energia relevante nessa fase do ciclo infectivo (Silber et al., 2009). Já as formas epimastigotas intracelulares apresentam seus estoques de prolina intracelular diminuídos, porém, apresentam a maior taxa de transporte de prolina entre todas formas analisadas (Figura 35). Segundo Tonelli et al. (2004) e Silber et al. (2009) é provável que as formas amastigotas gastem todo o seu estoque para replicação e que epimastigotas intracelulares sejam dependentes da quantidade de prolina livre no citoplasma da célula hospedeira para se replicar e diferenciar para tripomastigotas. Além disso, Tonelli et al. (2004) também mostraram que a suplementação de prolina no meio de cultura aumentou significantemente a eclosão de tripomastigotas das células $\mathrm{CHO}-\mathrm{K}_{1}$ infectadas com a cepa de $T$. cruzi $\mathrm{CL}_{14}$, o que confirma seu efeito no ciclo intracelular.

A partir desses dados, construiu-se a hipótese de que uma concentração aumentada de prolina favoreceria o desenvolvimento da infecção pelo T. cruzi no hospedeiro mamífero. Sobre essa base, resolveu-se elaborar e validar um modelo murino de hiperprolinemia. 


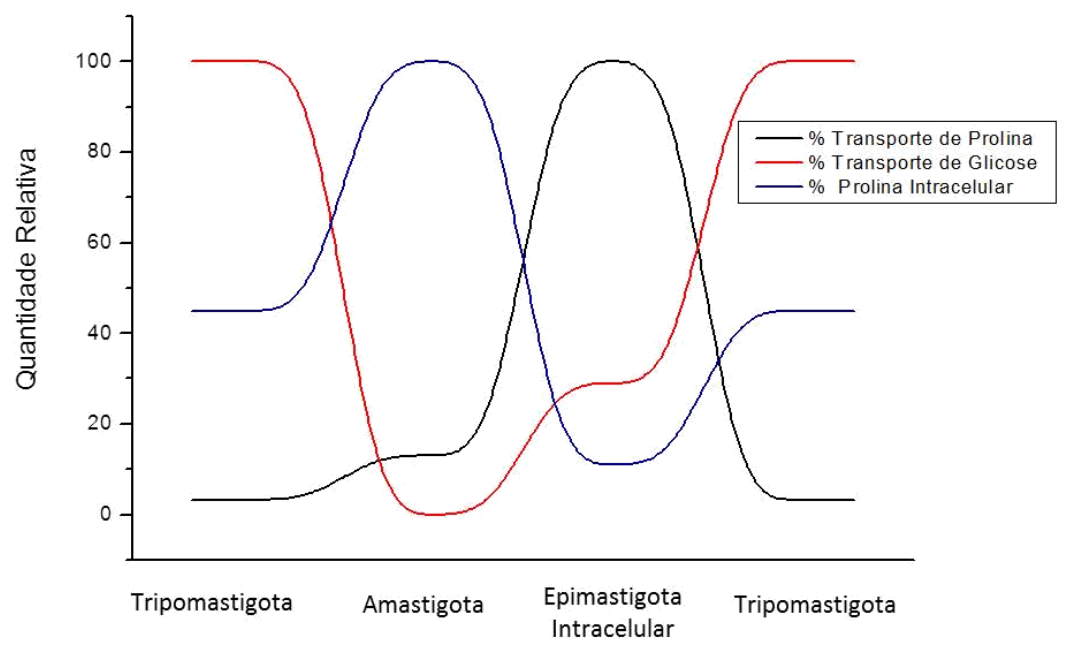

Figura 35 - Variações relativas das atividades dos transportadores de glicose e prolina e as concentrações de prolina intracelular livre durante o ciclo de vida do $\boldsymbol{T}$. cruzi. Fonte: Silber et al. ( 2009).

\subsection{Modelo de hiperprolinemia transiente}

O primeiro objetivo do projeto foi elaborar e validar um modelo murino de hiperprolinemia. Para isso foram realizadas várias tentativas de aumento artificial dos níveis de prolina sanguínea. A primeira estratégia consistiu em injetar prolina por via intraperitoneal em camundongos das linhagens BALB/c e C57BL/6, e acompanhar uma possível variação nos seus níveis plasmáticos do aminoácido. As análises mostraram que em duas horas após a injeção, os níveis de prolina retornaram a valores fisiológicos. Por conta disso, nomeamos o modelo que obtivos aqui como um "modelo de hiperprolinemia transiente". Interessantemente, a injeção de 18,2 $\mu$ mloes/g não apresentou indícios de toxicidade. Esses resultados obtidos aqui corroboram com os dados de farmacocinética segundo Moreira et al. (1989). Esses autores administraram prolina por via subcutânea em ratos da linhagem Wistar com diferentes idades. Eles mostraram que o pico da concentração plasmática nos ratos ocorreu 60 minutos após a injeção, no entanto, em 3 horas os valores já estavam próximos aos valores fisiológicos considerados normais. A concentração máxima plasmática alcançada em ratos com 4 semanas foi de 12,23 \pm 0,19 mM, 60 minutos após a injeção subcutânea. Os autores também mostraram que quanto mais jovens os animais, maior o tempo de meia-vida $\left(\mathrm{t}^{1 / 2}\right)$ plasmática da prolina (Tabela 5) e consequentemente maiores as concentrações plasmáticas para o mesmo tempo de análise (Moreira et al., 1989). 
Tabela 5 - Parâmetros farmacocinéticos da prolina e doses administradas de acordo com a idade de ratos Wistar.

\begin{tabular}{lcccc}
$\begin{array}{l}\text { Idade } \\
(\text { dias })\end{array}$ & $\begin{array}{c}\mathrm{t}^{1 / 2} \\
(\mathrm{~min})\end{array}$ & $\begin{array}{c}\mathrm{V}_{\mathrm{d}} \\
\left(\mathrm{ml}^{-1}\right)\end{array}$ & $\begin{array}{c}\mathrm{CL}_{\mathrm{p}} \\
\left(\mu 1 . \mathrm{min}^{-1} \cdot \mathrm{g}^{-1}\right)\end{array}$ & $\begin{array}{c}\text { Doses de prolina } \\
\left(\mu \text { moles. }{ }^{-1}\right)\end{array}$ \\
\hline $6-13$ & 102 & 0,64 & 4,4 & 12,8 \\
\hline $14-17$ & 87 & 0,73 & 5,7 & 14,6 \\
$18-21$ & 78 & 0,82 & 7,4 & 16,4 \\
$22-28$ & 66 & 0,91 & 9,0 & 18,2 \\
\hline
\end{tabular}

$\mathrm{t}^{1 / 2}=$ meia vida plasmática; $\mathrm{Vd}=$ volume aparente de distribuição; $\mathrm{CL}_{\mathrm{p}}=$ depuração plamática Fonte: Moreira et al. (1989)

No presente trabalho também foi avaliada a administração de prolina através da água do bebedouro, utilizando um regime ad libitum. Dessa vez, esperava-se que os animais mantivessem os níveis aumentados de prolina plasmática, atingindo um novo valor estacionário de prolinemia ao longo do tempo. No entanto, isso não aconteceu, observandose que os animais que receberam o bebedouro com $500 \mu$ mloes $/ g$ de prolina, apresentaram um sinal de toxicidade (pêlos arrepiados). Já que a prolina, independente da via de administração, é eliminada rapidamente pela urina, o ideal seria estabelecer e validar um modelo hereditário de hiperprolinemia (genético e fenotípico). De acordo com a literatura, dois tipos de desordens metabólicas afetam os níveis de prolina plasmática. As hiperprolinemias (HP) tipo I e tipo II são desordens autossômicas recessivas decorrentes de deficiências das enzimas prolina desidrogenase e $\Delta$-pirrolina-5-carboxilato desidrogenase (Efron, 1966; Mitsubuchi et al., 2008). Interessantemente, foi desenvolvida uma linhagem de camundongos, PRO/Re, que apresenta deficiência da prolina desidrogenase e, portanto, sete vezes mais a concentração de L-prolina plasmática (Blake, Russel, 1972). Dado que esse parecia ser o modelo ideal, e que está disponível comercialmente, foi incorporado ao estudo.

\subsection{O efeito da hiperprolinemia transiente sobre a severidade da infeçcão pelo $T$. cruzi}

No modelo de hiperprolinemia transiente não foi encontrado um efeito consistente do aminoácido sobre a severidade da infecção. Porém, no presente trabalho também foi avaliado o efeito da hiperprolinemia transiente sobre a carga parasitária tecidual em diferentes órgãos. Análises histológicas não mostraram uma distribuição homogênea de ninhos de amastigotas no baço e pulmão, sendo muitas vezes, a média dos grupos controle menor que 1 ninho de amastigota em 20 campos microscópicos. Portanto, devido a essas condições, não foi possível a avaliação da carga parasitária nesses dois órgãos utilizando esta técnica. 
Cummings e Tarleton (2003) mostraram que pela técnica de PCR em tempo real é possível detectar mínimas quantidades de parasitas distribuídos em diferentes tecidos de camundongos cronicamente infectados. Portanto, para avaliar de forma mais confiável os dados de carga parasitária em tecidos, foi adaptada do trabalho de Cummings e Tarleton (2003) a técnica de PCR quantitativa. As análises realizadas não mostraram diferenças na carga parasitária entre tecidos provenientes de animais tratados com prolina e grupo controle. Como mencionado anteriormente, nesse modelo, a prolina injetada foi eliminada rapidamente do hospedeiro mamífero. É possível que a grande variabilidade observada nos dados de parasitemia e mortalidade se deva a que, dependendo dos animais, o tempo e/ou concentração plasmatica atingida não seja suficiente para produzir variações significativas nos níveis desse aminoácido dentro das células do hospedeiro e, portanto, ter alguma influência no ciclo intracelular de T. cruzi.

\subsection{O efeito da suplementação de prolina ex vivo no estágio intracelular de T. cruzi}

Como já foi mencionado, existe a possibilidade de que a prolina, embora aumentada de forma transiente no sangue murino, não esteja disponível em quantidades aumentadas para as formas intracelulares de T. cruzi, e isso determinou um efeito não consistente sobre a parasitemia, mortalidade e carga parasitária tecidual. Para avaliar melhor essa possibilidade, partiu-se para ensaios ex vivo, nos quais é mais factível controlar a disponibilidade de prolina no meio intracelular, através da suplementação de prolina no meio de cultura. Células de origem peritoneal foram infectadas e mantidas a diferentes concentrações do aminoácido por 48 ou 72 horas. Ao final deste período a taxa de infecção foi avaliada. Os resultados obtidos não mostraram nenhuma diferença na taxa de infecção (células infectadas/200 células contadas aletorialmente) e na quantidade de amastigotas por células quando tratadas com até $3 \mathrm{mM}$ de prolina. No entanto, chamou a atenção uma redução do volume celular em células tratadas com o aminoácido.

Hu et al. (2007) mostraram que a adição de prolina (a partir de 0,5 mM) no meio de cultura de células de câncer colo-retal linhagem DLD-1, foi suficiente para induzir apopotose mediada pela mitocôndria. Os autores observaram liberação do citocromo c, ativação de caspase 9 , condensação e fragmentação nuclear, e por fim, redução do volume celular. Liu et al. (2005) mostraram que suplementação de prolina no meio de cultura de células DLD-1 que superexpressam a enzima PRODH, induziu a um aumento da geração ROS. Eles mostraram também que, níveis reduzidos de ROS atenuam a resposta apoptótica. 
Nossos resultados junto aos dados da literatura sugerem que em condição de hiperprolinemia, a reação de oxidação da prolina catalisada por PRODH gera ROS em excesso superando desta maneira o limite da capacidade antioxidante da célula e portanto, estimulando a apoptose mediada pela mitocôndria. É possível então, que o tratamento com prolina das células peritoneais tenham dois efeitos paradoxalmente antagônicos: $i$. o aumento da taxa de replicação do parasita dentro da célula hospedeira. ii. a indução de uma resposta que leva à diminuição do volume citoplasmático, o que pode reprimir a replicação desses amastigotas. A resultante desse duplo efeito da prolina sobre o parasita e sobre a célula hospedeira dependeria de um delicado equilíbrio. Além disso, o desencadeamento de um processo apoptótico na célula infectada também poderia interferir com o resultado da infecção.

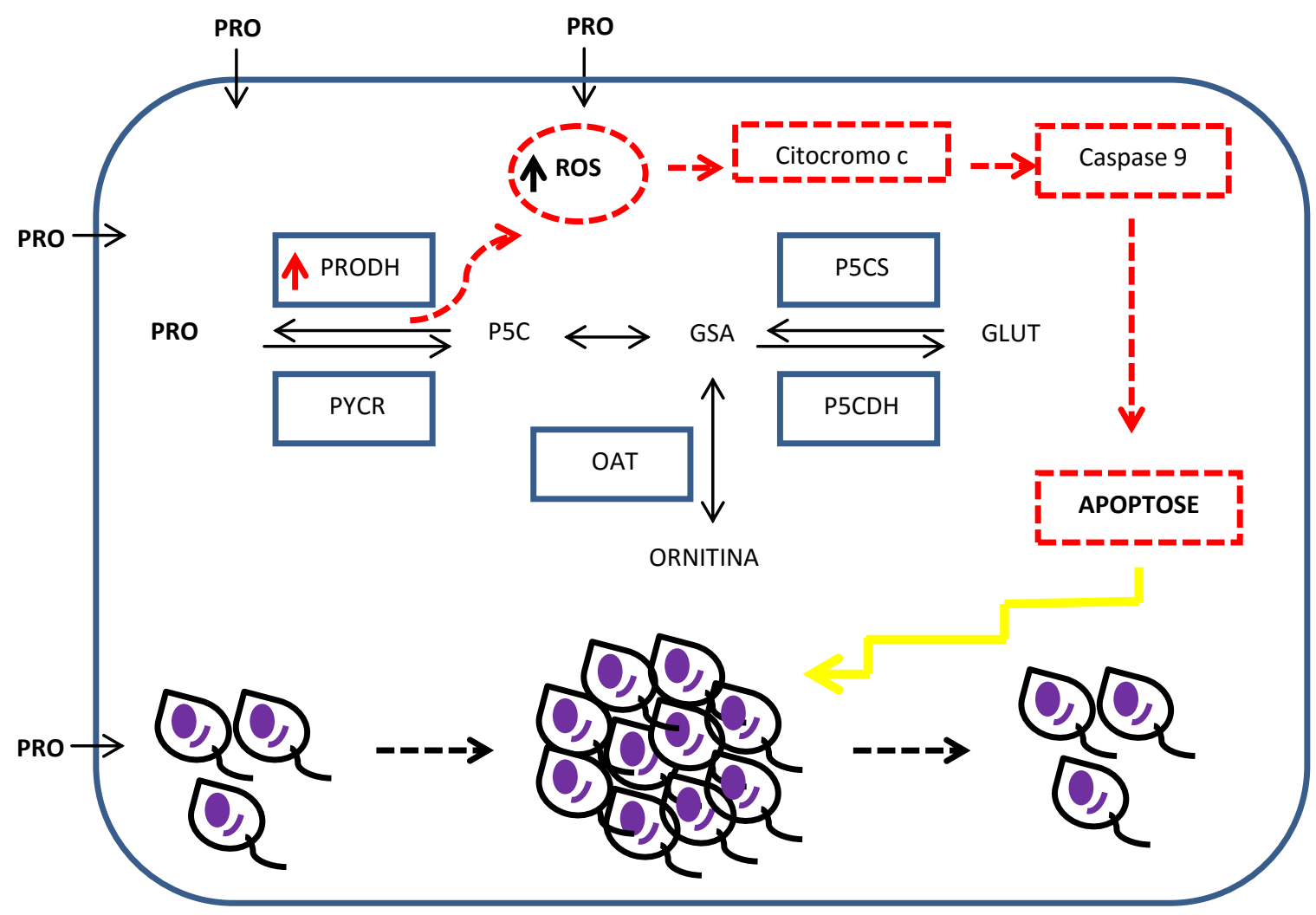

Figura 36 - Representação esquemática sugerida para os efeitos antagônicos do metabolismo da prolina na célula do hospedeiro mamífero sobre infecção pelo $\boldsymbol{T}$. cruzi. $\mathrm{Na}$ presença de concentrações altas de prolina, a reação de oxidação da prolina catalisada por PRODH gera ROS em excesso, e estimula por sua vez, um aumento da apoptose. Esse efeito poderia reprimir a taxa de replicação das formas intracelulares de T.cruzi. Abreviações: PRO, prolina; P5C, $\Delta$ 1-pirrolina-5-carboxilato; GSA, glutamato semialdeído; GLUT, glutamato; PRODH, prolina-desidrogenase; PYCR, P5C redutase; P5CS, P5C sintase; P5CDH, P5C desidrogenase; OAT, ornitina aminotransferase; ROS, espécies reativas de oxigênio. 


\subsection{A prolina e seu papel na imunidade do hospedeiro mamífero}

$\mathrm{O}$ estabelecimento de diferentes modelos experimentais tem permitido estudar a resposta imune e a fisiopatologia da infecção de diferentes cepas de T. cruzi. Mostrou-se que existem variações de virulência tanto entre cepas quanto entre hospedeiros. Sabe-se, por exemplo, que o perfil de expressão de proteases envolvidas na interação com as células do hospedeiro tais como cruzipaína (McKerrow et al., 2006), a expressão de peroxiredoxinas (Piacenza et al., 2008; Pineyro et al., 2008) e a atividade trans-sialidase (Risso et al., 2007) são fatores determinantes da virulência do parasita, e portanto, contribuem a explicar as diferenças observadas entre cepas. Porém, poucos fatores de virulência foram identificados até agora no hospedeiro mamífero (Campbell et al., 2004) sendo que a maior parte deles foram estudados em relação com a imunocompetência dos animais infectados (Boscardin et al., 2010). Como mencionado anteriormente, dados do nosso laboratório permitem inferir que a disponibilidade de L-prolina no hospedeiro mamífero é fundamental para a sua sobrevida. Embora as evidências apontem para L-prolina como fator relevante na biologia de $T$. cruzi, não se descarta a possibilidade da hiperprolinemia, por exemplo, afetar a resposta imune do hospedeiro e por essa via interferir com a severidade da doença. Foi avaliado então, se variações na prolina disponível no meio extracelular estariam envolvidas na variação da produção de moléculas efetoras do sistema imune em células peritoneais. Os resultados obtidos mostraram que a prolina atua como modulador, diminuindo a produção de NO em células peritoneais provenientes de camundongos da linhagem BALB/c, quando ativadas por LPS. No entanto quando as células são estimuladas apenas com infecção, não há diferenças. Além disso, observou-se que viabilidade celular não foi alterada na presença de prolina. Interessantemente, a redução na geração de NO não foi dependente do substrato, arginina, o que indica que a variação prolina-dependente registrada em células ativadas não está relacionada com a disponibilidade de arginina. Em síntese, os resultados obtidos mostram que a redução de NO prolina-dependente não se deve a toxicidade, (o qual refletiria numa redução da densidade celular) e depende do mecanismo de ativação do LPS, mas não da infecção pelo T. cruzi.

Segundo a literatura, um complexo polipeptídico rico-em-prolina (PRP) isolado a partir do colostro bovino mostrou efeitos imunorregulatórios. O PRP possui $25 \%$ de resíduos de prolina e 40\% de aminoácidos hidrofóbicos (Janusz et al., 1981; Janusz, Lisowsky, 1993; Kruzel et al., 2001). Ele induziu a maturação e diferenciação de timócitos murinos afetando a resposta imune celular e humoral in vivo e in vitro (Janusz, Lisowski, 1993; Wieczorek et 
al., 1979; Zimecki et al., 1982), apresentou atividade regulatória sobre a secreção de um gama de citocinas (Zablocka et al., 2001) e inibiu a produção de $\mathrm{NO}^{-} \mathrm{O}_{2}^{-}$liberados em culturas de células estimuladas por LPS (Zablocka et al., 2001; 2005). Ensaios in vivo confirmaram esses resultados (Zabłocka et al., 2005). A fim de confirmar o possível papel imunossupressor da prolina e (se confirmado) testar por qual via a hiperprolinemia estaria imunossuprimindo o hospedeiro, foi avaliada também a expressão gênica de iNOS, TNF- $\alpha$ e e os mediadores anti-inflamatórios IL-10 e TGF- $\beta$ em células peritoneais, estimuladas por LPS e cultivadas na presença de prolina. Os resultados obtidos mostraram a existência de alterações apenas para iNOS, confirmando os dados obtidos para produção de NO. Esses resultados em conjunto confirmam o papel imunossupressor da prolina. No entanto, esse efeito imunossupressor se deve apenas pela regulação da expressão gênica de iNOS, sem alterar o perfil de transcrição de TNF- $\alpha$ e dos mediadores anti-inflamatórios IL-10 e TGF- $\beta$.

\subsection{O transporte de prolina em $T$. cruzi}

Ao longo do seu ciclo de vida, T. cruzi passa por diferentes ambientes tais como o intestino do inseto vetor, circulação sanguínea e citoplasma celular do hospedeiro mamífero (Brener, 1973; Kollien et al., 2001). Entre esses diferentes ambientes, os processos de transporte de metabólitos exógenos, são bastante eficientes e rápidos quando comparado às rotas biossintéticas. TcAAAP é uma família de transportadores de aminoácidos descrita por Young et al. (1999). Em T. cruzi, dois transportadores de prolina foram bioquimicamente caracterizados (Silber et al., 2002) e mais recentemente, os resultados de Sayé et al. (2014) sugerem que TcAAAP069 é a proteína responsável pelo sistema de transporte em epimatigotas, descrito por Silber el al. (2002). Nesse trabalho da literatura, Sayé et al. (2014) também demonstraram que epimastigotas que superexpressam TcAAAP069 apresentam maior taxa de transporte e como consequência, um aumento da concentração de prolina intracelular. Além disso, parasitas transfectados com TcAAAP069 apresentam maior resistência à drogras tripanocidas, o Nifurtimox e o Benzonidazol, e também a espécies reativas de oxigênio incluindo peróxido de hidrogênio e óxido nítrico.

Em colaboração com o grupo de pesquisa que dirige o Prof. Claudio A. Pereira, decidiuse prosseguir com estudos ex vivo e in vivo utilizando tripomastigotas diferenciados a partir de epimastigotas transfectados cedidos (cepas Y e MJL). Aqui foi observado em ensaios ex vivo, que células peritoneais infectadas com formas tripomastigotas da cepa MJL TcAAAP069 apresentaram um aumento significativo da taxa de infecção ao passo que, 
células infectadas com formas tripomastigotas da cepa Y TcAAAP069 apresentaram uma redução na taxa de infecção, quando ambas condições são comparadas ao seus controles respectivos, que expressam a proteína GFP. Infecções in vivo, não mostraram diferenças na parasitemia e mortalidade entre camundongos BALB/c infectados com a cepa Y GFP e Y TcAAAP069. Esses dados sugerem que a redução ou o aumento da taxa de infecção em células peritoneais, em função da superexpressão do transportador de prolina TcAAAP069 e do aumento correlativo da atividade de transporte de prolina, é cepa-dependente.

\subsection{O modelo genético de hiperprolinemia: Camundongos PRO/ReJ}

Como mencionado obtivemos até aqui, um modelo de hiperprolinemia transitória, que denominamos "hiperprolinemia transiente". Como já mencionado, esse modelo foi obtido a partir de injeções diárias de prolina, no entanto, os níveis plasmáticos do aminoácido não se mantém aumentados ao longo do tempo, o que distancia esse modelo do ideal para nosso estudo. Blake e Russell (1972) descreveram uma linhagem de camundongos, PRO/ReJ, deficiente para atividade da enzima prolina desidrogenase (PRODH). Dessa maneira, neste camundongo a prolina acumula-se no sangue pois a mesma não é eficientemente degradada a P5C. Os autores mostraram que camundongos PRO/ReJ conseguem manter os altos níveis de prolina ao longo do tempo, sendo essa diferença de até sete vezes, quando comparado aos camundongos selvagens (C57BL/6). Camundongos PRO/ReJ possuem hiperprolinemia tipo I uma desordem metabólica autossômica recessiva que é decorrente da presença de um alelo anormal localizado no locus designado pro-1 (Blake et al., 1976).

Para iniciar a colônia de camundongos PRO/ReJ, foram adquiridos 2 casais dessa linhagem. Obtiveram-se camundongos heterozigóticos mediantes cruzamentos com camundongos selvagens C57BL/6 provenientes do biotério local. E após retrocruzamentos, conseguiu-se recuperar a linhagem inicial, que apresentavam uma concentração de prolina plasmática duas vezes maior que o controle (dados mostrados nesse trabalho). Segundo a literatura, a diferença esperada era de sete vezes a prolinemia dos animais controle (Blake, Russell, 1972). Após a validação dos lotes de animais puros nascidos, por meio de genotipagem, foram iniciados os experimentos de infecção.

De acordo com a hipótese inicial, esperava-se observar maiores quantidades de parasitas circulantes em camundongos mutantes em comparação com os selvagens. Surpreendentemente, observou-se que camundongos PRO/ReJ apresentaram menor suscetibilidade à parasitemia, com efeito alelo-dependente, no entanto, maior taxa de 
mortalidade (quando comparados aos selvagens). Esses resultados sugerem para PRO/ReJ um perfil de resposta pró-inflamatória exacerbada frente a infecção por T. cruzi. Tal resposta poderia protegê-los contra a infecção e por outro lado gerar danos tissulares graves e a consequente morte por conta da patologia gerada (Abrahamsohn, Coffman 1996; Laucella et al., 1996). Embora o perfil do resultado aponte para essa possibilidade, seriam necessários ensaios adicionais nos quais pudesse ser avaliada a patologia, bem como os infiltrados inflamatórios nos diferentes tecidos afetados.

A prolina desempenha um papel importante na resposta imune. De acordo com a literatura a suplementação de prolina em camundongos infectados pelo circovírus suíno tipo II aumentou significantemente a quantidade de leucócitos, linfócitos, granulócitos circulantes, os níveis séricos de TNF- $\alpha$ e, além disso, diminuiu a carga viral no pulmão quando comparados ao grupo controle (Ren et al., 2013). Duval et al. (1991) mostraram que a prolina participa da proteção de linfócitos contra apoptose estimulando o crescimento celular e promovendo a produção de anticorpos. Em outros organismos a atividade da PRODH desempenha um papel importante na imunidade. Em um trabalho de Ha et al. (2005), foi mostrado que o sistema imune no intestino de drosófilas é prejudicado quando as células intestinais são deficientes de PRODH. Wu (1997) e Wu et al. (2005) também mostraram que a indução do aumento da atividade da PRODH na placenta suína e intestino médio de leitões desempenha um papel protetor nesses orgãos contra infecções no período gestacional e durante o desenvolvimento neonatal. Esses resultados da literatura podem explicar o porquê camundongos $\mathrm{PRO} / \mathrm{ReJ}$ (deficientes da prolina desidrogenase) são mais resistentes a parasitemia.

É importante salientar que outros trabalhos mostraram que a prolina e a PRODH estão envolvidas na proliferação celular, assim como na sobrevivência e autofagia (Phang et al.; 2008a,b, 2010; Zarse et al., 2012). A produção aumentada de espécies reativas de oxigênio na mitocôndria devido ao metabolismo de prolina, leva à ativação da MAP Kinase p38 e Nrf2, e então um aumento da expressão de enzimas antioxidantes e a sobrevida de vermes (Zarse et al., 2012). O papel protetor da prolina também foi mostrado em um trabalho de Obayashi et al. (2012), no qual a administração oral do aminoácido protegeu o fígado de ratos contra hepatite induzida por D-galactosamina por ativar uma via de sinalização de sobrevivência, a IL-6/STAT3. Com base na literatura e em nossos resultados sugerimos um papel protetor para a prolina a favor do hospedeiro infectado por T. cruzi. Alternativamente, a transgenia de camudongos $\mathrm{PRO} / \mathrm{ReJ}$ poderia ter modificado sua imunidade e portanto 
deixando-os mais resistentes à infecção. Para confirmar essa hipótese, seria necessário um estudo de caracterização de sua resposta imune, pois ainda não existe nenhum dado disponível na literatura.

\subsection{Prolinemia versus severidade da infecção}

A variabilidade de sintomas e grau de severidade da doença de Chagas depende de muitos fatores, como cepa do parasita (Espinoza et al., 1998; Vago et al., 2000), a quantidade de T. cruzi que infecta o hospedeiro (Fernández et al., 1996), sua imunidade (Kalil, Cunha-Neto, 1996; Köberle, 1968; Tomlinson, Raper, 1998), seus aspectos nutricionais, o tempo de infecção e possíveis reinfecções (Bustamante et al., 2002; Machado et al., 2001; Revelli et al., 1990). Além disso, a persistência parasitária em locais específicos no hospedeiro infectado induz uma resposta imune local a qual é responsável por danos teciduais, principalmente cardíacos (Kalil, Cunha-Neto, 1996; Kierszenbaum, 1999; Leon, Engman, 2001; Zhang, Tarleton, 1999).

A cardiomiopatia chagásica crônica (CCC) é caracterizada por inflamação, fibrose, miocitólise, vascultite, e persistência parasitária (Tanowitz et al., 1992; Tarleton et al., 2000; Zhang, Tarleton 1999). Existem vários graus de CCC, do qual se dividem em leve, moderada ou severa (revisado por Boscardin et al., 2010; Marin Neto et al., 1999; Moncayo, Ortiz Yanine, 2006). No presente trabalho, foi mostrado em modelo murino que a prolinemia aumentada é capaz de modular a severidade da infecção chagásica. Porém, considerou-se interessante também saber se existe uma correlação (positiva ou negativa) entre a prolinemia e a severidade da infecção em pacientes humanos. Mediante a realização dessa medição em indivíduos não infectados por $T$. cruzi, e pacientes chagásicos assintomáticos, e com CCC severa foi observado que estes últimos apresentam menores níveis de prolina sérica quando comparado a indivíduos não infectados. Esses dados contradizem a hipótese inicial deste estudo. Entretanto, ainda assim foi mostrado que os níveis de prolina circulantes no hospedeiro estão associados à severidade da infecção pelo $T$. cruzi.

A prolidase (E.C.3.4.13.9) é uma exopeptidase citosólica vastamente distribuída em humanos e animais (Myara et al., 1984). A enzima cliva imidodi- e imidotripeptídeos que contenham prolina na região C-terminal ou hidroxiprolina (Mock et al., 1990). Os imidodipeptídeos são obtidos a partir da degradação de procolágenos, colágenos, proteínas 
endógenas e de proteínas provenientes da dieta (Adibi, Mercer, 1973; Jackson, Heininger 1975). Prolidase catalisa o passo final da degradação dessas proteínas e peptídeos a aminoácidos livres dentro do citoplasma. A função biológica primária dessa enzima em mamíferos envolve o metabolismo dos produtos de degradação do colágeno e a reciclagem da prolina a partir de dipeptídeos para a re-síntense do colágeno (Jackson, Heininger, 1975; Yaron, Naider, 1993). Chamson et al. (1989) mostraram que fibroblastos obtidos a partir de indivíduos deficientes de prolidase, apresentavam maior taxa de degradação do colágeno e baixos níveis de prolina em comparação a células controle. Pacientes com CCC, num estágio mais avançado, normalmente apresentam fibrose, a qual é definida pelo acúmulo progressivo de matriz extracellular fibrilar (ECM) no miocárdio. Anormalidades nos fibroblastos levam ao acúmulo da ECM e concentrações elevadas de colágeno. Essas mudanças ocorrem como um mecanismo de cicatrização em resposta ao dano cardíaco crônico causado por uma série de fatores incluindo uma resposta inflamatória intensa (Revisado por Liu, 2011). Colocamos aqui, como hipótese decorrente dos nossos resultados, que é possível que pacientes com CCC severa apresentem menores quantidades de prolina sérica, pois este aminoácido representa o principal substrato para síntese do colágeno destinado para o processo de cicatrização das fibras cardíacas. Dessa forma a quantidade de fibrose presente no miocárdio estaria inversamente relacionada à quantidade de prolina sérica. Uma avaliação da expressão gênica das enzimas que estão envolvidas no metabolismo do colágeno e prolina no coração, seria interessante para responder essa hipótese.

Sobre essa base, esses resultados colocam a prolinemia no hospedeiro como um fator de severidade (virulência) para a infecção pelo $T$. cruzi, e o presente trabalho deixa abertas as possibilidades de se avaliar a prolinemia como preditor da evolução clínica da doença de Chagas. 


\section{CONCLUSÕES}

- A injeção com prolina em camundongos da linhagem BALB/c e C57BL/6 gerou modelos de hiperprolinemia transiente, já que foi eliminada rapidamente pela urina.

- A hiperprolinemia transiente não gerou um efeito consistente sobre a parasitemia, mortalidade ou carga parasitária tecidual, sugerindo que, ao ser eliminado rapidamente pela urina, a concentração plasmática do aminoácido não foi suficiente para influenciar o desenvolvimento intracelular de T. cruzi.

- A suplementação de prolina no meio de cultura não interferiu com a taxa de infecção ou quantidade de amastigotas, no entanto, reduziu o volume de células peritoneais, sugerindo um possível papel apoptótico para prolina.

- A suplementação de prolina no meio de cultura de células peritoneais infectadas reduziu a expressão gênica de iNOS, sendo confirmada pela redução da molécula NO. Este fenômeno foi dependente da ativação por LPS, mas não da infecção pelo $T$. cruzi Não houve alteração do perfil de transcrição de TNF- $\alpha$, IL-10 e TGF- $\beta$. Eses dados sugerem um papel imunossupressor para prolina, via supressão de NO.

- Células infectadas com tripomastigotas MJL TcAAAP069 apresentaram aumento da taxa de infecção enquanto que as infectadas por tripomastigotas Y TcAAAP069 apresentaram diminuição da taxa de infeçção, quando comparadas aos controles, sugerindo que a reposta de redução ou aumento da taxa de infecção ao tratamento com prolina é determinada pela cepa de $T$. cruzi.

- A parasitemia e mortalidade de camundongos infectados pela cepa Y transfectada com TcAAAP069 não apresentaram diferenças com relação ao controle.

- Os níveis plasmáticos de prolina de animais PRO/ReJ foram duas vezes maiores que camundongos C57BL/6 (selvagens), validando dessa maneira o modelo de hiperprolinemia.

- Camundongos hiperprolinêmicos PRO/ReJ infectados apresentaram redução significativa da parasitemia, com efeito alelo-dependente e aumento da mortalidade, comparados ao grupo selvagem. Esses dados sugerem para camundongos PRO/ReJ, um perfil de resposta pró-inflamatória exacerbada frente a infecção por $T$. cruzi, do qual 
controlaria a parasitemia e por outro lado, geraria danos tissuares graves e por fim, adiantamento da morte.

- Pacientes chagásicos com cardiopatia severa apresentaram níveis reduzidos de prolina sérica quando comparados ao grupo não infectado. É possível que pacientes com CCC severa apresentem menores quantidades de prolina sérica, pois este aminoácido representa o principal substrato para síntese do colágeno destinado para o processo de cicatrização das fibras cardíacas, ao qual caracteriza a fibrose.

- Como conlusão final, salientamos que, quando analisados em conjunto, os dados obtidos nesta Tese colocam a prolina como um fator de severidade na infecção pelo $T$. cruzi. 


\section{REFERÊNCIAS*}

Abrahamsohn IA, Coffman RL. Trypanosoma cruzi: IL-10, TNF, IFN-gamma, and IL-12 regulate innate and acquired immunity to infection. Exp Parasitol. 1996;84(2):231-44.

Abel LC, Rizzo LV, Ianni B, Albuquerque F, Bacal F, Carrara D, Bocchi EA, Teixeira HC, Mady C, Kalil J, Cunha-Neto E. Chronic Chagas' disease cardiomyopathy patients display an increased IFN-gamma response to Trypanosoma cruzi infection. J Autoimmun. 2001; Aug 17(1):99-107.

Adad SJ, Andrade DC, Lopes ER, Chapadeiro E. Pathological anatomy of chagasic megaesophagus. Rev Inst Med Trop Sao Paulo. 1991 Nov-Dec;33(6):443-50.

Adams E, Friedman R, Goldstone A. Animal metabolism of hydroxyproline; isolation and enzymic reactions of gamma-hydroxy-hydroxy-glutamic semialdehyde. Biochim Biophys Acta. 1958 Oct;30(1):212-3.

Adams E. Metabolism of proline and of hydroxyproline. Int Rev Connect Tissue Res. 1970. 5:1-91. Review.

Adams E, Frank L. Metabolism of proline and the hydroxyprolines. Annu Rev Biochem. 1980;49:1005-61.

Adibi SA, Mercer DW. Protein digestion in human intestine as reflected in luminal, mucosal, and plasma amino acid concentrations after meals. J Clin Invest. 1973 Jul;52(7):1586-94.

Adl SM, Simpson AG, Farmer MA, Andersen RA, Anderson OR, Barta JR, et al. The new higher level classification of eukaryotes with emphasis on the taxonomy of protists. $J$ Eukaryot Microbiol. 2005 Sep-Oct;52(5):399-451.

Almeida-de-Faria M, Freymuller E, Colli W, Alves MJ. Trypanosoma cruzi: characterization of an intracellular epimastigote-like form. Exp. Parasitol. 1999;92(4):263-7

Alves MJ, Colli W. Trypanosoma cruzi: adhesion to the host cell and intracellular survival. IUBMB Life. 2007;59(4-5):274-79.

Andrade SG, Macêdo V. Combined treatment of Chagas' disease with Bayer 2502 and corticoid (experimental and clinical study). Rev Inst Med Trop São Paulo. 1973 NovDec;15(6):421-30.

Araujo FF, Gomes JA, Rocha MO, Williams-Blangero S, Pinheiro VM, Morato MJ, CorreaOliveira R. Potential role of $\mathrm{CD} 4+\mathrm{CD} 25 \mathrm{HIGH}$ regulatory $\mathrm{T}$ cells in morbidity in Chagas disease. Front Biosci. 2007 May;12:2797-806

*International Committee of Medical Journal Editors. Uniform requirements for manuscripts submitted to biomedical journals. [2011 July 15]. Available from: http://www.nlm.nih.gov/bsd/uniform_requirements.html. 
Bafica A, Santiago HC, Goldszmid R, Ropert C, Gazzinelli RT, Sher A. Cutting edge: TLR9 and TLR2 signaling together account for MyD88-dependent control of parasitemia in Trypanosoma cruzi infection. J Immunol. 2006; 177(6):3515-9.

Bates LS, Waldren RP, Teare ID. Rapid determination of free proline for water-stress studies. Plant Soil. 1973;39:205-7.

Baumgartner MR, Hu CA, Almashanu S, Steel G, Obie C, Aral B, Rabier D, Kamoun P, Saudubray JM, Valle D. Hyperammonemia with reduced ornithine, citrulline, arginine and proline: a new inborn error caused by a mutation in the gene encoding delta(1)-pyrroline-5carboxylate synthase. Hum Mol Genet. 2000;9(19):2853-8.

Benchimol-Barbosa PR. Predictors of mortality in Chagas' disease: the impact of atrial fibrillation and oral transmission on infected population. Int J Cardiol. 2009 Apr; 133(2):275-7.

Bertolo RF, Burrin DG. Comparative aspects of tissue glutamine and proline metabolism. J Nutr. 2008 Oct;138(10):2032-9.

Bice DE, Zeledon R. Comparison of infectivity of strains of Trypanosoma cruzi (Chagas, 1909). J Parasitol. 1970 Aug;56(4):63-7.

Bittencourt AL. Congenital Chagas disease. Am J Dis Child. 1976 Jan;130(1):97-103.

Blake RL, Russell ES. Hyperprolinemia and prolinuria in a new inbred strain of mice, PRORe. Science. 1972;176:809-11.

Blake RL, Hall JG, Russell ES. Mitochondrial proline dehydrogenase deficiency in hyperprolinemic PRO/Re mice: genetic and enzymatic analyses. Biochem Genet. 1976 Oct;14(9-10):739-57.

Bonaldo M, Souto-Padron T, de Souza W, Goldenberg S. Cell-substrate adhesion during Trypanosoma cruzi differentiation. J. Cell Biol. 1988; 106(4):1349-58.

Boscardin SB, Torrecilhas AC, Manarin R, Revelli S, Rey EG, Tonelli RR, Silber AM. Chagas' disease: an update on immune mechanisms and therapeutic strategies. J Cell Mol Med. 2010 Jun;14(6B):1373-84.

Brener Z. Therapeutic activity and criterion of cure on mice experimentally infected with Trypanosoma cruzi. Rev Inst Med Trop Sao Paulo. 1962;4:389-96.

Biology of Trypanosoma cruzi. Annu. Rev. Microbiol. 1973;27:347-82.

Brener Z, Chiari E. Variações morfológicas observadas em diferentes amostras de Trypanosoma cruzi. Ver. Inst. Med. Trop. São Paulo. 1963;5:220-4.

Brener Z, Gazzinelli RT. Immunological control of Trypanosoma cruzi infection and pathogenesis of Chagas' disease. Int Arch Allergy Immunol. 1997;114(2):103-10. 
Brunet LR. Nitric oxide in parasitic infections. Int Immunopharmacol. 2001 Aug;1(8):145767. Review.

Brunton JA, Baldwin MP, Hanna RA, Bertolo RF. Proline supplementation to parenteral nutrition results in greater rates of protein synthesis in the muscle, skin, and small intestine in neonatal Yucatan miniature piglets. J Nutr. 2012 Jun;142(6):1004-8.

Bustamante JM, Rivarola HW, Fernández AR, Enders JE, Fretes R, Palma JA, Paglini-Oliva PA.Trypanosoma cruzi reinfections in mice determine the severity of cardiac damage. Int $\mathbf{J}$ Parasitol. 2002 Jun 15;32(7):889-96.

Camargo EP. Growth and differentiation in Trypanosoma cruzi. I. Origin of Metacyclic Trypanosomes in liquid media. Rev Inst Med Trop Sao Paulo. 1964 May-Jun;6:93-100.

Camargo MM, Almeida IC, Pereira ME, Ferguson MA, Travassos LR, Gazzinelli RT. Glycosylphosphatidylinositol-anchored mucin-like glycoproteins isolated from Trypanosoma cruzi trypomastigotes initiate the synthesis of proinflammatory cytokines by macrophages. J Immunol. 1997 Jun;158(12):5890-901.

Campbell DA, Westenberger SJ, Sturm NR. The determinants of Chagas disease: connecting parasite and host genetics. Curr Mol Med. 2004;4(6):549-62.

Campos, MA, Gazzinelli RT. Trypanosoma cruzi and its components as exogenous mediators of inflammation recognized through Toll-like receptors. Mediators Inflamm. 2004;13(3):139-43.

Cannata JJ, Cazzulo JJ. The aerobic fermentation of glucose by Trypanosoma cruzi. Comp Biochem Physiol B. 1984;79(3):297-308.

Cardillo F, Postol E, Nihei J, Aroeira LS, Nomizo A, Mengel J. B cells modulate T cells so as to favour T helper type 1 and CD8+ T-cell responses in the acute phase of Trypanosoma cruzi infection. Immunology. 2007;122(4):584-95.

Cardoni RL, Rottenberg ME, Segura EL. Increased production of reactive oxygen species by cells from mice acutely infected with Trypanosoma cruzi. Cell Immunol. 1990 Jun;128(1):11-21

Castro MAP, Brener Z. Estudo parasitológico e anátomo-patológico da fase aguda da doença de Chagas em cães inoculados com duas diferentes cepas do Trypanosoma cruzi. Rev. Soc. Bras. Med. Trop. 1985;36:233-9.

Cazzulo JJ. Aerobic fermentation of glucose by trypanosomatids. Faseb J. 1992;6 (13):315361.

Intermediate metabolism in Trypanosoma cruzi. J. Bioenerg. Biomembr. 1994; 26 (2):157-65.

Cerra FB, Caprioli J, Siegel JH, McMenamy RR, Border JR. Proline metabolism in sepsis, cirrhosis and general surgery. The peripheral energy deficit. Ann Surg. 1979 Nov;190(5):577-86. 
Cerisola JA, Neves da Silva N., Prata A., Schenone H., Rohwedder R. Evaluation of the efficacy of nifurtimox in chronic human chagasic infection by using xenodiagnosis (author's transl)]. Bol Chil Parasitol. 1977 Jul-Dec;32(3-4):51-62

Chagas C. Nova tripanozomiaze humana."Estudos sobre a morfolojia e o ciclo evolutivo do Schizotrypanum cruzi n. gen. n. sp, ajente etiolójico de nova entidade mórbida do homem". Mem Inst Oswaldo Cruz. 1909;1:159-218.

Chamond N, Gregoire C, Coatnoan N, Rougeot C, Freitas-Junior LH, da Silveira JF, Degrave WM, Minoprio P. Biochemical characterization of proline racemases from the human protozoan parasite Trypanosoma cruzi and definition of putative protein signatures. J. Biol. Chem. 2003;278(18):15484-94.

Chamond N, Goytia M, Coatnoan N, Barale JC, Cosson A, Degrave WM, Minoprio P. Trypanosoma cruzi proline racemases are involved in parasite differentiation and infectivity. Mol. Microbiol. 2005;58(1):46-60.

Chamson A, Voigtländer V, Myara I, Frey J. Collagen biosynthesis anomalies in prolidase deficiency: effect of glycyl-L-proline on the degradation of newly synthesized collagen. Clin Physiol Biochem. 1989;7(3-4):128-36.

Chatelain E. Chagas disease drug discovery: toward a new era. J Biomol Screen. 2015; Jan;20(1):22-35.

Clemmons JJ. Proline metabolism, collagen formation, and lathyrism. Fed Proc. 1966 MayJun;25(3):1010-5.

Contreras VT, Salles JM, Thomas N, Morel CM, Goldenberg S. In vitro differentiation of Trypanosoma cruzi under chemically defined conditions. Mol. Biochem. Parasitol. 1985;16 (3):315-27.

Coura JR. Contribution to the study of Chagas' disease in the state of Guanabara. Rev Bras Malariol Doencas Trop. 1966 Jan-Mar;18(1):9-98.

Coura JR, Viñas PA. Chagas disease: a new worldwide challenge. Nature. 2010 Jun 24;465(7301):6-7

Cummings K, Tarleton RL. Rapid quantitation of Trypanosoma cruzi in host tissue by realtime PCR. Mol Biochem Parasitol. 2003;129(1):53-9.

Cunha-Neto E, Nogueira LG, Teixeira PC, Ramasawmy R, Drigo SA, Goldberg AC, Fonseca SG, Bilate AM, Kalil J. Immunological and non-immunological effects of cytokines and chemokines in the pathogenesis of chronic Chagas disease cardiomyopathy. Mem Inst Oswaldo Cruz. 2009 Jul;1:252-8.

Cunha-Neto E, Chevillard C. Chagas disease cardiomyopathy: immunopathology and genetics. Mediators Inflamm. 2014;2014:683230 
d'Avila Reis D, Lemos EM, Silva GC, Adad SJ, McCurley T, Correa-Oliveira R, Machado CR. Phenotypic characterization of the inflammatory cells in chagasic megaoesophagus. Trans R Soc Trop Med Hyg. 2001 Mar-Apr;95(2):177-8.

da Silveira AB, Arantes RM, Vago AR, Lemos EM, Adad SJ, Correa-Oliveira R, D'Avila Reis D. Comparative study of the presence of Trypanosoma cruzi kDNA, inflammation and denervation in chagasic patients with and without megaesophagus. Parasitology. 2005 Nov;131(Pt 5):627-34.

da Silveira AB, Chaves AT, de Araújo FF, Silva Gomes JA, Correa-Oliveira R, Toshio Fujiwara R, Ribeiro Freitas MA, de Oliveira EC, Neto SG, Luquetti AO, d'Avila Reis D. Expression of caspase-3 in enteric cells is related to development of chagasic megacolon. Hum Pathol. 2009 Apr;40(4):605-6.

De Groote MA, Fang FC. NO inhibitions: antimicrobial properties of nitric oxide. Clin Infect Dis. 1995 Oct;21:162-5. Review.

Dias E. Um ensaio de profilaxia da doença de Chagas. Rio de Janeiro: Imprensa Nacional; 1945. $116 \mathrm{p}$.

Ding AH, Nathan CF, Stuehr DJ. Release of reactive nitrogen intermediates and reactive oxygen intermediates from mouse peritonealmacrophages. Comparison of activating cytokines and evidence for independent production. J Immunol. 1988 Oct 1;141(7):2407-12.

Docampo R. Sensitivity of parasites to free radical damage by antiparasitic drugs. Chem Biol Interact. 1990;73(1):1-27.

Dubner S, Schapachnik E, Riera AR, Valero E. Chagas disease: state-of-the-art of diagnosis and management. Cardiol J. 2008;15(6):493-504.

Duval D, Demangel C, Munier-Jolain K, Miossec S, Geahel I. Factors controlling cell proliferation and antibody production in mouse hybridoma cells: I. Influence of the amino acid supply. Biotechnol Bioeng. 1991 Sep;38(6):561-70.

Efron ML. Disorders of proline and hydroxyproline metabolism. In: Stanbury JB, Wyngaarden JB, Fredrickson DS. (Eds.). The Metabolic Basis of Inherited Disease. New York: McGraw-Hill; 1966. p. 376-92.

Espinoza B1, Vera-Cruz JM, González H, Ortega E, Hernández R. Genotype and virulence correlation within Mexican stocks of Trypanosoma cruzi isolated from patients. Acta Trop. 1998 Jun 15;70(1):63-72.

Fairlamb AH, Opperdoes FR. Carbohydrate metabolism in African trypanosomes, with special reference to the glycosome. In: Morgan MJ. (Ed.). Carbohydrate metabolism in cultured cells. New York: Plenum Publishing Corporation; 1986. p. 183-224

Fang FC. Perspectives series: host/pathogen interactions. Mechanisms of nitric oxide-related antimicrobial activity. J Clin Invest. 1997 Jun 15;99(12):2818-25. Review 
Fernández AR, Enders JE, Rivarola W, Paglini P, Palma JA. Cardiac beta receptors' density or affinity modified by different Trypanosoma cruzi amount. Acta Physiol Pharmacol Ther Latinoam. 1996;46(2):139-43.

Ferreira HD. Clinico-therapeutic trial with benzonidazole in Chagas' disease. Rev Inst Med Trop Sao Paulo. 1976 Sep-Oct;18(5):357-64

Filardi LS, Brener Z. Susceptibility and natural resistance of Trypanosoma cruzi strains to drugs used clinically in Chagas disease. Trans R Soc Trop Med Hyg. 1987;81(5):755-9.

Galvao Da Silva AP, Jacysyn JF, De Almeida Abrahamsohn I. Resistant mice lacking interleukin-12 become susceptible to Trypanosoma cruzi infection but fail to mount a $\mathrm{T}$ helper type 2 response. Immunolog. 2003;108(2):230-7.

Gazzinelli RT, Oswald IP, Hieny S, James SL, Sher A. The microbicidal activity of interferon-gamma-treated macrophages against Trypanosoma cruzi involves an L-argininedependent, nitrogen oxide-mediated mechanism inhibitable by interleukin-10 and transforming growth factor-beta. Eur J Immunol. 1992;22(10):2501-6.

Gogos JA, Santha M, Takacs Z, Beck KD, Luine V, Lucas LR, Nadler JV, Karayiorgou M. The gene encoding proline dehydrogenase modulates sensorimotor gating in mice. Nat Genet. 1999 Apr;21(4):434-9.

Golgher D, Gazzinelli RT. Innate and acquired immunity in the pathogenesis of Chagas disease. Autoimmunity. 2004;37(5):399-409.

Gomes JA, Bahia-Oliveira LM, Rocha MO, Martins-Filho OA, Gazzinelli G, CorreaOliveira R. Evidence that development of severe cardiomyopathy in human Chagas' disease is due to a Th1-specific immune response. Infect Immun. 2003 Mar;71(3):1185-93.

Gordon S. Alternative activation of macrophages. Nat Rev Immunol. 2003 Jan;3(1):23-35. Review.

Ha EM, Oh CT, Bae YS, Lee WJ. A direct role for dual oxidase in Drosophila gut immunity. Science. 2005 Nov 4;310(5749):847-50.

Hagedorn $\mathrm{CH}$, Phang JM. Transfer of reducing equivalents into mitochondria by the interconversions of proline and delta 1-pyrroline-5-carboxylate. Arch Biochem Biophys. 1983 Aug;225(1):95-101.

Hanson WL, Roberson EL. Density of parasites in various organs and the relation to numbers of trypomastigotes in the blood during acute infections of Trypanosoma cruzi in mice. J Protozool. 1974 Oct;21(4):512-7.

Hayasaka S, Saito T, Nakajima H, Takahashi O, Mizuno K, Tada K. Clinical trials of vitamin B6 and proline supplementation for gyrate atrophy of the choroid and retina. $\mathrm{Br} \mathrm{J}$ Ophthalmol. 1985 Apr;69(4):283-90. 
Higuchi ML, De Morais CF, Pereira Barreto AC, Lopes EA, Stolf N, Bellotti G, Pileggi F. The role of active myocarditis in the development of heart failure in chronic Chagas' disease: a study based on endomyocardial biopsies. Clin Cardiol. 1987 Nov;10(11):665-70.

Higuchi ML, De Brito T, Martins Reis M, Barbosa A, Bellotti G, Pereira-Barreto AC, Pileggi F. Correlation between Trypanosoma cruzi parasitism and myocardial inflammatory infiltrate in human chronic chagasic myocarditis: Light microscopy and immunohistochemical findings. Cardiovasc Pathol. 1993 Apr-Jun;2(2):101-6.

Hoff R, Mott KE, Milanesi ML, Bittencourt AL, Barbosa HS. Congenital Chagas's disease in an urban population: investigation of infected twins. Trans R Soc Trop Med Hyg. 1978; 72(3):247-50.

Homsy JJ, Granger B, Krassner SM. Some factors inducing formation of metacyclic stages of Trypanosoma cruzi. J. Protozool. 1989;36 (2):150-3.

Hu CA, Donald SP, Yu J, Lin WW, Liu Z, Steel G, Obie C, Valle D, Phang JM. Overexpression of proline oxidase induces proline-dependent and mitochondria-mediated apoptosis. Molecular and Cellular Biochemistry. 2007;295:85-92.

Idriss HT, Naismith JH. TNF alpha and the TNF receptor superfamily: structure-function relationship(s). Microsc Res Tech. 2000 Aug 1;50(3):184-95.

Iyengar R, Stuehr DJ, Marletta MA. Macrophage synthesis of nitrite, nitrate, and Nnitrosamines: precursors and role of the respiratory burst. Proc Natl Acad Sci USA. 1987 Sep;84(18):6369-73.

Jackson SH, Heininger JA. Proline recycling during collagen metabolism as determined by concurrent 18O2-and 3H-labeling. Biochim Biophys Acta. 1975 Feb 13;381(2):359-67.

James SL. Role of nitric oxide in parasitic infections. Microbiol Rev. 1995 Dec;59(4):53347. Review.

Janusz M, Starościk K, Zimecki M, Wieczorek Z, Lisowski J.Chemical and physical characterization of a proline-rich polypeptide from sheep colostrum. Biochem J. 1981 Oct $1 ; 199(1): 9-15$.

Janusz M, Lisowski J. Proline-rich polypeptide (PRP) an immunomodulatory peptide from ovine colostrum. Arch Immunol Ther Exp (Warsz). 1993;41(5-6):275-9.

Kalil J, Cunha-Neto E. Autoimmunity in chagas disease cardiomyopathy: Fulfilling the criteria at last?. Parasitol Today. 1996 Oct;12(10):396-9.

Kierszenbaum F. Protection of congenitally athymic mice against Trypanosoma cruzi infection by passive antibody transfer. J Parasitol. 1980;66(4):673-5.

Kierszenbaum F. Chagas' disease and the autoimmunity hypothesis. Clin Microbiol Rev. 1999 Apr;12(2):210-23. Review. 
Kirchhoff LV. Epidemiology of American trypanosomiasis (Chagas disease). Adv Parasitol. 2011;75:1-18.

Köberle F. Chagas' disease and Chagas' syndromes: the pathology of American trypanosomiasis. Adv Parasitol. 1968;6:63-116.

Kollien AH, Grospietsch T, Kleffmann T, Zerbst-Boroffka I, Schaub GAIonic composition of the rectal contents and excreta of the reduviid bug Triatoma infestans. J Insect Physiol. $2001 \mathrm{Jul}$;77(7):739-47.

Krettli AU, Brener Z. Protective effects of specific antibodies in Trypanosoma cruzi infections. J Immunol. 1976;116 (3):755-60.

Kumar S, Tarleton RL. The relative contribution of antibody production and CD8+ T cell function to immune control of Trypanosoma cruzi. Parasite Immunol. 1998;20(5):207-16.

Kruzel ML, Janusz M, Lisowski J, Fischleigh RV, Georgiades JA.Towards an understanding of biological role of colostrinin peptides. J Mol Neurosci. 2001 Dec;17(3):379-89.

Landfear SM. Drugs and transporters in kinetoplastid protozoa. Adv Exp Med Biol. 2008;625:22-32. Review.

Tanowitz HB, Kirchhoff LV, Simon D, Morris SA, Weiss LM, Wittner M. Chagas' disease. Clin Microbiol Rev. 1992 Oct;5(4):400-19. Review.

Laucella SA, Rottenberg ME, de Titto EH .Role of cytokines in resistance and pathology in Trypanosoma cruzi infection. Rev Argent Microbiol. 1996 Apr-Jun;28(2):99-109. Review.

Leon JS, Engman DM. Autoimmunity in Chagas heart disease. Int $\mathrm{J}$ Parasitol. 2001 May;31(5-6):555-61. Review.

Liu Y. Cellular and molecular mechanisms of renal fibrosis. Nat Ver Nephrol. 2011 Oct 18;7(12):684-96. Review.

Liu Y, Borchert GL, Donald SP, Surazynski A, Hu CA, Weydert CJ, Oberley LW, Phang JM. MnSOD inhibits proline oxidase-induced apoptosis in colorectal cancer cells. Carcinogenesis. 2005 Aug;26(8):1335-42.

MacMicking J, Xie QW, Nathan C. Nitric oxide and macrophage function. Annu Rev Immunol. 1997;15:323-50. Review.

Machado EM, Fernandes AJ, Murta SM, Vitor RW, Camilo DJ Jr, Pinheiro SW, Lopes ER, Adad SJ, Romanha AJ, Pinto Dias JC. A study of experimental reinfection by Trypanosoma cruzi in dogs. Am J Trop Med Hyg. 2001 Dec;65(6):958-65.

Magdaleno A, Ahn IY, Paes LS, Silber AM. Actions of a proline analogue, L-thiazolidine-4carboxylic acid (T4C), on Trypanosoma cruzi. Plos one. 2009;4(2):e4534.

Mancilla R, Naquira C, Lanas C. Protein biosynthesis in trypanosomidae. II. The metabolic fate of DL-leucine-1-C14 in Trypanosoma cruzi. Exp. Parasitol. 1967;21(2):154-9. 
Mantilla BS, Paes LS, Pral EM, Martil DE, Thiemann OH, Fernández-Silva P, Bastos EL, Silber AM. Role of $\Delta 1$-pyrroline-5-carboxylate dehydrogenase supports mitochondrial metabolism and host-cell invasion of Trypanosoma cruzi. J Biol Chem. 2015 Mar; 290(12):7767-90.

Marin Neto JA, Simões MV, Sarabanda AV. Chagas' heart disease. Arq Bras Cardiol. 1999 Mar;72(3):247-80. Review.

Merry R, Belfield L, McArdle P, McLennan A, Crean S, Foey A. Oral health and pathology: a macrophage account. Br J Oral Maxillofac Surg. 2012 Jan;50(1):2-7.

Ministério da Saúde Brasil. Secretaria de Vigilância em Saúde. Consenso Brasileiro de Doença de Chagas. Rev Soc Bras Med Trop. 2005;38(Supl.III):1-29.

Martins RM, Covarrubias C, Rojas RG, Silber AM, Yoshida N. 2009. Use of L-proline and ATP production by Trypanosoma cruzi metacyclic forms as requirements for host cell invasion. Infect Immun 77 (7):3023-32.

Mazza S, Montaña A, Benitez C, Juzin E. Transmission del "Schizotrypanum cruzi" al niño por leche de la madre con enfermedad de Chagas. Mepra. 1936;28:41-6

McCabe RE, Mullins BT. Failure of Trypanosoma cruzi to trigger the respiratory burst of activated macrophages. Mechanism for immune evasion and importance of oxygenindependent killing. J Immunol. 1990;144(6):2384-8.

McKerrow JH, Caffrey C, Kelly B, Loke P, Sajid M. Proteases in parasitic diseases. Annu Rev Pathol. 2006;1:497-536.

Melo RC, Brener Z. Tissue tropism of different Trypanosoma cruzi strains. J Parasitol. 1978 Jun;64(3):475-82.

Michailowsky V, Silva NM, Rocha CD, Vieira LQ, Lannes-Vieira J, Gazzinelli RT. Pivotal role of interleukin-12 and interferon-gamma axis in controlling tissue parasitism and inflammation in the heart and central nervous system during Trypanosoma cruzi infection. Am J Pathol. 2001;159(5):1723-33.

Mitsubuchi H, Nakamura K, Matsumoto S, Endo F. Inborn errors of proline metabolism. J Nutr. 2008;138(10):2016-20.

Mock WL, Green PC, Boyer KD. Specificity and $\mathrm{pH}$ dependence for acylproline cleavage by prolidase. J Biol Chem. 1990 Nov 15;265(32):19600-5.

Moncayo A, Ortiz Yanine MI. An update on Chagas disease (human American trypanosomiasis). Ann Trop Med Parasitol. 2006 Dec;100(8):663-77.

Morato MJ, Colley DG, Powell MR. Cytokine profiles during experimental Chagas' disease. Braz J Med Biol Res. 1998 Jan;31(1):123-5

Moreira JC, Wannmacher CM, Costa SM, Wajner M. Effect of proline administration on rat behavior in aversive and nonaversive tasks. Pharmacol Biochem Behav. 1989;32(4):885-90. 
Mosmann T. Rapid colorimetric assay for cellular growth and survival: application to proliferation and cytotoxicity assays. J Immunol Methods. 1983 Dec 16;65(1-2):55-63

Murcia L, Carrilero B, Saura D, Iborra MA, Segovia M. Diagnosis and treatment of Chagas disease. Enferm Infecc Microbiol Clin. 2013 Feb;31 Suppl 1:26-34.

Murray HW, Nathan CF. Macrophage microbicidal mechanisms in vivo: reactive nitrogen versus oxygen intermediates in the killing of intracellular visceral Leishmania donovani. J Exp Med. 1999 Feb;189(4):741-6.

Myara I, Myara A, Mangeot M, Fabre M, Charpentier C, Lemonnier A.Plasma prolidase activity: a possible index of collagen catabolism in chronic liver disease. Clin Chem. 1984 Feb;30(2):211-5.

Nathan C, Nogueira N, Juangbhanich C, Ellis J, Cohn Z. Activation of macrophages in vivo and in vitro. Correlation between hydrogen peroxide release and killing of Trypanosoma cruzi. J Exp Med. 1979;149(5):1056-68.

Nathan C, Shiloh UM. Reactive oxygen and nitrogen intermediates in the relationship between mammalian hosts and microbial pathogens. Proc Natl Acad Sci U S A. 2000 Aug; 97(16):8841-8.

Nickell SP, Stryker GA, Arevalo C. Isolation from Trypanosoma cruzi-infected mice of CD8+, MHC-restricted cytotoxic T cells that lyse parasite-infected target cells. J Immunol 1993;150(4):1446-57.

Obayashi Y, Arisaka H, Yoshida S, Mori M, Takahashi M. Proline protects liver from Dgalactosamine hepatitis by activating the IL-6/STAT3 survival signaling pathway. Amino Acids. 2012 Dec;43(6):2371-80.

Paes LS, Suárez-Mantilla B, Zimbres FM, Pral EM, Diogo de Melo P, Tahara EB, Kowaltowski AJ, Elias MC, Silber AM. Proline dehydrogenase regulates redox state and respiratory metabolism in Trypanosoma cruzi. Plos One. 2013 Jul;8(7):e69419.

Pereira CA, Alonso GD, Ivaldi S, Silber A, Alves MJ, Bouvier LA, Flawiá MM, Torres HN. Arginine metabolism in Trypanosoma cruzi is coupled to parasite stage and replication. FEBS Lett. 2002;526(1-3):111-4.

Pereira CA, Alonso GD, Ivaldi S, Silber A, Alves MJ, Torres HN, Flawia MM. Arginine kinase overexpression improves Trypanosoma cruzi survival capability. FEBS Lett. 2003; 554(1-2):201-5.

Pereira PC, Navarro EC. Challenges and perspectives of Chagas disease: a review. J Venom Anim Toxins Incl Trop Dis. 2013 Dec;19(1):34.

Pfaffl MW. A new mathematical model for relative quantification in real-time RT-PCR. Nucleic Acids Res. 2001 May;29(9):e45.

Pflughaupt KW, Brune GG. Hypoprolinemia in Parkinsonism: a case report. Experientia 1971;27(8):908-9. 
Phang JM. The regulatory functions of proline and pyrroline-5-carboxylic acid. Curr Top Cell Regul. 1985;25:91-132.

Phang JM, Hu CA, Valle D. Disorders of proline and hydroxyproline metabolism. In Scriver CR, Sly WS, Valle D. The metabolic and molecular bases of inherited disease. New York: McGraw-Hill; 2001. p. 1821-38.

Phang JM, Yet GC, Scriver CR. Disorders of proline and hydroxyproline metabolism. In: Scriver CR, Beaudet AL, Sly WS, Valle D. Metabolic and Molecular Bases of Inherited Disease. New York: McGraw-Hill; 1995. p. 1015-75.

Phang JM, Donald SP, Pandhare J, Liu Y. The metabolism of proline, a stress substrate, modulates carcinogenic pathways. Amino Acids. 2008 Nov;35(4):681-90.

Phang JM, Pandhare J, Liu Y. The metabolism of proline as microenvironmental stress substrate. J Nutr. 2008 Oct;138(10):2008-15.

Phang JM, Liu W, Zabirnyk O. Proline metabolism and microenvironmental stress. Annu Rev Nutr. 2010 Aug 21;30:441-63

Phang JM, Liu W, Hancock C, Christian KJ. The proline regulatory axis and cancer. Front Oncol. 2012 Jun;2:60.

Piacenza L, Peluffo G, Alvarez MN, Kelly JM, Wilkinson SR, Radi R. Peroxiredoxins play a major role in protecting Trypanosoma cruzi against macrophage- and endogenouslyderived peroxynitrite. Biochem J. 2008;410(2):359-68.

Piccinali RV, Marcet PL, Noireau F, Kitron U, Gürtler RE, Dotson EM. Molecular population genetics and phylogeography of the Chagas disease vector Triatoma infestans in South America. J Med Entomol. 2009 Jul;46(4):796-809.

Pineyro MD, Parodi-Talice A, Arcari T, Robello C. Peroxiredoxins from Trypanosoma cruzi: virulence factors and drug targets for treatment of Chagas disease? Gene. 2008;408 (1-2):45-50.

Rassi A, Amato Neto V, de Siqueira AF, Ferriolli Filho F, Amato VS, Rassi GG, Rassi Junior A. Treatment of chronic Chagas' disease with an association of nifurtimox and corticoid. Rev Soc Bras Med Trop. 2002 Nov-Dec;35(6):547-50.

Rassi Jr A, Dias JC, Marin-Neto JA, Rassi A. Challenges and opportunities for primary, secondary, and tertiary prevention of Chagas' disease. Heart. 2009 Apr;95(7):524-34.

Rassi Jr A, Rassi A, Marin-Neto JA. Chagas disease. Lancet. 2010 Apr;375(9723):1388402.

Rassi Jr A, Rassi A, Marcondes de Rezende J. American trypanosomiasis (Chagas disease). Infect Dis Clin North Am. 2012 Jun;26(2):275-91. 
Reed SG. In vivo administration of recombinant IFN-gamma induces macrophage activation, and prevents acute disease, immune suppression, and death in experimental Trypanosoma cruzi infections. J Immunol. 1988.140(12):4342-7.

Reina-San-Martin B, Degrave W, Rougeot C, Cosson A, Chamond N, Cordeiro-Da-Silva A, Arala-Chaves M, Coutinho A, Minoprio P. A B-cell mitogen from a pathogenic trypanosome is a eukaryotic proline racemase. Nat. Med. 2000;6(8):890-7.

Reis DD, Jones EM, Tostes Jr S, Lopes ER, Gazzinelli G, Colley DG, McCurley TL. Characterization of inflammatory infiltrates in chronic chagasic myocardial lesions: presence of tumor necrosis factor-alpha+ cells and dominance of granzyme A+, CD8+ lymphocytes. Am J Trop Med Hyg. 1993 May;48(5):637-44.

Reis MM, Higuchi Mde L, Benvenuti LA, Aiello VD, Gutierrez PS, Bellotti G, Pileggi F. An in situ quantitative immunohistochemical study of cytokines and IL-2R+ in chronic human chagasic myocarditis: correlation with the presence of myocardial Trypanosoma cruzi antigens. Clin Immunol Immunopathol. 1997 May;83(2):165-72.

Ren W, Wu M, Luo W, Huang R, Yin Y, Li Y, Li T, Yu X. Dietary supplementation with proline confers a positive effect in both porcine circovirus-infected pregnant and nonpregnant mice. Br J Nutr. 2013 Oct;110(8):1492-9.

Ren W, Zou L, Ruan Z, Li N, Wang Y, Peng Y, Liu G, Yin Y, Li T, Hou Y, Wu G. Dietary L-proline supplementation confers immunostimulatory effects on inactivated Pasteurella multocida vaccine immunized mice. Amino Acids. 2013 Sep;45(3):555-61

Revelli S, Berra H, Valenti J, Moreno H, Bernasconi M, Poli H, Morini J. Effect of reinfection on the development of rats infected with Trypanosoma cruzi. Rev Inst Med Trop Sao Paulo. 1990 Jul-Aug;32(4):260-8

Risso MG, Pitcovsky TA, Caccuri RL, Campetella O, Leguizamon MS. Immune system pathogenesis is prevented by the neutralization of the systemic trans-sialidase from Trypanosoma cruzi during severe infections. Parasitology. 2007;134(4):503-10.

Rocha Rodrigues DB, dos Reis MA, Romano A, Pereira SA, Teixeira VdeP, Tostes Jr S, Rodrigues Jr V. In situ expression of regulatory cytokines by heart inflammatory cells in Chagas' disease patients with heart failure. Clin Dev Immunol. 2012;2012:361730.

Rohloff P, Montalvetti A, Docampo R. Acidocalcisomes and the contractile vacuole complex are involved in osmoregulation in Trypanosoma cruzi. J. Biol. Chem. 2004;279 (50):52270-81.

Rohloff P, Rodrigues CO, Docampo R. Regulatory volume decrease in Trypanosoma cruzi involves amino acid efflux and changes in intracellular calcium. Mol. Biochem. Parasitol. 2003;126(2):219-30.

Rottenberg ME, Bakhiet M, Olsson T, Kristensson K, Mak T, Wigzell H, Orn A. Differential susceptibilities of mice genomically deleted of CD4 and CD8 to infections with Trypanosoma cruzi or Trypanosoma brucei. Infect Immun. 1993;61(12):5129-33. 
Rottenberg ME, Sunnemark D, Leandersson T, Orn A. Organ-specific regulation of interferon-gamma, interleukin-2 and interleukin-2 receptor during murine infection with Trypanosoma cruzi. Scand J Immunol. 1993 May;37(5):559-68.

Sabat R, Grütz G, Warszawska K, Kirsch S, Witte E, Wolk K, Geginat J. Biology of interleukin-10. Cytokine Growth Factor Rev. 2010 Oct;21(5):331-44.

Sardinha LR, Elias RM, Mosca T, Bastos KR, Marinho CR, D'Imperio Lima MR, Alvarez JM. Contribution of NK, NK T, gamma delta T, and alpha beta $\mathrm{T}$ cells to the gamma interferon response required for liver protection against Trypanosoma cruzi. Infect Immun. 2006;74(4):2031-42.

Sarhan S, Seiler N. Proline and proline derivatives as anticonvulsants. Gen Pharmacol. 1989; 20(1):53-60.

Sayé M, Miranda MR, di Girolamo F, de los Milagros Cámara M, Pereira CA. Proline modulates the Trypanosoma cruzi resistance to reactive oxygen species and drugs through a novel D, L-proline transporter. Plos One. 2014 Mar 17;9(3):e92028.

Schafer IA, Scriver CR, Efron ML. Familial hyperprolinemia, cerebral dysfunction and renal anomalies occuring in a family with hereditary nephropathy and deafness. N Engl J Med. 1962;267:51-60.

Schmunis GA. Epidemiology of Chagas disease in non-endemic countries: the role of international migration. Mem Inst Oswaldo Cruz. Oct 30;102 Suppl 1:75-85. Erratum in: Mem Inst Oswaldo Cruz. 2007 Dec;102(8):2 p following 1009.

Silber A, Tonelli R, Martinelli M, Colli W, Alves M. 2002. Active transport of L-proline in Trypanosoma cruzi. J. Eukaryot Microbiol. 2007;49(6):441-6.

Silber AM, Colli W, Ulrich H, Alves MJ, Pereira CA Amino acid metabolic routes in Trypanosoma cruzi: possible therapeutic targets against Chagas' disease. Curr. Drug. Targets. Infect. Disord. 2005;5(1):53-64.

Silber A, Tonelli R, Lopes C, Cunha-e-Silva N, Torrecilhas A, Schumacher RI, Colli W, Alves M. Glucose uptake in the mammalian stages of Trypanosoma cruzi. Mol Biochem Parasitol. 2009 Nov;168(1):102-8.

Sylvester D, Krassner SM. Proline metabolism in Trypanosoma cruzi epimastigotes. Comp. Biochem. Physiol. B. 1976;55(3B):443-7.

Strasen J, Williams T, Ertl G, Zoller T, Stich A, Ritter O. Epidemiology of Chagas disease in Europe: many calculations, little knowledge. Clin Res Cardiol. 2014 Jan;103(1):1-10.

Stenger S, Donhauser N, Thüring H, Röllinghoff M, Bogdan C. Reactivation of latent leishmaniasis by inhibition of inducible nitric oxide synthase. J Exp Med. 1996 Apr;183(4):1501-14.

Strecker HJ, Mela P. The interconversion of glutamic acid and proline. Biochim Biophys Acta. 1955 Aug;17(4):580-1 
Takeda K, Akira S. Toll-like receptors. Curr Protoc Immunol Chapter. 2007;14(14)12.

Taliaferro WH, Pizzi T. Connective tissue reactions in normal and immunized mice to a reticulotropic strain of Trypanosoma cruzi. J Infect Dis. 1955 May-Jun;96(3):199-226.

Tarleton RL, Koller BH, Latour A, Postan M. Susceptibility of beta 2-microglobulindeficient mice to Trypanosoma cruzi infection. Nature. 1992;356(6367):338-40.

Tarleton RL, Grusby MJ, Postan M, Glimcher L. H. Trypanosoma cruzi infection in MHCdeficient mice: further evidence for the role of both class I- and class II-restricted T cells in immune resistance and disease. Int Immunol. 1996 Jan;8(1):13-22.

Tarleton RL, Grusby MJ, Zhang L. Increased susceptibility of Stat4-deficient and enhanced resistance in Stat6-deficient mice to infection with Trypanosoma cruzi. J Immunol. 2000 Aug 1;165(3):1520-5.

Tomlinson S, Raper J. Natural human immunity to trypanosomes. Parasitol Today. 1998 Sep;14(9):354-9.

Tonelli RR, Silber AM, Almeida-de-Faria M, Hirata I.Y, Colli W, Alves MJ. L-proline is essential for the intracellular differentiation of Trypanosoma cruzi. Cell. Microbiol. 2004;6 (8):733-41.

Tyler KM, Engman DM. The life cycle of Trypanosoma cruzi revisited. Int. J. Parasitol. 2001;31(5-6):472-81.

Urbina JA. Specific chemotherapy of Chagas disease: relevance, current limitations and new approaches. Acta Trop. 2010 Jul-Aug;115(1-2):55-68.

Vago AR1, Andrade LO, Leite AA, d'Avila Reis D, Macedo AM, Adad SJ, Tostes S Jr, Moreira MC, Filho GB, Pena SD. Genetic characterization of Trypanosoma cruzi directly from tissues of patients with chronic Chagas disease: differential distribution of genetic types into diverse organs. Am J Pathol. 2000 May;156(5):1805-9.

Vespa GN, Cunha FQ, Silva JS. Nitric oxide is involved in control of Trypanosoma cruziinduced parasitemia and directly kills the parasite in vitro. Infect Immun. 1994 Nov;62(11):5177-82.

Vray B, De Baetselier P, Ouaissi A, Carlier Y. Trypanosoma cruzi but not Trypanosoma brucei fails to induce a chemiluminescent signal in a macrophage hybridoma cell line. Infect Immun. 1991;59(9):3303-8.

Wieczorek Z, Zimecki M, Janusz M, Staroscik K, Lisowski J. Proline-rich polypeptide from ovine colostrum: its effect on skin permeability and on the immune response. Immunology. 1979 Apr;36(4):875-81.

Wizel B, Nunes M, Tarleton RL. Identification of Trypanosoma cruzi trans-sialidase family members as targets of protective CD8 ${ }^{+}$TC1 responses. J Immunol. 1997;159(12):6120-30. 
World Health Organization. Research Priorities for Chagas Disease, Human African Trypanosomiasis and Leishmaniasis.WHO - Technical Report Series. 2012; 975

Wu G. Synthesis of citrulline and arginine from proline in enterocytes of postnatal pigs. Am J Physiol. 1997 Jun;272(6 Pt 1):G1382-90.

Wu G, Bazer FW, Datta S, Johnson GA, Li P, Satterfield MC, Spencer TE. Proline metabolism in the conceptus: implications for fetal growth and development. Amino Acids. 2008 Nov;35(4):691-702.

Wu G, Bazer FW, Hu J, Johnson GA, Spencer TE. Polyamine synthesis from proline in the developing porcine placenta. Biol Reprod. 2005 Apr;72(4):842-50.

Yaron A, Naider F. Proline-dependent structural and biological properties of peptides and proteins. Crit Rev Biochem Mol Biol. 1993;28(1):31-81.

Young GB, Jack DL, Smith DW, Saier MH Jr. The amino acid/auxin:proton symport permease family. Biochim Biophys Acta. 1999 Jan;1415(2):306-22.

Zabłocka A, Janusz M, Rybka K, Wirkus-Romanowska I, Kupryszewski G, Lisowski J. Cytokine-inducing activity of a proline-rich polypeptide complex (PRP) from ovine colostrum and its active nonapeptide fragment analogs. Eur Cytokine Netw. 2001 JulSep;12(3):462-7.

Zabłocka A, Janusz M, Macała J, Lisowski J. A proline-rich polypeptide complex and its nonapeptide fragment inhibit nitric oxide production induced in mice. Regul Pept. 2005 Feb $15 ; 125(1-3): 35-9$.

Zarse K, Schmeisser S, Groth M, Priebe S, Beuster G, Kuhlow D, Guthke R, Platzer M, Kahn CR, Ristow M. Impaired insulin/IGF1 signaling extends life span by promoting mitochondrial L-proline catabolism to induce a transient ROS signal. Cell Metab. 2012 Apr 4;15(4):451-65.

Zeledon R. Comparative physiological studies on four species of hemoflagellates in culture. II. Effect of carbohydrates and related substances and some amino compounds on the respiration. J. Parasitol. 1960;46:541-51.

Zhang L, Tarleton RL.Parasite persistence correlates with disease severity and localization in chronic Chagas' disease. J Infect Dis. 1999 Aug;180(2):480-6.

Zilberstein D. Transport of nutrients and ions across membranes of trypanosomatid parasites. Adv. Parasitol. 1993;32:261-91.

Zimecki M, Janusz M, Starościk K, Lisowski J, Wieczorek Z. Effect of proline-rich polypeptide on donor cells in graft-versus-host reaction. Immunology. 1982 Sep;47(1):1417. 